\title{
Beauvoir and Blackness
}

Nous faisons ici le procès des mystifiés et des mystificateurs.

FRANTZ FANON, Peau noire masques blancs ${ }^{1}$

I'll return to some of the critiques of Beauvoir's "ethnocentricity" later. But first, I want to change the conversation by situating Beauvoir in the left context of her time: which is to say, intellectually between Wright and Fanon; and politically, between Europe and America.

\section{1 \\ Two-Way Streets: Richard Wright, Psychology, and Politics}

Beauvoir always acknowledged Richard Wright as a good friend and a key intellectual influence. Margaret Simons's groundbreaking 1997 essay followed her lead, taking up Paul Gilroy's challenge in The Black Atlantic to look at the influence Wright has had on the European thinkers he came into contact with. ${ }^{2}$ Gilroy's overall agenda was first to restore awareness of the Black contribution to modernity, showing that its intellectual ships sailed in both directions, and second to make clear the limitations of a simple kind of Afrocentric Black nationalism, "to demonstrate why the polarisation between essentialist and anti-essentialist theories of black identity has become unhelpful." 3 (There's a parallel to Toril Moi's discussion of a similar impasse with reference to sex and gender.) ${ }^{4}$ In the decades since Gilroy's book appeared, his view seems to have largely won out: see, for instance, Satya Mohanty's call for the study of "alternative modernities," a "disaggregated modernity" - "[c]ultural chauvinism is toxic" — and the work of Duncan McEachern Yoon and others on excavating "Bandung

1 "We here put on trial both those who have been swindled and those who swindled them." Frantz Fanon, Peau noire masques blancs (hereinafter PNMB), 25; Black Skin, White Masks, translated by Charles Lam Markmann (hereinafter BSWM), 17. Throughout this chapter and the chapter that follows, I will give page numbers from Markmann's translations in the Pluto Press edition, and my translations are based on his, but I have made a very large number of changes, some of them significant. This particular passage, for instance, is almost unrecognizable.

2 Margaret Simons, "Richard Wright, Simone de Beauvoir, and The Second Sex."

3 Paul Gilroy, The Black Atlantic, $\mathrm{x}$.

4 Toril Moi, What is A Woman?, especially vi-xvi and 3-21. 
Humanism."5 The motto of the Caribbean Philosophers' Association- "shifting the geography of reason"-is a beautiful way of stating this larger project. As Jane Anna Gordon explained at the Diverse Lineages of Existentialism conference, "to do rigorous work we need to understand the transnational networks our figures worked in."

Working along those lines, then, Simons credits Richard Wright's influence with moving Beauvoir beyond an apolitical consideration of ethics in the "moral period" works. The break between Beauvoir's early philosophical essays and The Second Sex seems less sharp to me (see chapter 3 for discussion of Beauvoir's critique of nationalism and colonialism in Pour une morale de l'ambiguité). But I am otherwise very much in agreement with Simons's view that Wright's analysis helped Beauvoir see and explain the simultaneously free and unfree situation of women. ${ }^{7}$

It's important that Wright offers an account of Blackness that we could call social constructionist, without falling into a purely "humanist" race-neutral position. ${ }^{8}$ Gilroy quotes Wright: "the word Negro in America means something not racial or biological, but something purely social, something made in the United States." ${ }^{\prime 9}$ And yet obviously, for Wright, race remains the central fact of Black lived experience, and those who seek to deny this become, quite literally, crazy. This is very close to Beauvoir's position. ${ }^{10}$ "If woman did not exist, men would have invented her. They did invent her. But she also exists."11

See Columbia University Institute for Comparative Literature and Society, "Bandung $\mathrm{Hu}$ manisms." See also Satya Mohanty, "Literature to Combat Cultural Chauvinism: From Indian Literature to World Literature," and Duncan Yoon, "The Global South and Cultural Struggles: On the Afro-Asia People's Solidarity Organization."

6 Jane Anna Gordon, Opening Plenary, Diverse Lineages of Existentialism conference. St. Louis, Missouri, June 2014.

7 See now also Lori Marso, Politics with Beauvoir: Freedom in the Encounter, 122-47, for a parallel account.

8 The scare quotes around "humanism" are mine, not his - what I mean is that he didn't use "humanism" as an excuse to pretend race, or racism, did not exist.

9 Gilroy, The Black Atlantic, 149, quoted from Richard Wright, White Man, Listen!, 80.

10 "To decline to accept such notions as the eternal feminine, the Black soul, and the Jewish character, is not to deny that Jews, Blacks, women exist today—such a denial would not represent a liberation for those concerned, but rather a flight from reality. It is clear that no woman can claim without bad faith to situate herself beyond her sex." [Refuser les notions d'éternel féminin, d'âme noire, de caractère juif, ce n'est pas nier qu'il y ait des Juifs, des Noirs, des femmes: cette négation ne représente pas pour les intéressés une libération, mais une fuite inauthentique. Il est clair qu'aucune femme ne peut prétendre sans mauvaise foi se situer par-delà son sexe ( $D S$ 1:13).] See chapter 1 above for discussion of this point in a different context.

11 “[S]i [la femme] n'existait pas, les hommes l'auraient inventée. Ils l'ont inventée. Mais elle existe aussi sans leur invention" ( $D S$ 1:303). 
Simons lists a number of other ways Wright importantly influenced Beauvoir's understanding of oppression, including "his subjectivist approach, his critical analysis of the limitations of Marxist ideology ... and his militant engagement." ${ }^{\prime 2}$ She sees Wright as passing on to Beauvoir W. E. B. DuBois's idea of "double consciousness," which served as a model for Beauvoir's concept of women as split and divided against ourselves: both integrated into and alienated from the dominant culture which defines us as defective human beings. She also notes Wright's demystification of "the claims by segregationists that blacks are happy and contented with their naturally inferior place in society" as a parallel to Beauvoir's debunking of myths about women, quoting from L'Amérique au jour le jour 1947: "the famous laughter of blacks ... is often only a mask that the black dons in the presence of whites because he knows that it is demanded of him." ${ }^{13}$ Beauvoir's crucial abandonment of the concept of "happiness" and her choice to speak instead of "freedom," which I discussed in chapter 1 above, may thus rest in part on Wright's analysis, and the illustrations he provides. ${ }^{14}$

Another important confluence between Beauvoir's thinking and Wright's has to do with the specifically psychological account The Second Sex provides of the damage oppression does. Jay Garcia's 2012 book, Psychology Comes to Harlem, has underscored the centrality of psychoanalysis and related versions of psychological and social research to Wright's work as both novelist and activist. When Wright dedicated himself to exposing "the unconscious machinery of race relations' in modern American life," which led ineluctably to violence and might lead to fascism, he seems to have meant "unconscious" in a literally Freudian way. ${ }^{15}$ Like many progressives in the 1940 s, Wright "recognize[d] the field as a resource for alternative and dissident interpretations of the racialized

12 Simons, "Richard Wright," 176. Simons sees Wright's "phenomenological descriptions of black experience of oppression" as an alternative both to Myrdal's social science approach and "the economic reductionism of Marxist orthodoxy," though she notes also that "[h] is critique of liberal individualism is as resounding as his critique of Marxism" $(181)$.

13 Simons, "Richard Wright," 178.

14 "[T] that the situation one wants to impose on him is a happy one: in particular, those who one condemns to stagnation one declares happy, under the pretext that happiness is immobility." [[I]l n'y a aucune possibilité de mesurer le bonheur d'autrui et il est toujours facile de déclarer heureuse la situation qu'on veut lui imposer: ceux qu'on condamne à la stagnation en particulier, on les déclare heureux sous prétexte que le bonheur est immobilité $(D S$ 1:31).]

15 Jay Garcia, Psychology Comes to Harlem:Rethinking the Race Question in Twentieth-Century America, 14. 
social order"; ${ }^{16}$ his collaboration with Fredric Wertham to found the Lafarge Clinic in Harlem showed on a small scale that segregation could be reframed as a "public health problem" without being de-politicized;17 in novels and essays, his analysis of the relationship between frustration and aggression, between fear and rage, diagnosed a sickness that damaged both whites and Blacks and called into question the patriotic idea of America as an ethical ideal. For instance, his introduction to Black Metropolis drew attention to "how any human beings can become mangled, how any personalities can become distorted when men are caught in the psychological trap of being emotionally committed to living a life of freedom that is denied them,"18 and quoted Life magazine's analysis of "Myrdal's notion of dissonance in American consciousness":

The dilemma, of course, is this: the basic tenets of the American creed make all men free and equal in rights. Yet in fact we deny equal rights to our largest minority, and observe a caste system which we not only criticize in other nations but refuse to defend in ourselves. This makes us living liars-a psychotic case among the nations. ${ }^{19}$

When Faulkner, who had encouraged "the Negro" to "go slow" in demanding human rights, won the Nobel Prize in 1950, Wright remarked, "[i]t would be a great mistake to feel that the Negro was the only victim of the white South's proud neurosis." 20

Medical and moral language are inextricable in terms like "neurosis" and "psychotic"; Garcia convincingly traces this discourse through a number of writers who followed Wright (Chester Himes, Lillian Smith, Ralph Ellison, to some extent James Baldwin), and reminds us that the case in Brown v. Board of Education was built largely from expert evidence about the psychological damage done to children by segregation in schools. So from Wright's perspective, and from a mid-century perspective generally, Myrdal's idea of "pathology" seems less problematic than it did to Simons (and might seem to most readers now).

Narrative depictions of psychological dysfunction (glossed as such) in Wright's work might be multiplied almost endlessly_Bigger Thomas in Native

\footnotetext{
16 Ibid., 53 .

17 Wertham said that psychotherapy must be discussed "at this time and at this place" (Garcia, Psychology Comes to Harlem, 62).

18 Richard Wright, "Introduction" to St. Clair Drake and Horace Cayton, Black Metropolis: A Study of Negro Life in a Northern City, xxvi. See Garcia, Psychology Comes to Harlem, 40.

19 Wright, Black Metropolis, 41.

20 Michel Fabre, The World of Richard Wright, 89.
} 
Son is the best-known example. Less melodramatically, in his autobiographical Black Boy Wright describes African Americans "transferring" hatred to other African Americans, and explores problems of "adjustment," "self-hatred," and being at war with reality. Passages like his descriptions of co-workers in a hotel- "how smoothly the black boys acted out the roles that the white race had mapped out for them ... [T] hey knew ... what not to aspire to"21_make it easy to understand why Black Boy was attacked for "negative portrayals" of African American life, even though Wright is describing a mutually reinforcing system: "Whites would rather have had negros who stole, work for them than negros with self-respect." ${ }^{22}$ Reading this, it's hard not to be struck by the similarities to Beauvoir's account of the "feminine" personality formed as a result of male domination, whether directly or through complicity or both-the "negative portrayals" of women for which she, too, was attacked, especially in discussions of her fiction. ${ }^{23}$

But Wright and the others Garcia discusses wrote with an ultimately therapeutic aim. (Even the decision in Brown v. Board can be read that way.) And as I've said in chapter 1 above, Beauvoir was relentlessly opposed to both the formal institution of psychotherapy, and its prevalence as a cultural practiceshe saw it as a quintessentially American project of conformity and normalization. ${ }^{24}$ She would not change her mind about this: the late novel Les belles images puts therapy in parallel with the "reassuring lies" of the Catholic Church and technocratic capitalism, and the dénouement turns on the heroine's

21 Richard Wright, Black Boy, in Later Works, 188.

22 Ibid., 191. See Garcia, Psychology Comes to Harlem, 43.

23 For fuller discussion, see Altman, "Beauvoir as Literary Writer."

24 In this, she was closer to the Jamaican C. L. R. James, who, while, in Garcia's words, "buoyed" by his "wonderful" meeting with Wright, still judged psychoanalytic thought in the modern world not liberatory but "a refuge from social ills" and "found "the football that American intellectuals had made of it' disturbing" (Garcia, Psychology Comes to Harlem, 100). James lived in the United States between 1938 and 1953, after he'd already written The BlackJacobins; his book American Civilization was written quickly, before he was deported. Beauvoir did not read The BlackJacobins until much later.

The irony that "American" psychoanalysis was almost entirely the creation of European émigrés would take entirely too long to follow up here, but it's worth noting, as Garcia does, the importance of Freud to studies of fascism such as Adorno's The Authoritarian Personality which in turn influenced Wright, Wertham, Brown v. Board, etc. Adorno's work of this period also combined what we would call "theory" with empirical social science methodology deployed on a large scale; his psychohistorical exploration of fascism did not prevent criticisms rather similar to Beauvoir's of the negative cultural effects of popular Freudianism from emerging in his Minima Moralia. The methodologies seemed complementary rather than conflicting. See Stefan Müller-Doohm, Adorno: An Intellectual Biography. 
success in resisting "treatment" for her daughter. So, as with her use of Stekel, and of Freudians generally, we could see Beauvoir following Wright's descriptive account but unhooking herself from the prescriptions that follow.

It's easy to trace continuities between Wright's discussion of American pathologies and a term in current use, "historical trauma." (Ta-Nehisi Coates makes this connection: the title of his powerful 2015 book, Between the World and $M e$, is a line from an early poem by Wright.) But the distinction Wright and Beauvoir make between "happy" and "free" is not much heard today. Wright and Beauvoir are both concerned with the psychological damage oppression does, on the level of what we might now call "affect." Affect matters. But the question of who affectively experiences/feels the effect of oppression, and the question "who is oppressed," are distinct questions: while the epistemology of affect is important, it does not block other epistemologies. ${ }^{25}$ That seems to me, for lack of a better term, healthy. As Beauvoir makes clear in Pour une morale de l'ambiguité, situations do occur that pit the need of one oppressed group against another in irreconcilable ways. If the measure of oppression is taken solely in terms of affect, a kind of "race to the bottom" or competition around who feels worse becomes inevitable; even though all the feelings involved may be both authentic and legitimate, the resulting negative spiral can do damage to all concerned, without pointing toward solutions.

We should remember, too, that Bigger Thomas is hardly presented as a moral exemplar: Wright's view included the idea that racism creates criminals, but criminality as such is not glorified or romanticized as "resistance." This seems to me consistent with Beauvoir's refusal to romanticize women damaged by oppression: as I discussed above, for her, the harmed person could not be good, and that was part of the harm.

\section{Lost in Translation}

Simons also points out that by "presenting Wright as her mentor, her guide not only to the sights of Harlem, but to the intellectual terrains of racism, Beauvoir's narrative legitimizes Wright's analysis-perhaps the reason that an American edition of America Day by Day 1947 did not appear until 1953, with

25 Consider this, from White Man, Listen: "Recently a young woman asked me: 'But would your ideas make people happy?' and before I was aware of what I was saying, I heard myself answering with a degree of frankness that I rarely, in deference to politeness, permit myself in personal conversation: my dear, I do not deal in happiness, I deal in meaning" (xxix). 
most of the discussion of Myrdal's text and the passages in which Wright appears to be teaching Beauvoir deleted." ${ }^{26}$ Michael Barber gives more detail:

Although Beauvoir's preoccupation with the anti-black racism she experiences in the United States appears in the first English translation, the translation fails to convey the intensity of her concern since it omits at least fifteen discussions, often pointed, about race relations, including Beauvoir's most extensive reflections on race in the United States, an important account of a visit to an African-American church with Richard Wright, and a rather long discussion of the treatment of AfricanAmericans within the cotton industry in the South. ${ }^{27}$ When one considers these key omissions, including a regular deleting of comments on labor relations, red-baiting, and Truman's foreign policy, with which Beauvoir often introduces her daily entries, one realizes that the English translation has been depoliticized and actually so deformed that it is hardly the same book. ${ }^{28}$

So while it's tempting (and not incorrect) to attribute the deletion of Wright's role to the same American racism he and Beauvoir were both analyzing, I'd argue that's just one part of a broader depoliticization of the texts, a refusal to take political ideas seriously.

This may have been the first such transatlantic "revision" of a Beauvoir text but it was hardly the last. Something similar happened with Les mandarins, Beauvoir's 1954 "condition of France" novel about the post-war period. While the central ethical drama of Les mandarins involves French intellectuals coming to terms with the aftermath of the Second World War, a significant portion of its action unfolds in the United States. Its clearest fictional precursor is John Dos Passos's trilogy, U.S.A.: both books cogently explore the failings of almost every faction on the left, and yet leave us with a sense that a leftist perspective remains urgent, that no other road is possible. Les mandarins was reviewed in the New Republic under the title "Simone Go Home," even though, as Bill McBride has shown, the translation softened its politics to the point of incoherence. (McBride points in particular to the disappearance of the word "hegemony" from Beauvoir's descriptions of post-war American domination. $)^{29}$

\footnotetext{
26 Simons, "Richard Wright," 181; L'Amérique au jour le jour 1947 (hereinafter AJ), 181-82.

27 AJ 231-42, 265-69, 207-10.

28 Barber, "Phenomenology and the Ethical Bases of Pluralism," 161-62.

29 William McBride, "The Conflict of Ideologies in The Mandarins: Communism and Democracy, Then and Now," 33-45. The negative review (Donald Malcolm, "Simone Go
} 
The de-politicized translation of L'Amérique au jour le jour 1947 wasn't the first time a publisher thought Americans were too stupid, or too lazy, to understand the political context and implication of European intellectual work, and it wasn't the last time, either. How many generations of American graduate students devoured Roland Barthes's Mythologies without realizing that something like a third of the original book had been silently deleted, eliminating all the topical references and distorting Barthes's political critique? The lack of cultural and political context that accompanied the importation of Foucault and Derrida led American readers to lump them together as "post-structuralists," to the irritation of both. Another example is the selling of the "New French Feminism" in the 1980 os. $^{30}$ Mistranslations of Fanon's work could hardly conceal that he was a political writer, but with mistakes like changing "l'expérience vécue du noir" to "The Fact of Blackness" Charles Lam Markmann certainly made a Parshley-sized hash of his views. ${ }^{31}$ Fair or unfair, the assumption that "American readers won't get it" has been a self-fulfilling prophecy: the more we receive our "theory" with the politics excised, the less likely we are to understand, or even notice it, when it is there. L'Amérique au jour le jour 1947 diagnosed this problem, as well as falling victim to it. ${ }^{32}$ Beauvoir's frustration that

Home") is cited in the introduction to Sally Scholz and Shannon M. Musset, eds., The Contradictions of Freedom: Philosophical Essays on Simone de Beauvoir's The Mandarins, 22.

See Christine Delphy, "The Invention of French Feminism: An Essential Move," and Claire Moses, "Made in America: 'French Feminism' in Academia."

31 See Nigel Gibson, "Fanon and the Pitfalls of Cultural Studies," and David Macey, Frantz Fanon: A Biography, 25-6. Richard Serrano describes pointing out the mistranslation to a keynote speaker who was using it in a project on "the poetics of Fanon": "The speaker informed me that others had already pointed out these errors to him, but added that he considered the mistranslation of Fanon a crucial part of the text's history" (Against the Postcolonial: Francophone Writers at the End of the French Empire, 174).

32 While the 1998 translation by Carol Cosman restored the cuts, I noticed that all the English-language versions continue to drop "1947" from the title, presumably to increase sales by making the book seem less "dated"; but the result distorts Beauvoir's intentions by implying a more totalizing view: the date implied a more local and direct political "take" on rapidly changing conditions that the writer might hope to influence. (Around the same time Sartre was arguing that engaged writing should be designed to be consumed quickly on the spot, like bananas; if a text became "dated," that was a good sign rather than a problem [What is Literature, 74].) In contrast, a 1969 translation from Buenos Aires is titled Norteamérica al desnudo, which perhaps unbalances Beauvoir's view too far in the other direction.

The cover of the new British paperback edition shows an African-American couple in 1940 s hats sitting on an old-fashioned bus (we see them from the back); but the cover of the newer American edition is a nice picture of a young, rather innocent-looking Simone alone, looking out diagonally over a snowy street that could be anywhere- the same picture appears on La force de l'âge and indeed on a number of books about Beauvoir. The 
hardly anyone in the United States was willing to discuss, for instance, the implications of the atomic bomb, or the rise of McCarthyism, is palpable throughout the long sections about her visits to college campuses: both students and faculty members seem clueless, careerist, cowed, or simply paralyzed by the prevailing conformism.

That The Second Sex also came to American audiences in a significantly truncated and distorted form is well known. But not all of what I'm going on about can be blamed on Parshley or his editors. ${ }^{33}$ Which parts do you assign? Which parts do you skip because "they won't understand it anyway, and it will take too long to explain"? I asked a bunch of reasonably clever college seniors what they already knew about Marx, what associations they had. No one spoke at first; then one of them raised her hand and ventured, "Was he the one who worked on the fish?" (She must have been thinking of Darwin.) Let me be clear: I don't think this was the student's fault.

And you know, Audre Lorde was a woman of the international left, too. When that class of seniors came to read Zami: A New Spelling of My Name, I gave them a reading quiz that included:

- Who were the Rosenbergs?

- When Audre and Ginny ride the bus downtown singing "union songs," what are these?

- Why don't the women in the factory use the protective shields on their machines?

- What is a "speedup"?

- Why is Rhea crying? (Answer: she's a Party member, and they've threatened to exclude her for living with Audre.)

- Why was Eudora living in Mexico? (Answer: she's a journalist, and she's been blacklisted.)

Stopping to explain these things did slow us down in getting to the famous passage about "the very house of difference," but I think it added to their understanding of the book, and of American history.

current French paperback uses Bernice Abbott's dreamy-looking headshot, and in the excerpt on the back cover Beauvoir describes her text as tentative and subjective, and draws attention to her own incompetence. (Ironically, my favorite cover is the one on the 1953 Dudley translation: a stylized design based on the American flag, with one rather lopsided star.)

Anna Bogic ("Uncovering the Hidden Actors with the Help of Latour: The 'Making' of The Second Sex") has painstakingly excavated the archive of correspondence to show Parshley in a more sympathetic light, as having fought unsuccessfully for a better translation than the one we've all been blaming him for. 
And to go back to the "Master's Tools" essay I discussed above: the anthologized version of this piece many of us religiously teach does end, as I said above, with the strong peroration quoting Beauvoir. Interestingly, though, an earlier version of the text exists, and in the earlier version something came $a f$ ter that paragraph. Lorde gave the last word to Aimé Césaire, the revolutionary poet and statesman from Martinique.

Prospero, you are the master of illusion.

Lying is your trademark.

And you have lied so much to me

(Lied about the world, lied about me)

That you have ended by imposing on me

An image of myself.

Underdeveloped, you brand me, inferior,

That is the way you have forced me to see myself

I detest that image! What's more, it's a lie!

But now I know you, you old cancer,

And I know myself as well.

CALIBAN, in AIME CÉSAIRE's A Tempest ${ }^{34}$

Why did the anthology-makers cut this? "Oh, people won't know who Aimé Césaire was." Too right, they won't. And cuts like this are why. ${ }^{35}$

Oh, and then look: the first essay in Sister Outsider is about Lorde's trip to Moscow, where she is pleased to find that the Russian people aren't racist and that health care is provided free. And we don't teach that essay because ... because ... well ... So there is an endless regress here.

34 This version of Lorde's text circulates on-line, with the source given as follows: Lorde, Audre. "The Master's Tools Will Never Dismantle the Master's House." 1984. Sister Outsider: Essays and Speeches. Ed. Berkeley, CA: Crossing Press. 110-14. 2007. Print. I found it at https://www.muhlenberg.edu/media/contentassets/pdf/campuslife/SDP\%2oReading\%2oLorde.pdf.

However, all the editions of Sister Outsider I have been able to locate omit this ending. So I am unable to determine at what stage the cut was made, or whether the decision was Lorde's or someone else's. I think I remember a stand-alone pamphlet version of the essay, with a stapled cardboard cover, being sold in feminist bookstores in the early 1980s; this may be that, but I can't find it, and must leave any further investigation for others.

35 And anyhow, I have international students from Africa and the Caribbean in my classes now. Maybe they do know who Césaire and Senghor were. And maybe if they don't, they need to. 
But can it be right to present this material in a way that denies our students and readers, Black and white, full knowledge of the sources from which the authors we revere drew some of their analysis, and some of their strength?

To return to Gilroy's point about the "two-way streets," and by way of filling in the historical record, I want to underline that Wright was present, active, and important at the founding moment of Les Temps Modernes, as well as helping to co-found the Paris-based Pan-Africanist Présence Africaine right around the same time. ${ }^{36}$ A translation of Wright's "Fire and Cloud" appeared in the very first issue of Les Temps Modernes in October 1945. It comes after Sartre's famous "présentation," where he called for the writer to be "engagé" and announced an "anthropologie synthétique," and right before Merleau-Ponty's important argument for intellectual responsibility, "La guerre a eu lieu" (The War Took Place). Wright's stories in this and later issues aren't relegated to the back of the book where we find the sociologically and politically valuable Documents that are meant to contribute to that "synthetic anthropology;" he's in the front section with the political and literary theorists. The 1946 special issue Les Temps Modernes devoted to the United States included another story of Wright's, and other texts he helped them select; they serialized Black Boy alongside with excerpts from Beauvoir's Pour une morale de l'ambiguité and Sartre's Qu'est ce que la littérature?, which both mention it. Wright was clearly

$36 \quad$ Doris Ruhe draws our attention to the close collaboration between the two journals: "Sartre's attention was drawn to African and Caribbean authors, if not earlier, thanks to his work on a 'committee of support' for the review Présence Africaine which Alioune Diop had just founded, a committee which also included such other intellectuals as Richard Wright, André Gide, Albert Camus, and Michel Leiris." [Lattention de Sartre fut attirée au plus tard sur les auteurs d'Afrique et des Caraïbes grâce à son travail dans un "comité de patronage" pour la revue Présence Africaine que venait de fonder Alioune Diop, comité auquel appartenaient également d'autres intellectuels tels que Richard Wright, André Gide, Albert Camus et Michel Leiris (Ruhe, "Femmes, juifs, noirs," 79-80).] The first issue of Présence Africaine (October-November 1947) included Alioune Diop, "Niam N'Goura, or Présence Africaine's raison d'être," translated by Richard Wright and Thomas Diop (19091). The French original appears in the same issue (7-14). So does Wright's "Bright and Morning Star," translated by Boris Vian, and Gwendolyn Brooks's poem "The Ballad of Pearl May Lee." Wright, working with the journal's editorial board until 1950, was also responsible for Présence Africaine's publishing Frank Marshall Davis, Samuel Allen, Horace Cayton, and C. L. R. James. Like La Revue du Monde Noir in the early 1930s, Présence Africaine also published an English edition. See Toro Kiuchi and Yoshinobu Hakutani, Richard Wright: A Documented Chronology, and Brent Hayes Edwards, "The Uses of Diaspora." 
someone the Temps Modernes group were thinking with, not just someone they were thinking about. ${ }^{37}$

From its first issue, Les Temps Modernes was the voice of an independent and anti-imperialist French left. ${ }^{38}$ As Sonia Kruks notes, its editors were early and consistent opponents of colonialism.

Anticolonial resistance had begun in Vietnam by 1945. As early as 1946, the journal Les Temps Modernes (for which Beauvoir was a member of the editorial board) took a firmly anticolonial position. Indeed, the journal adhered to a pro-independence position for all the French colonies well before most of the French left, including the highly influential Communist Party, did so. Most of the left urged a degree of reform in the French colonies, but until the late 1950s, saw actual independence as far fetched. ${ }^{39}$

Beauvoir's level of responsibility for Les Temps Modernes is often not marked as clearly as it should be.(Disappointingly, even the excellent New History of French Literature, which is organized through a series of significant events serving as windows on larger movements, covers the publication of the first issue of Les

37 My point here is to undo any impression that Beauvoir was simply appropriating or "sampling" Wright's work as a jumping-off point for her own analysis. For further details, see Simons, "Richard Wright"; Kiuchi and Hakutani, Richard Wright: A Documented Chronology; and Michel Fabre, "Interview with Simone de Beauvoir." Fabre describes Wright as in some ways closer to Beauvoir than to Sartre because Beauvoir, unlike Sartre, spoke English (Wright's French was never all that good) and because she was "more congenial and less impressive than Sartre and Camus .... Not that her thinking was less vigorous than theirs, but her manners were more open and her metaphysical interest always focused upon everyday implications and applications" (World of Richard Wright, 169). See Gines, "The Race/Gender Analogy," for Wright's influence on Sartre's play, La putain respectueuse, based on the case of the Scottsboro Boys.

38 Indeed, that honorable tradition continued for as long as the journal lasted: until Gallimard stopped publication at the end of 2018 , following the death of its last editor, Claude Lanzmann. (See Agnès Poirier, "Les Temps Modernes: Paris mourns the passing of the intellectual left's bible.")

39 Kruks, "Politics of Privilege," 200N21, referencing David Drake, Intellectuals and Politics in Postwar France. Elsewhere she notes that "[i]n the context of the intensifying cold war in the late 1940s, the journal took a position of 'critical support' for the Soviet Union, arguing that although a return to the prewar capitalist status quo was unacceptable, the Soviet Union could not be fully supported either" (Retrieving Experience: Subjectivity and Recognition in Feminist Politics, 30). See also Ian Birchall, Sartre Against Stalinism. But the details of Sartre's interactions with the Communist Party are of less interest to me here than the unwavering support the journal provided to the anti-colonial struggle, and to antiracist efforts in France. 
Temps Modernes as though Sartre had created the journal single-handedly. ${ }^{40}$ But as Doris Ruhe reminds us, the first issue, which appeared in October 1945, was "signed by Simone de Beauvoir, alongside Sartre and Merleau-Ponty, as official co-editor."41 Stève Bessac-Vaure has given a full (though oddly depoliticized) account of Beauvoir's role in sustaining the magazine's international character; letters to Algren make clear the level of her day to day attention to the often tedious tasks of maintaining its work, year after year, although this has seemed less interesting to her biographers than the details of her sex life and other emotional ups and downs. ${ }^{42}$ And in a way, the clearest evidence for Beauvoir's leftist and anti-colonialist work is the least newsworthy-what Auden called "the expending of powers / On the flat ephemeral pamphlet and the boring meeting"43 - the parts of La force des choses and Tout compte fait that even the most well-meaning of American readers tend to skip: acronyms of organizations that only lasted for a few years, numbers of people imprisoned or killed, lists of who signed or didn't sign the protest letter, explanations of why we quarreled with this person or that. ${ }^{44}$ This is the sort of work that Henri in Les mandarins would really like to put aside in order to work on his

40 Denis Hollier, ed., A New History of French Literature, 82. Most of the article concentrates on the later quarrel between Sartre and Camus. The only reference to Beauvoir in that article is a footnote to Les mandarins. To be fair, later entries in Hollier's history give Beauvoir her due: the publication of The Second Sex gets its own article, written by Toril Moi, who attributes the hostility with which that book was received by both left and right to the Cold War - "a deeply divided intellectual climate" — and the fact that "[i]n 1949 Beauvoir, like the rest of the group around Les Temps Modernes, belonged to the beleaguered non-aligned French left." The article on what came to be called the "new French feminisms," written by Jane Gallop, begins with the special issue of L'arc devoted (supposedly) to Beauvoir's work.

41 "En octobre 1945 avait paru le premier numéro ... pour lequel Simone de Beauvoir avec Sartre et Merleau-Ponty signe en tant que coéditrice responsable" (Ruhe, "Femmes, juifs, noirs, " 82).

42 Stève Bessac-Vaure, "Simone de Beauvoir as Mediator of Foreign Literature in Les Temps Modernes," 2015. According to Bessac-Vaure, Beauvoir's choices included Böll, Pavese, and Mayakovsky as well as Algren and Wright; he seems to be arguing that unlike Sartre, the fellow-traveler, Beauvoir's tastes were philosophical and literary rather than political, and notes that authors published by Les Temps Modernes diverged from the more restrictive list promulgated by the Communist party. What seems missing here is the whole conception of an independent left perspective. Both Communists and right-wing thinkers (on both sides of the Atlantic) sneered at that very conception, but we need not agree with them.

43 Auden, "Spain," in Selected Poems, 54.

44 Like L'Amérique au jour le jour 1947, those volumes of her autobiography were not written "for the ages" and we are not the audience to whom they are addressed. And yet historians of the post-war period, even those hostile to Beauvoir, still turn to them. 
novel. But he does not put it aside, and neither did Beauvoir, including in that novel. ${ }^{45}$

\section{$3 \quad$ Violence and Authenticity}

But if Richard Wright prepared Beauvoir to understand America, and America prepared her to understand women ... who or what prepared her to understand Richard Wright? What made it possible for Beauvoir to take a subject position by his side, or at least approach the world through his lens, given his explicit project in Native Son to make sympathy from whites, and especially from white women, impossible? He explains in a frequently-quoted passage from "How Bigger Was Born":

I had written a book of short stories which had been published under the title of Uncle Tom's Children. When the reviews of the book began to appear, I realized that I had made an awfully naïve mistake. I found that I had written a book which even bankers' daughters could read and weep over and feel good about. I swore to myself that if I ever wrote another book, no one would weep over it; that it would be so hard and deep that they would have to face it without the consolations of tears. It was this that made me get to work in dead earnest. ${ }^{46}$

I want to pair this with a quotation from an interview Beauvoir gave Michel Fabre, who asked how she first came across Native Son in 1940.

Sylvia Beach had told me: "You like violent books, well, here is a violent one, it will hit you hard." And I said, "Yes, I'll read it." I read it and I was very, very much impressed. ${ }^{47}$

45 See Les mandarins chapter 11, especially 2:440-49. When Les mandarins won the Goncourt prize, Beauvoir wrote that "Some young Malagasy sent me a wooden statue, appreciating that I had spoken of the repression of '47." [De jeunes Malgaches m'envoyèrent une statuette en bois, touchés que j'eusse parlé de la répression de 47" (FCh 2:57).]

46 Wright, "How Bigger Was Born," 874.

47 Michel Fabre, "Interview with Simone de Beauvoir," World of Richard Wright, 253. The interview took place on June 24, 1970. Sylvia Beach was the owner of "Shakespeare and Company," the famous English language bookstore in Paris, across the street from the Maison des amis des livres founded by her companion Adrienne Monnier. Beauvoir frequented both shops beginning in her student days: see $M J F R, 258,307,369$, and La force de l'âge (hereinafter $F A$ ), 57, 62. Beach is also well-known as the first publisher of James Joyce's Ulysses. 
And the fact is, Beauvoir did like violent books. One thing she and Sartre had in common with Richard Wright was a deep affinity for True Detective magazine and other gory real-life sources of faits divers. ${ }^{48}$ She is not an exception to the general existentialist tendency to associate violence with freedom: one might wonder why the acte gratuit, from Gide's Les caves du Vatican to Camus's L'étranger and Beauvoir's own L'invitée, and well beyond, is so frequently an act of murder. Somehow violence functions as a sign of authenticity: the eruption of violence into the everyday (or, the recognition that our notion of "the everyday" rests on a tacit acceptance of the violence it leaves unspoken) can put paid to a certain kind of bourgeois hypocrisy.

Beauvoir would recognize, in her self-criticism about the melodramatic conclusion of L'invitée, that there is a world of difference between killing someone off in a book and really killing them. ${ }^{49}$ But this doesn't mean that portraying Black men as killers in books can't have real-world dangerous effects down the line. The idea of racial "authenticity" has a troubled history, with which the other, existentialist meaning of "authenticity" is both productively and problematically intertwined. The question is, at what point does a search for raw authenticity in the experience of Others spill over into exoticism and/or radical chic: in today's terms, when does cultural appreciation become cultural appropriation?

Disentangling this is no simple matter. Consider something else that was going on in Beauvoir's Paris circle around the same time, the publication of a book called Jirai cracher sur vos tombes (I'll Spit on Your Graves). The book's real author was a young white Frenchman, Boris Vian, a trumpeter and passionate aficionado of jazz and all things American, and a key entrepreneur of the underground social scene in Saint-Germain-des-Prés that was becoming associated with tabloid versions of "existentialism." Vian was also a serious writer (he'd just been passed over for the Prix de la Pléiade for his quite good novel L'écume des jours, and was very angry about it), and he and his wife Michelle were quite close to Sartre, who invited him to contribute a column called "Chronique du menteur" (Liar's Chronicle) to Les Temps Modernes. In the case of Jirai cracher sur vos tombes, however, Vian claimed that he was only the

48 "Faits divers" refers to short news items or "human interest stories"; those Beauvoir mentions in La force de l'âge are often violent, including the crime of the Papin sisters on which Jean Genet would base his play, Les bonnes, and the story of Violette Nozières, on trial for killing her abusive father. See $F A$ 151-54.

"Novelists too often forget that in reality a gulf separates a dream of murder from a murder: to kill is not an everyday act." [Les romanciers oublient trop souvent que dans la réalité un abîme sépare un rêve de meurtre d'un meurtre; tuer n'est pas un acte quotidien (FA $386-87)$.] 
translator, and that the author of the novel (and its several sequels) was a lightskinned American Black man named Vernon Sullivan. The book itself is a sort of trashy thriller mystery. The hero and narrator, Lee Anderson, passes for white in order to seduce young white women ("bobby-soxers"). His plan is to avenge the lynching of his younger brother by deliberately "ruining" and then murdering a very rich man's daughter; he does so in a highly sadistic way, and then is himself lynched. (How he nonetheless manages to narrate the book is never explained.) So there is a double movement of passing here: Vian ventriloquizes a Black American whose hero pretends to be white in order to kill. However, Vian was exposed as the book's real author in 1947, because in real life a French man killed a woman, and when the police found the body, Vian's book was in the room, open to the page where Lee commits the murder. This led to a prosecution for obscenity, and Jirai cracher survos tombes was banned.

J'irai cracher sur vos tombes is, by any measure, a very bad book. However, in some ways it's not quite bad enough: it "works" both as a piece of pornography and as a crime novel, and the first-person narrative is skillful enough at placing us inside the main character's subjectivity that we are seduced into complicity with his crime. The sex scenes owe a lot to Henry Miller (who was prosecuted for obscenity at the same time as Vian) and the sexual violence, especially at the end, owes a lot to Bataille and to the surrealist tradition. Faulkner's Light in August is also a pretty evident influence. ${ }^{50}$

A successful fraud that crosses ethnic or gender lines is always interesting, because it reveals a cultural consensus about the plausible features of identity: the stunt "comes off" because of shared myths about gender and race. I'm offering Vian in part as an example of the Foucauldian point that at this time (and perhaps more generally), racist and anti-racist discourses were too close for comfort, so close as to be inextricable. Vian could claim to have exposed, or at least told some compelling stories about, the habitual casual violence and racism of Southern whites that motivates Anderson's revenge. ${ }^{51}$ But when the main character is lynched at the end, the reader (or anyhow this reader) feels that he deserves to die. So one is left wondering, wait a minute, what was the author trying to say? ${ }^{52}$ In the fake publicity surrounding the hoax, Vian claimed

5o This is even truer of Vian/Sullivan's second attempt, Les morts ont tous la même peau (The Dead All Have the Same Skin), whose desperately "passing" murderer turns out in the end to be white.

$5^{1}$ The rich white girl's family made their money in West Indies rum, much as in Native Son Mary Dalton's "progressive" father is a Chicago slumlord. Unlike Mary Dalton, however, the murder victim in Vian's novel is herself a blatant racist.

$5^{2}$ As literary critic Mounia Benalil explains: "The sadistic violence of the novel's closing scenes explosively unsettles the reading, while stripping bare the social diaspora and psy- 
that "Vernon Sullivan" could not step forward as the author because an actual Black man would have been lynched for writing such a book; and that claim was plausible. What then is the political effect of a white man's fantasy engagement with that real danger from a position of safety?

Vian's main motivation appears to have been simply to make a little money (and prove that he was capable of doing so). And yet, he seems to have held other political commitments that were somewhat sincere. (During the Algerian crisis he'd become famous again for writing and singing a breezy but devastating anti-war anthem, "Le déserteur": "M. le président, je vous fais une lettre....") Critics have noted how strongly J'irai cracher sur vos tombes draws on Wright's Native Son; Vian (with his wife's help) had already translated a short story of Wright's for Les Temps Modernes, and his translation of Wright's "Bright and Morning Star" also appeared in the first issue of Présence Africaine, in 1946. But J'irai cracher survos tombes is a pretty perverse reading of Native Son, where the murder is accidental and the white woman is not raped: if anything, it is Bigger's fear of being wrongfully accused of rape that leads to Mary Dalton's death. Boris Vian today remains something of a cult figure, as though his "problematic" texts are just light-hearted kitsch; other critics have taken him seriously as a premature post-modernist about race, language, and the impossibility of authenticity. Stephanie Brown makes a strong case for this; but to do so, she must sidestep political questions entirely. ${ }^{53}$ Perhaps the lapse of time makes this reasonable. One contemporary reader, Frantz Fanon, found himself in a quandary with rather higher stakes, when dealing with white negrophobia (and fetishism) in his clinical practice:

chic homelessness of 'mixed-blood' identity. No program of social or political reform for the Black condition is proposed. The lynching of Lee that ends the novel signifies a return to the white man's order, a return through which the racial status quo is maintained." [La violence sadique des scènes qui clôturent le roman "dérange" la lecture au même moment où elles représentent une mise à nu profonde de l'errance psychique et de la diaspora sociale de l'identité des "sang-mêlés." Aucun programme de réforme sociale ou politique de la condition des Noirs n'est proposé. Le lynchage de Lee en conclusion du roman traduit un retour à l'ordre de l'homme blanc, un retour par lequel le statu quo racial est maintenu ("Boris Vian face à l'institution littéraire: le cas de J'irai cracher sur vos tombes," 51).]

53 Stephanie Brown, "Black Comme Moi: Boris Vian and the African American Voice in Translation." Brown's reading is made plausible by Vian's many "knowing" metatextual asides, which seem to position the author as above the fray. For instance, the white woman, Lou, comments on the main character's voice: "I suppose you couldn't do anything about it,' she said. 'You were born like this.' 'No. I became like this.' [Je suppose que vous n'y pouviez rien, dit-elle. Vous êtes né comme ça.-Non. Je suis devenu comme ça (J'irai cracher, 136).] For a general account of Vian's career, see Philippe Boggio, Boris Vian. 
Another woman developed negrophobia after reading Jirai cracher sur vos tombes. We attempted to demonstrate the irrationality of her position in bringing her to see that the white victims were as morbid as the nègre. Moreover, we added, it was not a question of Blacks taking revenge as the title seemed to say, since the author was Boris Vian. We had to recognize that our efforts were in vain. This young woman would not understand. Anyone who has read the book will easily understand what ambivalence the phobia expresses. ${ }^{54}$

The whole episode reveals a dangerous slippage between a spectacular, sensationalized view and the voice of political commitment: both claim to be breaking silence as a challenge to the bourgeois social order, but this bare claim is not enough. Discourses speak through us, speak us, in ways that commonsense analysis (whether psychoanalytic or literary) can't disarm.

While Vian's view may be one plausible reading of Native Son and Black Boy, Beauvoir and Sartre (in La putain respectueuse) had a different reading. But it is not a simple matter to disentangle Beauvoir's relationship to some of the exoticizing discourses about race that she found in her social and intellectual circle in Paris. For instance, in La force de l'âge, she explains that before the war, during the avant-garde vogue for African art, she liked "les masques nègres" for the same reason she liked hermetic poems, surrealist films, abstract painting, old illuminations, and marionettes: they satisfied her taste for the supernatural, for a kind of stand-alone absolute, that persisted after she had given up her faith in God. ${ }^{55}$ She connects this also to what drew her to les faits divers in the

54 "Une autre femme avait la phobie du nègre depuis la lecture de Jirai cracher sur vos tombes. Nous avons essayé de lui montrer l'irrationalité de sa position en lui faisant remarquer que les victimes blanches étaient aussi morbides que le nègre. De plus avionsnous ajouté, il ne s'agit pas de revendications noires comme le laisserait entendre le titre, puisque Boris Vian en était l'auteur. Nous dûmes constater la vanité de nos efforts. Cette jeune femme ne voulait rien entendre. Quiconque a lu ce livre comprendra aisément quelle ambivalence exprime cette phobie" ( $P N M B$ 129-30; BSWM 123, translation altered).

55 "Sartre found it idle to deplore the gap between word and thing, between the given world and the created work of art; he saw this, on the contrary, as the underlying condition of literature and its reason for being; rather than dream of abolishing it, the writer should use it: his successes come from assuming this failure.

"Be that as it may, I had trouble getting used to this divorce; I wanted to write books without renouncing my 'trances'; I was torn. Because of this conflict I persisted for a long time in the conception of art I'd decided on before I met Sartre, which was rather different from his. I liked hermetic poems, surrealist films, abstract paintings, old engravings, antique tapestries, negro masks. I had an immoderate liking for puppet-shows; Podrecca's had displeased me on account of their realism, but I had seen some, including at [Dullin's] 
newspapers, and magazines like Détective: how violent and "extreme cases" disclosed the "unshakeable core of night" at the heart of every being, knocked down bourgeois façades, and led to a radical sense of freedom. ${ }^{56}$ It's also true that some of the lesbian eroticism of L'invitée takes place with an "exotic" background filling in for what Beauvoir's heroine cannot quite verbalize about her own desire: an important early scene unfolds as Françoise and Xavière watch Arab women dance in a café, and the younger woman has a passion for the famous "bal nègre," which the novel also labels the "bal colonial." Beauvoir describes that venue rather dispassionately in La force de l'âge; she says she liked to watch the "splendid animality" but that she didn't dance herself, and thought those whites who did looked ridiculous, "like hysterics having fits." 57 And she

Atelier, whose deliberate naïveté enchanted me. These predilections were partly explained by the influences of my youth. I had given up on God, but not on everything supernatural. Obviously I knew that a work created on earth could never speak any but an earthly language. But some seemed to me to have escaped from their author and taken back for themselves the meaning he'd wanted to give them; they stood up without anyone's help, mute and indecipherable, like great abandoned totems; these alone brought me in contact with something necessary and absolute."

[Sartre trouvait oiseux de déplorer cet écart entre le mot et la chose, entre l'œuvre créée et le monde donné: il y voyait au contraire la condition même de la littérature et sa raison d'être; l'écrivain doit en jouer, non rêver de l'abolir: ses réussites sont dans cet échec assumé.

Soit; je m'accommodais tout de même difficilement de ce divorce; je voulais faire des livres, mais non renoncer à mes “transes": j'étais tiraillée. C'est à cause de ce conflit que je persévérai longtemps dans la conception de l'art à laquelle je m’étais arrêtée avant de connaître Sartre, et qui s'éloignait de la sienne .... J'aimais les poèmes hermétiques, les films surréalistes, les tableaux abstraits, les vieilles enluminures, les tapisseries anciennes, les masques nègres. J'avais un goût immodéré pour les spectacles de marionnettes; celles de Podrecca m'avaient déplu par leur réalisme, mais j'en avais vu, entre autres à l'Atelier, dont la naïveté appuyée m'avait charmée. Ces prédilections s'expliquent en partie par les influences que j'avait subies dans ma jeunesse. J'avais renoncé au divin, non à toute espèce de surnaturel. Évidemment, je savais qu'une œuvre forgée sur terre ne peut jamais parler qu'une langue terrestre; mais certaines me semblaient avoir échappé à leur auteur et résorbé en elles le sens dont il avait voulu les charger; elles se tenaient debout, sans le secours de personne, muettes, indéchiffrables, pareilles à de grands totems abandonnés: en elles seules, je touchais quelque chose de nécessaire et d'absolu. $\left(F A 5^{0}-51\right)$.]

$56 \quad F A$ 150-51, 153. I discuss these passages further below.

57 "Sunday nights, we would leave behind the bitter elegance of skepticism and be excited by the splendid animality of the Blacks of the rue Blomet. I went many times with Olga to this ball, which Sonia and her friends also frequented. I ran into Marie Giraud, who had hardly changed since Berlin; she was hanging around Montparnasse and the places that the Montparnasse crowd favored. We were the exceptions: at that time few white women mixed with the Black crowd, fewer still ventured onto the dance floor: next to the agile Africans, the quivering Antillais, their stiffness was distressing to see; when they tried to shake it off, they started to look like hysterics having fits. I didn't go along with the snob- 
describes also being profoundly moved and attracted by American films featuring Black actors, such as Green Pastures and King Vidor's Hallelujah, and by Black American music, which (as she later realized) she didn't distinguish very clearly by genre.

Like most young people of our generation, we were deeply moved by negro spirituals, "work songs," and the "blues." The grab-bag of songs we loved included "Old Man River," "St James Infirmary," "Some of These Days," "The Man I Love," "Miss Hannah," "St Louis Blues," "Japansy," and "Blue Sky": men's mournful sorrows, wild joys, and broken hopes had found a voice that flew in the face of artistic "good manners," a voice that burst brutally from the heart of their night, racked by rebellion; born from vast collective emotions, those felt by each and by all, these songs touched us at a deep and personal place, one all humans share. ${ }^{58}$

bishness of the Café de Flore, I didn't imagine I was participating in Africa's grand erotic mystery; but I liked to watch the dancers; I drank punch; the noise, the smoke, the fumes of alcohol, the orchestra's violent rhythms put me in a daze; through the fog I saw beautiful happy faces drifting by. My heart beat a bit faster when the last dance broke into a tumult: as the festive bodies let loose, they seemed to bring me closer to my own ardor for life."

[Le dimanche soir, on délaissait les amères élégances du scepticisme, on s'exaltait sur la splendide animalité des Noirs de la rue Blomet. J'accompagnai plusieurs fois Olga à ce bal où venaient aussi Sonia et ses amies. J'y rencontrai Marie Giraud qui avait peu changé depuis Berlin: elle traînait à Montparnasse et dans les endroits que les gens de Montparnasse fréquentaient. Nous étions des exceptions: à cette époque, très peu de Blanches se mêlaient à la foule noire; moins encore se risquaient sur la piste: face aux souples Africains, aux Antillais frémissants, leur raideur était affligeante; si elles tentaient de s'en départir, elles se mettaient à ressembler à des hystériques en transe. Je ne donnais pas dans le snobisme des gens du Flore, je n'imaginais pas que je participais au grand mystère érotique de l'Afrique; mais j'aimais regarder les danseurs; je buvais du punch; le bruit, la fumée, les vapeurs d'alcool, les rythmes violents de l'orchestre m'engourdissaient; à travers cette brume je voyais passer de beaux visages heureux. Mon cœur battait un peu plus vite quand explosait le tumulte du quadrille final: dans le déchaînement des corps en fête, il me semblait toucher ma propre ardeur à vivre ( $F A 400)$.]

58 "Comme la plupart des jeunes gens de notre temps, nous étions passionnément émus par les 'negro spirituals,' par les 'chants de travail,' par les 'blues.' Nous aimions pêle-mêle Old Man River, St. James Infirmary, Some of these days, The man I love, Miss Hannah, St. Louis Blues, Japansy, Blue Sky; la plainte des hommes, leurs joies égarées, les espoirs brisés avaient trouvé pour se dire une voix qui défiait la politesse des arts réguliers, une voix brutalement jaillie du cœur de leur nuit et secouée de révolte; parce qu'ils étaient nés de vastes émotions collectives, celles de chacun, de tous - ces chants nous atteignaient chacun en ce point le plus intime de nous-mêmes qui nous est commun à tous" (FA 161). 
All this comes together in an admiration for Faulkner: both for Sanctuary"sex, in Faulkner, literally turned the world to fire and blood"59 — and later for Light in August:

The events that throw Christmas into the hands of the lynch mob are both as heartbreaking as life and as ineluctable as death. In this South, stripped of its future, with no truth left except its legend, the most turbulent explosions are frozen in place ahead of time by fate. Faulkner found a way to let his story unfold in time while also abolishing time... for Christmas, [the present day] is only a break between two chains of events, one running back to the day of his birth, the other running down to his horrific end, both embodying the same curse: black blood in his veins. ${ }^{60}$

Even if we remember that Wright himself, and later Toni Morrison, would acknowledge the influence of Light in August and draw deeply and productively on Faulkner's image-repertory, none of this is especially reassuring.

However, to return to the question I started from-what prepared Beauvoir to understand Richard Wright?-I'd argue that two preexisting strands prepared the ground for Wright's influence. One was the deep-seated disgust for European colonialism I discussed in chapter 3 ; the other was a fascination with the "otherness" of both African and African American art and music, a fascination she shared with many of her Parisian contemporaries. For both these strands, she was indebted, strangely enough, to surrealism. ${ }^{61}$

\section{Surrealism's Paradoxical Legacy}

I say "strangely enough" for several reasons. For one thing, post-war stand-offs between existentialists and surrealists could get quite vicious. There were

59 "[L]e sexe, chez Faulkner, met littéralement le monde à feu et à sang" (FA 214).

6o "[L]'aventure qui jette Christmas aux mains des lyncheurs fut à la fois poignante comme la vie et aussi inéluctable que la mort. Dans ce Sud, dépouillé de son avenir, et qui n’a plus d'autre vérité que sa légende, les plus tumultueux déchaînements sont figés d'avance par la fatalité; Faulkner avait su donner une durée à son histoire tout en annulant le temps .... [P]our Christmas, il n'est que la coupure entre deux séries, l'une qui remonte vers la jour de sa naissance, l'autre qui descend vers l'heure de son horrible fin, toutes deux manifestant une même malédiction: du sang noir dans les veines" ( $F A$ 271-72).

61 In what follows, I am construing "surrealism" broadly to include those who became dissidents or even constructed important works in opposition to the charismatic despotism of Breton. 
genuine philosophical points of non-coincidence between the groups, ${ }^{62}$ but political maneuverings played a larger part. The battle lines were drawn by Sartre's attack on surrealism in his polemic for engagement (the essays in Les Temps Modernes that became Qu'est-ce que la littérature?), the surrealists counterattacked in Rupture intégrale (1947), and the argument went on for decades; both groups were dancing the masochism tango with the French communist party, seeking ways to be politically effective while remaining independent, but they only rarely found themselves dancing in the same direction at the same time. ${ }^{63}$

Another reasons the pairing seems strange is that, while surrealism stridently presented itself as a revolutionary movement, it often does not look that way to us now, because its formal strategies have been so fully recuperated by consumer culture that what was once shocking is now cliché. Their particular claim of sexual non-conformism has a grain of truth, but only a grain. As Amy Lyford sees it, "the surrealist agenda for social transformation failed," because

[t]he myriad surrealist works that dramatize femininity as "other," deviant, deformed or violated are legendary for consistently promoting a power differential between men and women and for drawing on gender stereotypes.... Viewed at a distance, surrealist images of the 1920 s and 1930s seem to have laid the groundwork for an increasingly sexualized rhetoric of the mass media while opening up new terrain for social and sexual regulation. ${ }^{64}$

Lyford's discussion of the surrealists' supposedly liberatory "Recherches sur la sexualité" of 1928 shows that the sexual non-conformism they embraced

62 See Bruce Baugh, French Hegel: From Surrealism to Postmodernism.

63 See Susan Suleiman, "Le mythe de la femme et les écrivains: Breton ou la poésie." Suleiman points out (236) that Breton nonetheless was briefly a member, along with Beauvoir and Sartre, of the Rassemblement démocratique révolutionnaire, Sartre's post-war attempt to create a non-Communist "third way" on the left, and that all three would later sign the same protest letters against the Prague trials and the Manifeste des 121 against the French war on Algeria.

64 Amy Lyford, Surrealist Masculinities: Gender Anxiety and the Aesthetics of Post-World War I Reconstruction in France, 186. She continues: "Aragon's words (in '1930') presage T. J. Clark's 'bad dream of modernism,' a nightmare in which avant-garde explorations of new forms of consciousness simply make it easier for cultural institutions to colonize the spaces the avant-garde had cleared for the road to a liberated future" (186). 
was relentlessly heterosexual, and for the most part "dismissed women's experiences." ${ }^{\prime 6}$

The now-familiar feminist critique of surrealism began, in fact, with Simone de Beauvoir. The Second Sex is highly critical of surrealist myths. After discussing women's position as "Other" in three otherwise very different writers, Montherlant, D. H. Lawrence, and Claudel, Beauvoir skewers André Breton by quoting extensively from texts which swear undying total Amour for a series of different women; his supposedly "idealizing" (and supposedly avant-garde) view, she says, just amounts to one more objectification.

Despite the gulf that separates Claudel's religious world from Breton's poetic universe, there is an analogy in the role they assign to woman: she is an element of perturbation... ${ }^{66}$

This unique woman, both flesh and artifice, natural and human, has the same magic spell as the ambiguous objects the surrealists love: she is like the spoonshoe, the wolftable, the marble sugar-cube which the poet finds at the flea market or invents in a dream; she participates in the secret of familiar objects suddenly unveiled, the secret of plants and stones. ${ }^{67}$

Since Breton's perspective is exclusively poetic, it is exclusively as poetry, thus as other, that he contemplates woman.... She is poetry itself, in the here and now, that is to say for the man; whether she is also this for herself, we are not told. Breton does not speak of woman insofar as she is Subject .... Truth, Beauty, Poetry, she is Everything .... Everything, except herself. ${ }^{68}$

65 " $[\mathrm{F}]$ or all their efforts to promote new ideas about sexuality and sexual practice, the participants stuck to rather traditional ideas about sex and sexual difference. Some anxiety about the stability of male sexuality also permeated the discussions" (ibid., 144-45).

66 "Malgré l'abîme qui sépare le monde religieux de Claudel de l'univers poétique de Breton, il y a une analogie dans le rôle qu'ils assignent à la femme: elle est un élément de perturbation" ( $D S_{1: 366) \text {. }}$

67 "Cette femme unique, à la fois charnelle et artificielle, naturelle et humaine a le même sortilège que les objets équivoques aimés des surréalistes: elle est pareille à la cuillersoulier, à la table-loup, au sucre de marbre que le poète découvre à la foire aux puces ou invente en rêve; elle participe au secret des objets familiers soudain découverts dans leur vérité; et à celui des plantes et des pierres" ( $D S$ 1:370).

68 "La perspective de Breton étant exclusivement poétique c'est exclusivement comme poésie donc comme autre que la femme y est envisagée.... Elle est la poésie en soi, dans l'immédiat, c'est-à-dire pour l'homme; on ne nous dit pas si elle l'est aussi pour soi. Breton ne parle pas de la femme en tant qu'elle est sujet.... Vérité, Beauté, Poésie, elle est Tout.... Tout excepté soi-même" ( $D S$ 1:374-75). 
Much subsequent feminist writing on surrealism takes its cue from these observations. Xavière Gauthier followed Beauvoir's lead in one of the first works of second-wave feminist literary criticism in France, Surréalisme et sexualité ${ }^{69}$ which argues for the movement's intrinsic misogyny: "the surrealist woman is a male forgery."70 Beauvoir has often been a jumping-off point, too, for feminist writers who wish to complicate Gauthier's view by pointing to and re-valuing the many women painters, writers, and photographers who somehow did find surrealism artistically fruitful and productive, and still do. ${ }^{71}$ But some tight-rope walking is always necessary. There's stuff one can't un-see. As Mary Ann Caws memorably puts it:

Headless. And also footless. Often armless too; and always unarmed, except with poetry and passion. There they are, the surrealist women so shot and painted, so stressed and dismembered, punctured and severed: it is any wonder she has (we have) gone to pieces? ... Sure and strident, ready to do anything we can-except we can neither speak nor think nor

Susan Suleiman sees Beauvoir's takedown of Breton in The Second Sex as a "oui, mais": "[The method] consists of summing up the author's vision with a great deal of understanding, even a certain sympathy, only to ask one or two questions at the end which, like the serpent's tail where the poison is, attack where he is weakest.... The last sentences of the chapter are an execution: a gentle execution, but an undeniable one." [Cela consiste à résumer avec beaucoup de compréhension, voire avec une certaine sympathie la vision de l'auteur, pour poser à la fin une ou deux questions qui-semblables à la queue du scorpion où se trouve le poison-attaquent son point faible.... Ces dernières phrases du chapitre sont une exécution-exécution douce, mais indéniable ("Breton ou la poésie," 228-30).] Suleiman also reminds us that Montherlant, Claudel, and Breton were living authors (not subjects of academic study), underlining the polemical quality of Beauvoir's intervention.

69 Xavière Gauthier, Surréalisme et sexualité, 1971.

70 "La femme surréaliste est une forgerie de mâles" (Gauthier, 19o). Anna Watz ("Angela Carter and Xavière Gauthier's Surréalisme et sexualité") calls this "an assertion that might serve as a summary of her main argument" (101). Watz traces the further influence of Beauvoir, through Gautier, on Angela Carter's work, especially The Sadeian Woman, which itself had a strong influence on later feminist writers, especially in England. See Suleiman, "Breton ou la poésie," for a fuller discussion of the broader influence of this section of The Second Sex on feminist literary criticism.

71 See Katharine Conley, Automatic Woman: The Representation of Woman in Surrealism; Susan Suleiman, Subversive Intent: Gender, Politics, and the Avant-Garde; Mary Anne Caws, "Seeing the Surrealist Woman: We Are a Problem." In her commentary on Beauvoir's Breton chapter Suleiman goes farther, seeing all of second-wave feminist literary criticism, including her own work, as growing from this section of The Second Sex, in ways later writers usually failed at the time to acknowledge (Suleiman, "Breton ou la poésie"). 
see, nor walk and run, certainly not love and paint and write and be. Surrealist woman, problematic and imprisoned, for the other eyes. ${ }^{72}$

So it is strange to note how often in Beauvoir's memoirs she marks an affinity, especially in her youth, to the surrealist world view. She credits them with a transition, while still a (somewhat bored) philosophy student, not just in her literary tastes, but in the attitude to society these implied:

For the most part I came around to Brunschvicg's version of critical idealism, even though it left me unsatisfied on a number of points. On the boulevard Saint-Michel, Picart's bookshop welcomed students; there I'd leaf through the avant-garde reviews that were born and died like flies in those days. I read Breton, I read Aragon; surrealism won me over. After a while the literature of "inquiétude" struck me as insipid; I prefered the excesses of pure negation. Destruction of art, of morality, of language, systematic derangement of the senses, despair to the point of suicide: these excesses delighted me..$^{73}$

This enthusiasm dates back to her student days, when she was still liberating herself from the "proper young lady" persona of her Catholic upbringing. But it persisted, as when she mentioned surrealist films in the same breath with "les poémes hermétiques" and "les masques nègres" as continuing to satisfy her taste for the supernatural and the absolute in art, in a passage I referred to above. ${ }^{74}$ Later, in explaining why she was loath to analyze and interpret the behavior of those around her (and not especially good at it), she'll say that "surrealism had marked [her]" with a lasting attraction to what is mysterious and

72 Caws, "Seeing the Surrealist Woman," 11.

73 "En gros je me ralliai à l'idéalisme critique, tel que nous l'exposait Brunschvicg, bien que, sur bien des points, il me laissât sur ma faim. Je repris du goût pour la littérature. Sur le boulevard Saint-Michel, la librairie Picart s'ouvrait libéralement aux étudiants: j'y feuilletais les revues d'avant-garde qui en ce temps-là naissaient et mouraient comme des mouches: je lus Breton, Aragon; le surréalisme me conquit. L'inquiétude, à la longue, c'était fade; je préférai les outrances de la pure négation. Destruction de l'art, de la morale, du langage, dérèglement systématique, désespoir poussé jusqu'au suicide: ces excès me ravissaient" (Mémoires d'une jeune fille rangée, hereinafter $M J F R, 324-25)$. "Inquiétude" here refers to an earlier literature, to which she'd been introduced by her cousin Jacques, for instance Gide's Nourritures terrestres, which served as her bedside book for a time: writers who later seemed like rather timid bourgeois rebels, rather than revolutionaries. She would satirize them, and Jacques, relentlessly in Quand prime le spirituel. 
silent about human beings. ${ }^{75}$ She also acknowledges a more serious intellectual debt, crediting the surrealists with having helped her and Sartre admit (though incoherently) the existence of an unconscious:

Extreme cases fascinated us, for the same reason as neuroses and psychoses; the attitudes and passions of so-called normal people stood out in relief, purified and exaggerated. They also touched us in a different way. All perturbations satisfied our anarchism; we were charmed by the grotesque. One of our contradictions was that we denied the existence of the Unconscious; and yet Gide, the surrealists, and (despite our resistances) Freud himself, had convinced us that in every human being there lurks [what André Breton called] an unbreakable kernel of night [infracassable noyau de nuit], something that hides behind everyday social routine and cliché, but now and then bursts out with shock and scandal. Such explosions always reveal a truth, and those which gave rise to a freedom seemed especially stunning. We set particular store by all upheavals that laid bare the defects and hypocrisy of the bourgeoisie, knocking down the façades behind which the homes and hearts were hiding.... We were pleased to confirm that our own society was no more enlightened than those it labels "primitive." 76

In La force de l'âge, we accompany Beauvoir and Sartre to an early showing of Un chien andalou; we see them agreeing with and absorbing Antonin Artaud's praise of the "non-sens" of the Marx brothers; we go along to the surrealist exhibition of January 1938, with works by Duchamp and others; she describes in particular Salvador Dali's startling installation, a life-size taxicab with a

FA 146. "Le surréalisme m’avait marquée."

76 "Les cas extrêmes nous attachaient, au même titre que les névroses et les psychoses; on y retrouvait exagérées, épurées, dorées d'un saisissant relief les attitudes et les passions des gens qu'on appelle normaux. Ils nous touchaient encore d'une autre manière. Toute perturbation satisfaisait notre anarchisme; la monstruosité nous séduisait. Une de nos contradictions, c'est que nous niions l'inconscient; cependant Gide, les surréalistes, et, malgré nos résistances, Freud lui-même, nous avaient convaincus qu'il existait en tout être un 'infracassable noyau de nuit'; quelque chose qui ne réussit à percer ni les routines sociales ni les lieux communs du langage mais qui parfois éclate, scandaleusement. Dans ces explosions, toujours une vérité se révèle; et nous trouvions bouleversantes celles qui délivrent une liberté. Nous accordions un prix particulier à toutes les turbulences qui mettaient à nu les tares et les hypocrisies bourgeoises, abattant les façades derrière lesquelles se déguisent les foyers et les cœurs" (FA $\left.15^{-}-51\right)$. "Nous nous plaisions à constater que notre société n'était pas plus éclairée que celles qu'elle appelle 'primitives”' $\left(F A 1_{153}\right)$. 
mannequin inside, sitting in a heap of vegetables and snails. ${ }^{77}$ The show left its mark.

Amid an aroma of Brazilian coffee, objects emerged from carefully calculated shadows: a table-setting made of fur, a footstool whose supports were a women's legs; human hands came out of walls, doors, vases, everywhere. I don't think surrealism had a direct influence on us, but the air we breathed was heavy with it. It was the surrealists, for instance, who had started the fashion for the flea market, where I often spent my Sunday afternoons with Sartre and Olga. ${ }^{78}$

Never card-carrying members, they nonetheless swam in the same cultural waters and in the same direction. ${ }^{79}$ During and after the Second World War they would become close to several members of the original surrealist group, including the poet and ethnographer Michel Leiris, who had been a card-carrying member.

One attraction of the group we became part of was that almost all its members were former surrealists, who had broken with the movement at various times. For Sartre and me, our age, our University education, had kept us aside from the movement which indirectly had counted a great deal for us: we had inherited its contributions and its failures. When Limbour recounted the sessions of automatic writing, when Leiris and Queneau would hark back to the excommunications pronounced by Breton, his diktats and his rages, their accounts were more detailed, more

$77 \quad F A$ 60, 128-29, 370.

78 "Dans une odeur de café du Brésil, des objets émergeaient d'une obscurité soigneusement dosée: un couvert en fourrure, une table-tabouret soutenue par des jambes de femme; des portes, des murs, des vases, de partout s'échappaient des mains. Je ne crois pas que le surréalisme ait eu sur nous une influence directe; mais il avait imprégné l'air que nous respirions. C'était les surréalistes, par exemple, qui avaient mis à la mode la foire aux puces où souvent je passais avec Sartre ou Olga mes dimanches après-midi" (FA 370).

79 In L'invitée, as war threatens, dramatist Pierre Labrousse (who isn't Sartre exactly, but ... ) rejects the idea of fleeing France to live abroad: 'I was formed by a whole past,' continued Labrousse. 'The Ballets Russes, the theatre of the Vieux-Colombier, Picasso, surrealism, I'd be nothing without all that. Of course, I want the art of the future to be original, thanks to my work, but it will still be that tradition's future. One can't work in a vacuum, that leads nowhere." [“J'ai été formé par tout un passé, reprit Labrousse. Les Ballets russes, le VieuxColombier, Picasso, le surréalisme, je ne serais rien sans tout ça. Et bien sûr, je souhaite que l'art reçoive de moi un avenir original, mais qui soit l'avenir de cette tradition. On ne peut pas travailler dans le vide, ça ne mène à rien" (L'invitée 324).] 
alive, more true than any book, and they put us into possession of our prehistory. One day on the second floor of the Café de Flore, Sartre asked Queneau what had stayed with him from surrealism. "The impression of having once been young," he said. His response struck us, and we envied him. ${ }^{80}$

Leiris and his wife Zette became very close personal friends to Beauvoir and Sartre. ${ }^{81}$ As the Allies were closing in on Paris, when Camus advised them to go into hiding (one of his associates had named names under torture), they would take shelter briefly in the Leiris apartment, joining a list of Jews and résistants who hid out there during the Occupation. The two couples were clearly inseparable during the terrifying but exhilarating days that preceded the liberation of Paris. ${ }^{82}$ Leiris was a key member of the group that started Les Temps Modernes. ${ }^{83}$ Indeed (another strange thing) Beauvoir credits Leiris's autobiographical "essai-martyr," L'âge d'homme, with inspiring the project that became The Second Sex; ${ }^{84}$ she also credits her conversations with Zette, and some of the other wives of the post-surrealists, with awakening her to the existence of something she calls "la condition féminine," the situatedness of "relative creatures." 85

\section{$5 \quad$ Surrealism and Politics: More Two-Way Streets}

Now, some of what is strange about my claim that Beauvoir was politicized by surrealism rests on a strangeness or a fracture that is intrinsic to the surrealist

80 "Un des attraits de ce cercle dans lequel nous entrâmes, c'est que les membres en étaient presque tous d'anciens surréalistes dont la dissidence remontait à des temps plus ou moins lointains; notre âge, notre formation universitaire, nous avaient tenus, Sartre et moi, à l'écart de ce mouvement qui indirectement avait pourtant beaucoup compté pour nous; nous avions hérité de ses apports, de ses échecs; quand Limbour nous racontait des séances d'écriture automatique, quand Leiris et Queneau évoquaient les excommunications prononcées par Breton, ses diktats, ses colères, leurs récits, bien plus détaillés, plus vivants, plus vrais qu'aucun livre, nous mettaient en possession de notre préhistoire. Un jour, au premier étage du Flore, Sartre demanda à Queneau qu'est-ce qui lui restait du surréalisme: 'L'impression d'avoir eu une jeunesse,' nous dit-il. Sa réponse nous frappa, et nous l'enviâmes" ( $F A$ 654).

81 See $F A$ 640-41 for details of how the friendship and partnership began and developed.

$82 \quad F A$ 674. The account of "fiestas" or "fêtes" that closes La force de l'âge (and the related scene that opens Les mandarins) owes a great deal to Leiris's essay on the sacred in everyday life, as well as to the work of Roger Caillois and the Collège de Sociologie.

$83 \quad F A 643$.

$84 \quad$ FCh 1:135-36.

85 "[ÊE]tres relatifs" FA 654 . 
movement itself. This may have been one more instance of Beauvoir's "genius for the inappropriate," although it seems to have been widely shared. For starters, it is not obvious how a mystical aesthetic that involves a dérèglement of language, a refusal of visual representativity, an embrace of opacity, could really come together with committed politics, which we might tend to associate with a view of language as transparent and suited to communication. And yet somehow this did happen. The legacy of surrealism was also a strong legacy of anti-colonial political engagement, and of disengagement from nationalist and racist mystification. These moves took place in the real world (it was not simply as a matter of "subversive images"), and this was a two-way street: we can recognize the reciprocal influence between European surrealists and anti-colonialist artistic and militant movements in the French Caribbean and in Africa, resulting in enduring and mutually sustaining crosscultural alliances.

French surrealists are rightly credited with drawing attention to the value of African and African-American cultural productions, an attention that would be enormously productive for modernism in the visual arts. James Clifford, in The Predicament of Culture, also makes a strong case for the value of what he calls "ethnographic surrealism," with Leiris as his prime example. But the group has also been attacked as participating in what critics have called the "negrophilia" of the 1920s, vigorously defined by Petrine Archer-Straw in her book of that name; her examples range from the popular craze for Josephine Baker's banana dance to such serious works such as Picasso's "Les demoiselles d'Avignon." "Negrophilia" as she describes it involved almost a worship of Blackness, based on its supposed connection with the irrational, the "animal" nature of the body, the unconscious, and so forth. Archer-Straw notes that "the receptiveness of Europe's avant-garde toward this anti-aesthetic must be viewed against the background of their disillusionment with the social and political concerns of their own postwar culture"-in other words, this Blackness was really about whiteness. ${ }^{86}$

This is undeniably true: it is child's play to find examples of the sexually tinged "négritude blanche" that functioned as the very sign of the modern, at least as far back as Baudelaire's poems about Jeanne Duval. Surrealism from its very beginning, however, involved both a set of overexcited essentializing myths about Africa, the unconscious, the primitive, which we might reasonably find troubling, and a radical questioning of bourgeois French nationalism,

86 Petrine Archer-Straw, Negrophilia: Avant-Garde Paris and Black Culture in the 1920s, 87. See also Mariana Torgovnick, Gone Primitive: Savage Intellects, Modern Lives. For a different view, see Marjorie Perloff, "Tolerance and Taboo: Modern Primitivisms and Postmodernist Pieties." 
which saw clearly the links between conservative views about the family and conservative views about "civilizing mission" of the imperialist nation-state.

One familiar touchstone for this argument is the 1931 surrealist slogan, "Ne visitez pas l'Exposition Coloniale," which protested the European triumphalism that put actual African human beings on display with other "products." The surrealist counter-exposition, mounted in collaboration with the communists, displayed among other things "a group of statues on a table-one of a South Pacific girl wearing a grass skirt; another of a barefoot, Black child begging for money; and the third of the Virgin Mary holding the infant Jesuswith the heading "Fétiches Européens."”77 As Jonathan Eburne puts it, "Éluard and the surrealists argued that the immensely popular exposition, which paraded the 'success' of French colonial ventures in Africa, Vietnam and the West Indies, tacitly extended the legacy of 'villages pillaged and destroyed, crops burned, massacres from a hail of bullets, bombardments from the air, men working chained like beasts, women serving the amusements of commissioned louts."'88 The terms of this debate had been set earlier, as in this exchange in 1925 with Paul Claudel, who had said in an interview:

As for the present movements, not one can lead to a genuine renewal or creation. Neither Dadaism nor surrealism, which have only one meaning: homosexuality. Many are surprised that I am [not only] a good Catholic, but a writer, a diplomat, French ambassador, and a poet. But I find nothing strange about this. During the war, I went to South America to buy wheat, tinned meat, and lard for the army, and managed to save my country some two hundred million francs. ${ }^{89}$

The surrealists responded: "The only homosexual thing about our activity is the confusion it introduces into the minds of those who do not take part in it.... We take this opportunity to dissociate ourselves publicly from all that is French, in words and in actions." ${ }^{90}$ Visible in both conservative attack and

87 Linda M. Steer, "Photographic Appropriation: Ethnography and the Surrealist Other," 74.

88 Jonathan Eburne, Surrealism and the Art of Crime, 169.

89 Quoted in Helena Lewis, Dada Turns Red: The Politics of Surrealism, 26.

9o Maurice Nadeau, The History of Surrealism, 194. The reciprocal homophobia is also characteristic. A curious echo of this occurred in 1949, as Martine Reid mentions in her analysis of the responses to the publication of The Second Sex. François Mauriac had attacked the surrealists and existentialists together as harmful to the youth of France. The surrealists were not pleased to be put in the same sac. "Here, for instance, is the surrealist Jean Schuster: 'First, I challenge you to visit the surrealist continent and to look closely at its flora and fauna. Know that, just like any continent, it has its volcanos, whose eruptions 
radical riposte is the inextricable knotting-up of sexual and nationalist politics; Jonathan Eburne nicely describes this as "the ideological closed circuit of contemporary thought in the aftermath of the Great War, with its emphasis on continuity, patriotism, and domesticity." ${ }^{\text {"1 }} \mathrm{He}$ also notes "a steady stream of [surrealist] political tracts and pamphlets that sought to expose the forms of violence, both explicit and latent, exercised in the name of the state, the family, the middle-class, and even the values of Western humanism." One of these tracts, included in Nancy Cunard's 1934 Negro Anthology, was called "Murderous Humanitarianism"; drafted by René Crevel and signed also by Breton and others, it vigorously listed out the crimes of European colonialism, especially in Africa. ${ }^{92}$ While Sonia Kruks is right to point out that Les Temps Modernes was unusually early in articulating a consistent anti-colonial program, they had important surrealist precursors-one of whom, Michel Leiris, was on their editorial board.

Another familiar story is the surrealist disruption in 1925 of the Closerie des Lilas banquet to take a position against the Guerre du Rif (French suppression of an anti-colonialist revolt in Morocco), and also to confront the writer Rachilde, who had written a chauvinistic tract arguing that no patriotic French person could marry a German. Supposedly Philippe Soupault swung from the chandelier, sweeping the glasses and plates off the table, and Michel Leiris "almost got himself lynched," in Breton's rather infelicitous words, by shouting "Vive l'Allemagne" out the window. The confrontation with Rachilde in particular emphasizes what seems to me their most radical move: to trouble the

will not cease to surprise you. Second, we have never had anything to do with Mr. Sartre and Mr. Gide, and we refuse any supposedly dialectical comparison between their thinking and ours... Third, we have said over and over that there is nothing in common, except accidentally, between us and the nation (France), and that we are proud to constitute a permanent danger to her institutions.... Fourth, our aggressive withdrawal from your decaying society, our hostility toward its degrading ideas, find their corollary in our burning zeal to bring erotic hallucination to life." [Ainsi le surréaliste Jean Schuster, par exemple: " $1^{0}$ Je vous défie bien de faire le tour du continent surréaliste, et d'en observer de près la faune et la flore. Sachez que, comme tout continent, il possède des volcans dont les éruptions n'ont pas fini de vous surprendre. $2^{\circ}$ Nous n'avions jamais rien à voir avec MM. Sartre et Gide et nous nous refusons à toute confrontation prétendue dialectique entre leur esprit et le nôtre $\ldots 3^{\circ}$ Nous avons répété maintes fois qu'il n'y avait rien de commun qu'accidentel entre nous et la nation (la France), et que nous nous flattons de constituer un danger permanent pour ses institutions ... $4^{\circ}$ Notre retranchement agressif de votre société déliquescente, notre hostilité vis-à-vis de ses idéaux dégradants trouvent leur corollaire dans l'ardeur que nous mettons à oniriser érotiquement la vie" (Martine Reid, "Anatomie d'une réception: Le deuxième sexe," 211, emphasis added).]

91 Eburne, Surrealism and the Art of Crime, 21.

92 In Nancy Cunard, Negro Anthology, 574-75. 
whole idea of "Frenchness" that brought together both patriotism and what the American Claudels of today call "family values." Even their most obscure and experimental work could carry through this political stance: Leiris's Glossaire j'y serre mes gloses, a kind of "devil's dictionary" based on exploring puns and linguistic resonances within commonplace words, included "démocratie-la demi-crotte des assis ... famille — fameuse charmille d'infamie ... nationalpassionément anal ... patrie-tripaille ..."93

Seen in the context of then-ongoing debates, the surrealist affirmation of "Blackness," self-involved though it may have been, looks like part of a distinctly political and social program, directed against a particular set of mystifications, including patriotic and nationalist ones. But as Edward Hughes observes in his study of twentieth-century French exoticism, "the crucial question is the extent to which ... iconoclasm and gesturing toward the other ever becomes relationality." ${ }^{4}$ That question is never easy to answer. But rather than continuing to analyse it as a rhetorical stance, I want to note that the deployment of Blackness as a strategy of desublimation and dérèglement for Western intellectuals could and did lead to genuine commitments of solidarity with antiracist and postcolonial struggle.

I see the main indication that they are "genuine" in that they were embraced by a number of the poets and legislators of anti-colonialism - who were, surprisingly enough, quite often the same people. Perhaps the oddest example of this was how a visit from André Breton to Haiti triggered (sort of) a political rebellion there. Here is Breton's account, from a interview with Jean Duché included in the book Conversations.

Jean Duché: It seems you had a hand in the Haitian revolution. Could you comment on exactly what happened?

André Breton: Let's not exaggerate. At the end of 1945, the poverty, and consequently the patience, of the Haitian people had reached a breaking point. You have to realize that, on the huge Île de la Gonâve off the Haitian coast, men earned less than one American cent for an entire day's labor, and that, according to the most conservative newspapers, children in the suburbs of Port-au-Prince lived on tadpoles fished out of the sewers. This situation was made all the more poignant by the fact that the Haitian spirit, more than any other, miraculously continues to draw its

93 Democracy is half a turd, from comfortably well-off folks; the family is a famous tree-lined walk of shame; to be national is to be passionately anal; the fatherland is a heap of tripe ... it's much funnier than this, but the puns are untranslatable, sorry. 
vigor from the French Revolution; that the striking outline of Haitian history shows us man's most moving attempts to break away from slavery and into freedom.

In a first lecture on "Surrealism and Haiti," I tried, both for the sake of clarity and out of deference to the underlying spirit of this history, to align Surrealism's aims with the age-old goals of the Haitian peasantry. In conclusion, I felt driven to condemn "the imperialisms that the war's end has in no way averted and the cruelly maintained game of cat and mouse between stated ideals and eternal selfishness," as well as to reaffirm my allegiance to the motto on the Haitian flag: "Union makes strength." The newspaper $\mathrm{La}$ Ruche, the voice of the younger generation, which devoted the next day's issue to me, said that my words were electrifying and decided to take an insurrectional tone. Its confiscations and suspension immediately led to a student strike, followed within twenty-four hours by a general strike. Several days later, the government was held hostage. Unions were being started everywhere and free elections were promised. ${ }^{95}$

I am unsure how much credence to give this account, but I note that Breton's own view of his agency is rather modest - "let's not exaggerate" - and, more to the point, that the true causes he assigns behind the revolt are pragmatically materialist. (This is the same set of events I think Beauvoir is referring to when she says, in the introduction to The Second Sex, "the Blacks of Haiti have proved" that historically-based oppressions can be overturned.)

T. Denean Sharpley-Whiting calls our attention to early writing by Suzanne Césaire, who studied philosophy in Paris in the 1930s, and founded Tropiques with her husband and René Ménil—all three were teachers of Fanon. In a 1942 attack on some Martinican poets she found insipid and overly academic and Parnassian, she wrote, "Martinican poetry will be cannibal or it will not be," appropriating Breton's declaration that "beauty will be convulsive or it will not be." In another essay, she wrote: "Surrealism, with its emphasis on writing from the unconsciousness, gave us back some of our possibilities.... It's up to us to find the rest. By its guiding light."96 Fanon was right to ask why Breton, in his adulatory preface to Aimé Césaire's Cahier d'un retour au pays natal (Notebook

95 André Breton, Conversations, translated by Mark Polizotti. Quoted in "Breton and Haiti, Again," on Criticism \&c.

96 Quoted in T. Denean Sharpley-Whiting, "Tropiques and Suzanne Césaire: The Expanse of Negritude and Surrealism." For a more detailed discussion of this period, see Lori Cole, "Légitime défense: From Communism and Surrealism to Caribbean Self-Definition," and Robin Kelley, who writes in "A Poetics of Anti-Colonialism": "It is not too much to proclaim Suzanne Césaire as one of surrealism's most original theorists." 
of a Return to the Native Land), found it necessary to refer to Césaire as a great Black poet rather than simply a great poet. ${ }^{97}$ Yet it was not that Breton "appropriated" Césaire: Césaire had already "appropriated" surrealism, not in a "natural" way (as when Chester Himes described his "absurd" life as predating any acquaintance with "absurdist" literature), and not naïvely, but in the sense of James Clifford's story about "the first Thanksgiving": when the Pilgrim Fathers met Squanto, he had just returned from England. ${ }^{98}$ We would hardly want to describe the writers and artists of color who participated in these movements as dupes: surely it is better to speak of the relationship of the surrealist and negritude movements as dialectic and mutually nourishing, through a collaborative process and a reciprocal human gaze. ${ }^{99}$

What overall judgement can we come to, though, of the politics (and ethics) of the European surrealists? When Beauvoir took up this question directly in Pour une morale de l'ambiguité her answer was, it depends. After the consideration of the "serious man" I discussed above, she describes the radical disorder of the nihilist: her examples include Baudelaire, and Jouhandeau's "demoniacal man" who "stubbornly maintains the values of childhood, of a society, or of a Church in order to trample upon them." 100 The "démoniaque" is still pretty similar to the serious man, though; it is possible to go further, attempting "not

$97 \quad$ PNMB 31, BSWM 26.

98 James Clifford, The Predicament of Culture: Twentieth-Century Ethnography, Literature, and Art, 16. I am avoiding the terms "hybridity" and "contact zones": it is too easy to lose track of the dimension of power when speaking only of space and not of time.

99 Sam Bardaouil shows this dynamic at work in his book on the Egyptian surrealist group "Art and Liberty": a confluence of international networks and local political conditions in Cairo led in 1938 to the manifesto "Long Live Degenerate Art." Bardouil refers to the risk of situating this study within the exonerating didactic of post-colonial polemics [and of] reducing the case of Art and Liberty into another juxtaposition of socalled centers and peripheries, a binary which was not of concern to Art and Liberty ... Instead of picturing them as victims to a marginalizing Western-centrism, it is more adequate to highlight their role as active catalysts who contributed to the evolution and widening up of the formalistic qualities of surrealism at the time.

Bardouil, Surrealism in Egypt: Modernism and the Art and Liberty Group, 31-2. Perhaps a similar dynamic informed the writing of the tract, "Murderous Humanity," for Nancy Cunard's Negro Anthology, as the group that signed it included Martiniquans Pierre Yoyotte and J.M. Monnerot alongside Paul Éluard, Benjamin Peret, Yves Tanguy, Breton and Crevel. (The piece was translated into English by Samuel Beckett.)

100 Pour une morale de l'ambiguïté (hereinafter PMA ) 76-7; The Ethics of Ambiguity, translated by Bernard Frechtman (hereinafter $E A$ ), 52-3. “[L]'attitude du démonique, telle que l'a décrite Jouhandeau: on maintient avec entêtement les valeurs de l'enfance, celles d'une société ou d'une Église, afin de pouvoir les fouler aux pieds." 
just to trample but to annihilate" the world by ruining all projects, including one's own.

[Such] constant negation of the word by the word, of the act by the act, of art by art, took shape in the incoherence of Dadaism: by following strict instructions for disorder and anarchy, one would abolish all courses of conduct; all possible goals; oneself.

But this will to negate is self-refuting, for as soon as it appears it manifests as a presence.... If one is not resigned to suicide, one slides toward a more stable attitude than nihilism's tense refusal. Surrealism provides a historical and concrete example of the different possible developments. Certain initiates, such as Vaché and Crevel, chose the radical solution and killed themselves. Others destroyed their bodies and ruined their minds with drugs. Still others succeeded in committing a sort of moral suicide: by depopulating the surrounding world they found themselves in a desert, reduced to the level of the sub-human; they are no longer just trying to flee, they are fleeing. Then there are those who have gone back to seek the security of the serious man: they have returned to orderly life, choosing at random to take refuge in marriage, politics, or religion. Even those surrealists who have wanted to keep the faith could not help returning to the positive, the serious. Negation of aesthetic, spiritual, and moral values has become an ethics; unruliness [dérèglement] has become a rule. We have witnessed the establishment of a new Church, with dogmas, rites, priests, faithful flock and even martyrs; nothing today remains of Breton the wild destroyer: he's a pope. And since every assassination of painting is still a painted picture, many surrealists have found themselves authors of positive works; from the raw material of their rebellion they've built successful careers. Finally there are some who have been able to realize their freedom in an authentic return to the positive; without disavowing their freedom, they have given it substance. They have engaged themselves, without losing themselves, in political action, in intellectual or artistic research, in family or social life. ${ }^{101}$

101 "On peut aller beaucoup plus loin dans le refus, s'employant non à bafouer, mais à annihiler le monde refusé et soi-même avec lui .... La constante négation du mot par le mot, de l'acte par l'acte, de l'art par l'art, s'est trouvée réalisée par l'incohérence dadaïste; en appliquant une consigne de désordre et d'anarchie, on obtenait une abolition de toutes les conduites, donc de toutes les fins et de soi-même.

Mais cette volonté de négation se donne un perpétuel démenti, car dans le moment où elle se déploie elle se manifeste comme présence .... Si on ne se résigne pas au suicide, on glisse facilement vers une attitude plus stable que le refus crispé du nihilisme. Le 
The test of any aesthetic theory, then, was not what it claimed to do (ethically or politically), but what the claimants actually made of it, what they actually did do. Official surrealism may have betrayed its origins and become a religion (note that in mocking André Breton, she speaks almost like a movement insider); but an authentic development from surrealism was still possible. The point is that "surrealism," like Judaism, Frenchness, woman's situation, lesbianism, or anything else, can be lived in various ways, in bad faith or in freedom.

This view (though awfully abstract) has a certain explanatory power: we can account for the non-accidental importance of surrealism to Suzanne and Aimé Césaire, or Wifredo Lam, without extending our political blessing to such careerists of the Void as Salvador Dali (commercial, fascist, etc). ${ }^{102}$ When she turns to the more positive portrait of the surrealist who maintains his good faith, she is probably thinking of her new postwar friends, who included the poet and editor Raymond Queneau, and the sculptor Giacometti, whose emergence from the surrealist conception of an art independent of reality, and development of a different kind of experimental realism, she takes up later in her memoir and, transposed onto the character of Marcel, in Le sang des autres. ${ }^{103}$ But the best candidate for the "good" surrealist is Beauvoir's close friend and collaborator, Michel Leiris.

surréalisme nous fournit un exemple historique et concret de différentes évolutions possibles. Certains de ses adeptes, tel Vaché, Crevel, ont eu recours à la solution radicale du suicide; d'autres ont détruit leur corps et ruiné leur esprit par les drogues; d'autres ont réussi une sorte de suicide moral; à force de dépeupler le monde autour d'eux, ils se sont trouvés dans un désert, eux-mêmes descendus au niveau du sous-homme; ils n'essaient plus de fuir, ils fuient. Il y en a aussi qui ont recherché à nouveau la sécurité du sérieux; il se sont rangés, choisissant arbitrairement comme refuges le mariage, la politique, la religion. Ceux mêmes des surréalistes qui ont voulu demeurer fidèles à eux-mêmes n'ont pu éviter le retour au positif, au sérieux. La négation des valeurs esthétiques, spirituelles, morales, est devenue une éthique; le dérèglement, une règle; on a assisté à l'édification d'une nouvelle Église avec ses dogmes, ses rites, ses fidèles, ses prêtres et même ses martyrs; plus rien de destructeur aujourd'hui chez Breton: c'est un pape. Et comme tout assassinat de la peinture est encore un tableau, bien des surréalistes se sont trouvés les auteurs d'œuvres positives: leur révolte est devenue la matière sur laquelle s'est édifiée leur carrière. Enfin quelques-uns d'entre eux ont su, dans un authentique retour au positif, réaliser leur liberté; ils lui ont donné un contenu sans la renier; ils se sont engagés sans se perdre dans une action politique, dans des recherches intellectuelles ou artistiques, dans une vie familiale ou sociale" (PMA 77-9, EA 52-5, translation substantially altered).

102 James Clifford makes a very similar point when he says that "[s] urrealism coupled with ethnography recovers its early vocation as critical cultural politics, a vocation lost in later developments (Max Ernst devoting his energies to designing an oneiric double bed for Nelson and Happy Rockefeller, the general production of 'art' for the 'art world')" (Predicament of Culture, 147).

103 See $F A$ 558-59 and 620. 
Michel Leiris began his career as a surrealist poet, fascinated by language, dérèglement, women, and Africa, where he traveled as part of the infamous French Dakar-Djibouti "ethnographic" expedition of 1931-33. While that trip was billed as scientific, Leiris himself described it as a search for his own unconscious, as a "cure" for the neurosis that was (as he then saw it) modernity. The DakarDjibouti trip was not fieldwork as we now understand it, with participant/ observers ethically constrained to minimize disruption; rather it was a collecting trip on behalf of the French government, and the information was gathered more or less in the same way as the objects. Clifford: 'the mission's 'booty,' in Rivet and Rivière's term, included among its many photos, recordings, and documents 3,500 objects destined for the Trocadéro museum, soon to become the Musée de l'homme."104 In the course of the twenty-one months in Sudan and Ethiopia, Leiris became strongly disillusioned with the "mission" even as he helped to carry it out, and he revealed this on his return by publishing his diary of the journey, as L'Afrique fantôme. In a letter home, he wrote:

the methods by which we collect the objects, nine times out of ten, involve forced purchase, not to say requisition. All this casts something of a shadow over my life.... Indeed, I have the feeling that we are caught in a vicious circle: we loot from the Africans, with the pretext of teaching people to know and love them, which is to say, at the end of the day, to train other ethnographers who will go out and "love" them, and loot them, too. ${ }^{105}$

Another well-known quote from the diary itself:

August 29. While Lutten visits the village, I am working in the administrator's office with the interpreters. The objects arrive. Payment. The little black bag that contains the coins- the bag of tricks—is unknotted and reknotted over and over. The inventory notebook is filling up. It hasn't yet

104 Clifford, Predicament of Culture, 56.

105 "Les méthodes de collecte des objets sont, neuf fois sur dix, des méthodes d'achat forcé, pour ne pas dire de réquisition. Tout cela jette une certaine ombre sur ma vie ... [J]'ai bien l'impression qu'on tourne dans un cercle vicieux: on pille des Nègres, sous prétexte d'apprendre aux gens à les connaître et à les aimer, c'est-à-dire, en fin de compte, à former d'autres ethnographes qui iront eux aussi les 'aimer' et les piller" (Leiris, Miroir de l'Afrique, 204). See also Katharine Conley, "What Makes a Collection Surrealist? Twentieth-Century Cabinets of Curiosities in Paris and Houston." 
happened that we purchase all of a man's or woman's clothing and leave them naked in the road, but that will certainly come. ${ }^{106}$

Neither the uneasiness expressed here, nor the fact that he published L'Afrique fantôme over the objections of the mission's organizers, kept him from a successful career as an ethnographer and, ultimately, the director of the Musée de l'homme. He is remembered today mainly for his heterodox multi-volume autobiography, but also as a crusader against colonialism, whose work Fanon cites approvingly in several places. ${ }^{107}$

Looking at Leiris's trajectory can help us contextualize and understand the transformation in Beauvoir's own ideas about Blackness. The passages in her autobiography about negro spirituals, African masks, jazz and les faits divers have an exact analogue in Leiris's enthusiastic essays which appeared between 1929 and 1930 in the dissident surrealist magazine Documents, describing his enthusiasm for Vidor's Hallelujah and Lew Leslie's Black Birds Revue, which visited the Moulin Rouge. It is hard not to flinch when reading, for instance, in "Civilisation":

Spectacles like the Black Birds take us far deeper than art, to a point of human development where that bastard conception had not yet become overdeveloped.... We suffer from terrible regret, regret that we are so rigidly incapable of such simple and beautiful expression, regret that we are mediocre people living mediocre lives, so flat and ugly compared to these touching creatures who live like trees.... Thus this music and dance, far from lingering on our skin, plunge into us deep, organic roots which penetrate with a thousand branchings, a painful surgery transfusing a stronger blood. 108

106 “29 août. Pendant que Lutten visite le village, je travaille dans le bureau de l'administrateur avec les interprètes. Les objets arrivent, paiement. Le petit sac noir qui contient la monnaie—le sac à malice—est plusieurs fois dénoué et renoué. Le carnet d'inventaire s'emplit. Il ne nous est pas encore arrivé d'acheter à un homme ou une femme tous ses vêtements et de le laisser nu sur la route, mais cela viendra certainement" (Miroir de l'Afrique, 184-85).

107 See $P N M B$ 22, 31-2; BSWM 16, 26-7. The article Fanon uses is Leiris, "MartiniqueGuadeloupe-Haiti."

108 "Des spectacles tels que la revue des Black Birds nous ramènent très en deçà de l'art, à un point du développement humain où n'est pas encore hypertrophiée cette conception bâtarde .... [N]ous souffrons d'un terrible regret, regret d'être si durement incapables d'une expression aussi simple et aussi belle, regret d'être médiocres, vivant d'une vie médiocre, si plats et si laids devant ces créatures émouvantes comme des arbres.... C'est ainsi que ces musiques et ces danses, loin de s'attarder à notre peau, plongent en nous des 
Later, in L'âge d'homme, he would speak retrospectively of having found in jazz an "abandon to animal joy," the "myth of Edens of color."109 Timothy Bewes forthrightly calls this "fetishization of the exotic," which he compares to Conrad's Heart of Darkness, a "reverse racism."110 Indeed, Leiris himself came to describe his young view that pre-modern cultures were superior to the "green scum" of civilisation as "a kind of inverted racism."111

The question is how the writer of those naïvely admiring lines became, in the words of James Clifford, "perhaps the first professional ethnographer to name and analyse colonialism, in 1950, as an inescapable ideological ground," the man whose final understanding of the relationship of the metropole to the "dark continent" was "Africa does not need me."112 Perhaps ethnography could only be decolonized by those who started with a deep suspicion of civilization and its normativities. Somehow Leiris's trip to Africa and the daily writing he did there, helped him move from a fascination with the racialized Other as a (usefully distorting) mirror of the self, through unease about the relationships of commerce and exploitation this inevitably creates, toward actual relationships of collaboration, reciprocity, and responsibility. The improvisatory autobiographical project that followed - L'âge d'homme and the four volumes of $L a$ règle du jeu —-made it possible to dramatize his own "désarroi," and that of his national culture, rather than seeking to cure it by quasimagical means.

The clearest statement of this progress is the essay "L'ethnographe devant le colonialisme," which was first published in $195^{\circ}$ in Les Temps Modernes. According to the chronology in the Pléiade edition, this was first delivered as a talk with both Aimé Césaire and Claude Lévi-Strauss in the audience: he was literally facing both of them. And "colonialism" in 1950 was not the abstraction or metaphor it sometimes becomes in literary and cultural studies today. It is clearly understood here as an economic system, accompanied by its enabling mystifications to be sure, but distinguishable from them: the issue is not

racines profondes et organiques, qui nous pénètrent de leurs mille ramifications, chirurgie douloureuse mais nous communiquant un sang plus fort" (Documents 4, reprinted in Brisées, 31-7). See also Dawn Ades and Simon Baker, Undercover Surrealism: Georges Bataille and Documents.

109 "[A]bandon à la joie animale," "mythe des édens de couleur" (Leiris, L'âge d'homme, 189-90).

110 Timothy Bewes, "From the Shameful Order of Virility: Autobiography After Colonialism." (Bewes references Chinua Achebe's famous essay on Conrad.)

111 Sally Price and Jean Jamin, "Conversation with Michel Leiris," 162. See also "Jazz: An Interview with Michael Haggerty," 102, and Sally Price, "Michel Leiris, French Anthropology, and a Side Trip to the Antilles."

112 "[L]'Afrique n'a pas besoin de moi" (Miroir de l'Afrique, 89). Quoted in Clifford, Predicament of Culture, 173 . 
cultural "difference," but brutal economic exploitation, the extraction of resources.

Leiris begins by noting that ethnography developed alongside the spread of colonialism, still (in 1950) functions under its protective aegis, and is inextricably intertwined with it, whether or not the ethnographer wants that to be the case: "like it or not, they are part of the game."113 The ethnographer's subjects of study perceive him as part of the colonial administration, and they are not wrong to do so, since he cannot operate without that administration's support. Also, his investigations change the culture he is studying. All this gives the ethnographer an inescapable obligation toward the people he studies: he cannot close his eyes or wash his hands. Indeed, properly accurate research requires that he take into account the "perturbations" introduced by colonialism, and study societies in their real and current state, rather than referring back to some imagined idea of cultural "integrity" -imaginary, because even before colonialism no group lived in complete isolation.

Leiris deplores the "vaguely humanitarian veil" under which colonialism spread - pointing out that the Nazis made very similar claims. ${ }^{114}$ And yet humanism is central to his argument.

In spite of differences of color and culture, when we do ethnographic research we are always observing our fellow-creatures and we cannot adopt toward them the same indifference of, say, an entomologist casting a curious eye on insects fighting or devouring one another. ${ }^{115}$

Beyond the obligation of every citizen and every intellectual to speak out against injustices committed in his name, the ethnographer has a particular responsibility to serve as the advocate of the colonized vis-à-vis the metropole. But in working to safeguard the cultures they study, ethnographers should be careful not to confuse this with preserving them in some sort of intact state in order to continue to study them: culture is inseparable from history, not a static but a moving thing. ${ }^{116}$ The existentialist language, the echo of Hegel, should be familiar to my reader by now:

\footnotetext{
113 "[I]l est, bon gré mal gré, intégré à ce jeu" ("L'ethnographe devant le colonialisme," 85).

114 "[V]oile vaguement humanitaire" (ibid., 83). Note the echo of the surrealist manifesto, "Murderous Humanitarianism."

115 "En dépit des différences de couleur et de culture, quand nous faisons une enquête ethnographique ce sont toujours nos semblables que nous observons et nous ne pouvons adopter à leur égard l'indifférence, par exemple, de l'entomologiste qui regarde d'un œil curieux des insectes en train de se battre ou de s'entredévorer" (ibid., 85).

116 "[C]ette culture n'est pas une chose figée mais une chose mouvante" (ibid., 91).
} 
Once all of culture appears to us as a perpetual becoming, as the object of continual dépassements through which the underlying human group makes itself new, a desire to preserve the cultural particularisms of a colonized society no longer means anything. Or rather, such a desire means, practically, opposing oneself to that culture's very life. ${ }^{117}$

Attempts to preserve "traditional" cultures through a system of "reservations" are especially unacceptable: "There is something shocking about putting a society under a bell jar, treating human beings like animals penned in a zoo or isolated for a lab experiment,"118 and the idea that the people would be "happier" in that situation is a ruse: "We are only too eager to describe as 'happy' a people who make us happy when we look at them, because the spectacle gives us a poetic or aesthetic feeling."119 (This is the same distinction we saw, in both Beauvoir and Wright, between "happy" and "free.")

What is at stake here, in part, is the meaning of the term "culture": Leiris is opposed to the idea of culture as frozen into folklore for tourists (or scholars). And, as Bewes explains, for Leiris "the most 'authentic' Africans ... may be those who are more rather than less 'adulterated' by contact with the Westthat is to say, those who are aware of their status as colonized people, and who become promoters of an emancipation articulated in universal terms, informed by a sense of solidarity defined 'less by race than by condition."'120 According to Leiris, it is especially with this group-the group we might call "subalterns" but who were then called "évolués" - that the ethnographer must stand in a (non-paternalistic) solidarity, including by encouraging the development of archives and indigenous ethnographers. And it is important for ethnographers in the metropole to be encouraged to study societies "in their entirety"-including studying the whites, and the relationships involved in colonialism itself, and seeing "rituals" and the like as embedded in social contexts and "everyday life." In short, Leiris in $195^{\circ}$ proposed a kind of solidarity

117 "Or, dès l'instant que toute culture apparaît comme en perpétuel devenir et faisant l'objet de dépassements constants à mesure que le groupe humain qui en est le support se renouvelle, la volonté de conserver les particularismes culturels d'une société colonisée n'a plus aucune espèce de signification. Ou plutôt une telle volonté signifie, pratiquement, que c'est à la vie même d'une culture qu'on cherche à s'opposer" (ibid., 92).

118 "[I]l y a quelque chose de choquant dans le fait de mettre une société sous cloche (car c'est traiter des hommes comme des animaux qu'on parque dans un zoo ou qu'on enferme en vase clos pour une expérience de laboratoire)" (ibid., 94).

119 “[L]'on n'est que trop porté à regarder comme heureux un peuple qui nous rend, nous, heureux quand nous le regardons, en raison de l'émotion poétique ou esthétique que son spectacle nous donne" (ibid., 95).

Bewes, "From the Shameful Order of Virility," 464. 
that understood cultures as dynamic and developing, that recognized the situation of the colonized person as always mediated and mediating, and that left the destiny of indigenous peoples in their own hands. It is not so much a question of "working on," and more a question of "working with."

If we leave aside the Hegelian language of "dépassement" and "devenir," this essay may seem like a simple statement of what anthropologists now generally believe. At the time, however, it was directly opposed by none other than Pierre Bourdieu, who began his own fieldwork in Algeria as part of the occupying French army; ${ }^{121}$ and the work of Claude Lévi-Strauss was continuing in a rather different direction, away from the affirmation of human relationships and values, and toward a rather static, abstract conception of culture. ${ }^{122}$ Both Bourdieu and Lévi-Strauss are major figures to anthropology students today, unlike Leiris; for example, "L'ethnographe devant le colonialisme" has never been translated into English. And we might be less sanguine about "what anthropologists now generally believe" if we thought about the many anthropologists employed by the World Bank, and those embedded with armies in places like Iraq and Afghanistan.

But can we leave aside that existentialist language, that dynamic Hegelian sense of authenticity that speaks of "dépassement" and "devenir"? For anthropology in particular the sense of "progress" and improvement may feel embarassing, especially in the light of the many failures of decolonialization in Africa and elsewhere. (The hopeful tone of Leiris's comments about Mao now have a particular ring of unintended irony.) On the other hand, if one thinks of this from the point of view of a colonized subject, a dynamic sense of culture could well be an improvement over a static sense of structure, and wouldn't that be the viewpoint we should seek to adopt? Perhaps it is impossible to decide this question as a general matter. "L'ethnographe devant le colonialisme" is an existentialist ethics and, as Beauvoir said, an existentialist ethics has to be anchored in a concrete human situation. There are no recipes. ${ }^{123}$

121 See Derek Robbins, "The Responsibility of the Ethnographer: An Introduction to Pierre Bourdieu on 'Colonialism and Ethnography," 11-12, and Jane Goodman and Paul A. Silverstein, Bourdieu in Algeria: Colonial Politics, Ethnographic Practices, Theoretical Developments.

122 See Sally Price, "Michel Leiris, French Anthropology, and a Side Trip to the Antilles." See also Clifford, Predicament of Culture: "The great narrative of entropy and loss in Tristes tropiques expresses an inescapable, sad truth. But it is too neat, and it assumes a questionable Eurocentric position at the 'end' of a unified human history, gathering up, memorializing the world's local historicities" (14).

$123 P M A$ 194, EA 134. See chapter 3 above. 
While some Leiris scholars have seen his postwar transformation, and many of the ideas in this essay, as a result of Sartre's influence, I would argue as usual for more of a two-way street, less an appropriation or an influence than a collaboration and a dialogue. Long before Leiris met Sartre and Beauvoir, he was already an example of what they were working toward, or hoping for-an ethics of movement that would not degrade into the fixed content of the bourgeois serious man, a freedom that would move beyond theory (or fantasy) to find a purchase on, a genuine participation in and with, a demystified but meaningful world. Much of Leiris's mature literary work involves the reader in dizzing series of oscillations, digressions, and ironies which (unlike in Beauvoir's resolutely realist "metaphysical" novels) do not work toward or look for resolution. ${ }^{124}$ As Beauvoir put it in the long passage I quoted above, the idea was to "become engaged, without getting lost." ${ }^{125}$ How to do that, though? How to take yourself seriously without taking yourself too seriously, how to accept responsibility for your weight on the earth without turning into the "serious man" who clings to a set of unrevisable fixed ideas, with which he defends himself against all comers? ${ }^{126}$

\section{$7 \quad$ Beauvoir and Surrealism: L'invitée (Again)}

In my view, Beauvoir followed a similar path to her good friend Leiris in leaving voyeuristic "negrophilia" behind and moving toward a fully responsible

124 It is gratifying to see that Leiris's mature works are now getting the English translations they have so long deserved, by the wonderful Lydia Davis. Leiris mattered. It is rarely noted that one of Derrida's earliest forays into deconstruction, "Tympan," takes off from a long quoted passage from Leiris ... and even the short passages I quoted from Glossaire j'y serre mes gloses should suffice to indicate a broader indebtedness. Indeed, observing the contortions Derrida went through, at the end of his life, to articulate the kind of stable, committed ethical "position" he had done so much to render inarticulable, I might be tempted to ... a further digression, sorry.

125 PMA 79, EA 55.

126 In Nuits sans nuit et quelques jours sans jour [nights with no night and some days without sun], which Leiris published in 1961, he drew on notebooks and files to record in chronological order, with minimal comment, a series of dreams starting in the 1920s. Here in his nightmares is the real horror of the Occupation, and also of colonial life, along with more personal terrors. Here too he revisits, and revises, some of the troubling sexualized and racialized images I discussed earlier. He dreams in 1942 of a revue nègre like the Black Birds-which leads to boats full of corpses and rotting fish; in 1946, after the inauguration of an exhibit on Madagascar, he dreams that his "patron" Paul Rivet (the founding director of the Musée de l'homme) is directing a traveling circus or Buffalo Wild West traveling show in which he must perform ... Leiris, Nuits sans nuit, 140, 166. 
attention to colonial histories, an evolution that begins to be visible in the moral period, and solidifies with L'Amérique au jour le jour 1947 and The Second Sex. Such attention certainly animated Beauvoir's committed collaborative work with Les Temps Modernes, and her crucial and risky public anti-colonialist activism during the Algerian war and afterward. One thing we can learn, perhaps, from Leiris, is that the quest to isolate genuine or authentic "difference" is, not just an unattainable fantasy, but actively dangerous, and at odds with real possibilities for effective relationship and solidarity.

If I pose to Beauvoir (as it were) the question Sartre asked Queneau-what remained to you from surrealism - one answer might not be entirely dissimilar: there is an association with youth, with books that shocked her parents, with an iconoclastic anti-rationalism and a critique of the West and of civilization, that was particularly helpful as a corrective to the aridity of the idealist philosophy she was learning at the Sorbonne, and as a liberating "déclic" to shake off the influence of two writers, Barrès and Claudel, who looked radical, but were actually quite right-wing. (Both had been important to her in girlhood, along with Gide; Barrès, forgotten today, wrote a very influential and terribly anti-semitic book called Les déracinés. $)^{127}$ Surrealism itself, though, wouldn't be allowed to serve as any kind of alibi: in Quand prime le spirituel, it is the conman and masher Denis who pushes Marguerite to read the "Manifestos of Surrealism" and praises the idea of the acte gratuit as an explanation for his own bad faith and bad behavior. (There's more than a little of cousin Jacques in Denis as well.) It's important to keep in mind that the autobiographical works record a process of Bildung, of development and change - that same devenir and dépassement, in a way-and this is true not just for the first volume, but perhaps even more for La force de l'âge: an important theme is, how mistaken Beauvoir and Sartre both were, before the war, in not truly understanding the political stakes of their own privilege. Insofar as Beauvoir links her lingering taste for surrealist poems and African masks with a nostalgia for the absolute, she marks the process of leaving that behind: the pursuit of a totality, without limits, is not what a grown-up existentialist ought to do.

Perhaps the writing of L'invitée involved a similar process. She records an encounter during the Occupation, while she was writing it, with the avantgarde playwright Arthur Adamov (he was associated with the surrealists and with the Theatre of the Absurd).

I was working, just as I used to do, in a booth at the back [of the Café Dôme], but there were no more refugees reading the papers or playing 
chess; most of the foreigners had disappeared, and almost all the faces I knew. From time to time Adamov would loom up by my table, his eyes growing wider and wider, endlessly questioning everything.... "What are you writing?" he asked me once. I was brave enough to confess: "A novel." "A novel?" he repeated. "A real novel? With a beginning, a middle, an end?" He seemed as dumbfounded as my father's friends had been, long ago, by the poems of Max Jacob. ${ }^{128}$

Adamov might well have been surprised to see her writing "a real novel," that is to say, a traditional one, after the explosions of surrealism had (supposedly) demolished referentiality - not to mention, in the middle of a war. This is additionally surprising as we've seen Beauvoir's own tastes, at least as a reader, put her in sympathetic contact with the movement whose slogan was "destruction et poésie," and which had declared such novels dead and buried. But interestingly, when Linvitée was published, to general acclaim, Adamov did not dislike it.

I anticipated that Adamov would be scornful. "So," I said to him, "have you seen it? A real novel with a beginning, a middle, and an end, do you utterly despise it?" He shook his head and looked at me gravely: "I wouldn't go that far. There's Xavière," he said. "There is Xavière."129

Indeed, Xavière functions a bit like Breton's Nadja, or the unnamed woman in Philippe Soupault's Dernières nuits à Paris, as that "infracassable noyau de nuit," the silent, mysterious, possibly mad object whom the othercharacters passionately attempt and fail to "read," understand, possess. Pierre calls her a "perle noire," a black pearl:

128 "Je travaillais, comme autrefois, dans un des boxes du fond, mais il n'y avait plus de réfugiés occupés à lire les journaux ou à jouer aux échecs; la plupart des étrangers avaient disparu, et presque tous les visages que je connaissais. De temps en temps, Adamov surgissait devant ma table, les yeux de plus en plus écarquillés, dans une interrogation sans fin.... 'Mais qu'est-ce que vous écrivez?' me demande-t-il une fois. J'avouai courageusement: 'Un roman.-Un roman? répéta-t-il, un vrai roman? Avec un commencement, un milieu, une fin?' Il avait l'air aussi abasourdi que les amis de mon père, autrefois, devant les poèmes de Max Jacob" ( $F A$ 543).

Max Jacob, the friend of Picasso and Apollinaire, was a precursor of surrealism and a favorite of Beauvoir's cousin Jacques. See Mémoires d'une jeune fille rangée, hereinafter $M J F R, 279-80,312-13$.

129 "Je m'attendais au dédain d'Adamov. 'Alors, lui dis-je, vous avez vu? C'est un vrai roman avec un commencement, un milieu, une fin; ça vous déplaît bien fort?' Il hocha la tête, son regard s'alourdit: 'Pas tant que ça. Il y a Xavière, dit-il. Il y a Xavière'” (FA 637-38). 
"Everything about her is so pure, and so violent."

"Why black?" asked Françoise.

"Because there's a kind of perversity about her. It's as if she has a need, sometimes, to do harm, to do herself harm and make herself hated."130

Xavière is associated with "mysterious perturbations" and obscure, self-absorbed rituals: along with "perversité," the words "sorcière" and "sorcellerie," witch and witchcraft, accompany her throughout the novel. ${ }^{131}$ Where Françoise initially sees an "enfant capricieuse," a capricious child, Pierre sees "a fierce and exacting soul": "I find it moving, this inability of hers to form human relationships with people."132 Pierre treats Xavière as a "Pythie," a Pythian priestess or sybil, and a "living question mark." 133 Françoise comes to espouse his view to the point of being distressed that Pierre himself will destroy it: "This black pearl, this austere angel, with his caressing man's hands Pierre will turn her into a swooning woman ... [Françoise] looked on with a kind of horror."134

In their more rational moments, the adult tête-à-têtes for which Xavière jealously despises them, Pierre and Françoise debate whether Xavière's refusal or inability (but which is it?) to work or study, to make plans or keep appointments, to consider the feelings or needs of others, and her insistence that anything but living in the moment is "bourgeois," constitute a genuine alternative ethic ("morale"), a challenge to the rules for living Pierre and Françoise have carefully worked out for themselves - or whether it is simply "veulerie" (spinelessness). Pierre argues that "when inertia is taken to such an extreme point, one can't go on calling it spinelessness; it takes on a kind of power of its own."135 (At one point Pierre and Françoise, listening at her door, hear her making non-human moaning sounds, a "plainte animale," and are afraid to go in.) $)^{136}$ And insofar as Françoise finally does buy into this, Xavière's power becomes real. "This sorceress had made off with her image and subjected it to the worst

130 "Tout est si pur en elle et si violent.

-Pourquoi noire? dit Françoise.

-À cause de cette espèce de perversité qu'elle a. On dirait que c'est un besoin chez elle par moments de faire du mal, de se faire mal et de se faire haïr" (L'invitée, 164).

131 "[D]e mystérieuses perturbations" (L'invitée, 45). See also for instance L'invitée 164, 190, 226, 253 .

132 "[Â] $]$ me exigeante et farouche" (L'invitée, 164). "[Ç] a me touche, cette incapacité où elle est d'avoir des rapports humains avec les gens" (164).

133 "[U]ne Pythie" (L'invitée, 140); "un vivant point d'interrogation" (156).

134 "[C]ette perle noire, cet ange austère, avec ses mains caressantes d'homme, Pierre en ferait une femme pâmée; déjà il avait écrasé ses lèvres contre les lèvres douces ... Elle le regarda avec une espèce d'horreur" (L'invitée, 260).

135 "[Q]uand on pousse l'inertie jusqu'au point où elle la pousse, le nom de veulerie ne convient plus, ca prend une espèce de puissance" (L'invitée, 163).

136 L'invitée, 386. 
of spells, just as she pleased."137 (One way to understand Françoise's over-thetop murderous solution: if what she's up against is voodoo, sending Xavière back to Rouen won't make a bit of difference. Witches can fly.)

The uncanny connection between the heart of darkness that is Xavière and actual dark-skinned people from warm places is also explicit throughout L'invitée. Her irrational, alluring, but dangerous sensuality is especially on view in four bar scenes involving dancing, one set in the famous Bal Nègre, two in a "café maure" (moorish café) with belly-dancing, and one in a Spanish flamenco establishment, to which the trio is introduced by an accomplished actress and dancer, Paule Berger: it is there that Xavière appears most seriously disturbed, burning her own hand studiously with her cigarette, a gesture that Pierre finds "sacrée" and "expiatoire." 138 Three of the four scenes have the same structure Beauvoir described when evoking the Bal Nègre in her memoir: Xavière watches the dancers, absorbed, envious, wanting to become them, nearly succeeding (but not quite); Françoise enjoys herself but does not dance. She watches Xavière. In chapter 2, we are introduced both to the moorish café and to Xavière:

"I wish I knew how to dance like that," said Xavière; her shoulders shivered, a slight undulation ran over her body. Françoise smiled at her. She was sorry the day was coming to an end; Xavière had been charming.

"In Fez, in the red-light district, Labrousse and I saw some of them dancing naked," said Françoise, "but it was a bit too much like an anatomy lesson."

"What things you've seen!" said Xavière, with a touch of resentment... ${ }^{139}$

The dancer moved toward the middle of the floor; her haunches undulated, her belly rippled to the rhythm of the tambourine.

"It's as if a demon was trapped in her body and trying to escape," said Xavière. She leaned forward, fascinated. Françoise settled deeper into the

137 “[C]ette sorcière s'était emparé de son image et lui faisait subir à son gré les pires envoûtements" (L'invitée, 298).

138 See Toril Moi, "L'invitée: An Existentialist Melodrama." As I said in chapter 2, I am not in sympathy with the psychoanalytic "payoff" of Moi's reading, but her analysis of this scene is a powerful one.

139 "Assises au fond du café maure sur des coussins de laine rêche, Françoise et Xavière regardaient la danseuse arabe.

- Je voudrais savoir danser ainsi, dit Xavière; ses épaules frémirent, une ondulation légère parcourut son corps. Françoise lui sourit, elle regrettait que la journée s'achevât; Xavière avait été charmante.

-À Fez, dans le quartier réservé, nous en avons vu, Labrousse et moi, qui dansaient nues, dit Françoise, mais ça ressemblait un peu trop à une démonstration anatomique.

- Vous en avez vu des choses! dit Xavière avec une nuance de rancune" (L'invitée, 21). 
cushions; she, too, was touched by all this cheap glitter, but what delighted her more than anything was that she'd brought Xavière's sad little existence into her own life. ${ }^{140}$

The scene in the Bal Nègre itself-labelled the "Bal colonial" by a sign on its door-uses some of the very same language as the autobiographical passage I quoted above.

In that wide room with its pale frescos, banal as a banqueting hall, nearly all one saw were faces of color; all shades of skin were there, from ebony black to rose-ochre. These Blacks danced with lewd abandon, but such pure rhythm was in their movements that even the rumba, crude and naïve as it was, retained the sacred character of primitive ritual. The whites who mixed with them did less well; the women in particular resembled stiff wind-up toys, or hysterics having fits. All except Xavière, whose perfect grace flew in the face of both decency and indecency. ${ }^{141}$

But Xavière, as usual, is not satisfied. "They have the devil under their skin, these négresses,"142 she said angrily. "I'll never be able to dance like that." Françoise disagrees. "You know, you dance very well [drôlement bien]."143

140 "La danseuse s'avança vers le milieu de la salle; ses hanches ondulaient, son ventre tressaillit au rythme du tambourin.

- On dirait un démon qui cherche à s'échapper de son corps, dit Xavière. Elle se pencha en avant, fascinée.... Françoise s'enfonça dans les coussins; elle aussi, elle était touchée par tout ce clinquant facile, mais ce qui l'enchantait surtout s'était d'avoir annexé à sa vie cette petite existence triste...." (L'invitée, 22-3).

141 "Dans cette grande pièce décorée de fresques pâles et qui ressemblait dans sa banalité à une salle de noces et banquets, on ne voyait guère que des visages de couleur: du noir d'ébène à l'ocre rosé, on trouvait là toutes les nuances de peau. Ces noirs dansaient avec une obscénité déchaînée, mais leurs mouvements avaient un rythme si pur que dans sa rudesse naïve cette rumba gardait le caractère sacré d'un rite primitif. Les blancs qui se mêlaient à eux avaient moins de bonheur; les femmes surtout ressemblaient à de raides mécaniques ou à des hystériques en transes. Il n'y avait que Xavière dont la grâce parfaite défiât à la fois l'obscénité et la décence" (L'invitée, 310).

142 As in my discussion of L'Amérique au jour le jour 1947 above, I have decided to leave the words négresse and nègre in French because there is no way to get this right. Today's dictionary leaves no doubt that the terms are "injurieux," insulting, in the same way that "Negro" would be in today's United States. But language changes; it is less clear whether either of these terms would have been insulting in the 1940s; probably it depended on context; any choice on my part would be tendentious.

143 'D'un signe de tête, Xavière déclina une nouvelle invitation et elle revint s'asseoir à côté de Françoise.

—Elles ont un diable dans la peau, ces négresses, dit-elle avec colère. Jamais je n'arriverai à danser comme ça. 
Now, if we were in American literature, or some Vian-like imitation thereof, Xavière's uncanny dancing ability and the way she is drawn to the dance floor might foreshadow a revelation that she had some "Black blood," was, in short, a tragic mulatto, like Faulkner's Joe Christmas. But that's not where this is going.

"You dance really well, you know," said Françoise.

"Yes, not too bad for a civilized person,"144 said Xavière in a disdainful tone. She was staring at something in the middle of the dance floor. "She's dancing with that little Creole again," she said, pointing to Lise Malan with her eyes. "She hasn't let go of him since we got here. He's shamefully pretty."

It's true he was charming, slim as could be in his tight brown jacket. An even more plaintive moan slipped from Xavière's lips:

"Ah! she said, I would give a year of my life to be that négresse for one hour.... Or else, one would have to be rich enough to buy her and lock her up," said Xavière. “Isn't it Baudelaire who did that? Imagine, when you go home, instead of a dog or a cat, to find this sumptuous creature purring beside a wood fire?"145

Actually, Baudelaire did not do this: for the record, the Haitian-born dancer Jeanne Duval was his mistress, his "Vénus noire," and his "muse" (as Wikipedia puts it); but he never literally "owned" or confined her. He had hardly any more

Elle trempa ses lèvres dans son verre.

—Que c'est sucré! Je ne peux pas le boire, dit-elle.

-Vous dansez drôlement bien, vous savez, dit Françoise" (L'invitée, 311 ).

144 See also the following exchange: "In the end you'll dance just as well as the négresse does.' 'Alas, it's impossible,' said Xavière." [Vous finirez par danser aussi bien que la négresse.Hélas! ce n'est pas possible, dit Xavière (L'invitée, 315).]

145 “-Vous dansez drôlement bien, vous savez, dit Françoise.

-Oui, pour une civilisée, dit Xavière d'un ton méprisant. Elle regardait fixement quelque chose au milieu de la piste.

-Elle danse encore avec ce petit créole, dit-elle; ses yeux désignaient Lise Malan. Elle ne l'a pas lâché depuis que nous sommes arrivées. Elle ajouta d'un ton plaintif: il est honteusement joli.

C'est vrai qu'il était charmant, tout mince dans une veste cintrée couleur bois de rose. Des lèvres de Xavière s'échappa un gémissement plus plaintif encore:

-Ah! dit-elle, je donnerais un an de ma vie pour être pendant une heure cette négresse.... Ou alors, il faudrait être assez riche pour l'acheter et pour la séquestrer, dit Xavière. C'est Baudelaire qui avait fait ça, n'est-ce pas? Vous imaginez, quand on rentre chez soi, au lieu d'un chien ou d'un chat, trouver cette somptueuse créature en train de ronronner au coin du feu de bois!" (L'invitée, 311 ). 
money than she did, by the end. Objectified, yes; enslaved, no. ${ }^{146}$ One suspects Françoise knows the difference, but she is not in a pedagogical mood.

A Black naked body stretched out before a wood fire ... was this what Xavière dreamed of? How far did her dream go? ${ }^{147}$

Now, this whole novel is about looking, about the Look of the Other and its power to steal the world. (Pierre is amazed at Françoise's ability to experience a philosophical issue in such a visceral manner: but she does, and so, apparently, did her creator. $)^{148}$ For now, though, suppose we focus not on what happens when Xavière's ability to look back at Françoise contests Françoise's monopoly of the subject position, but what happens when that (Sartrean) either/ or power problematic intersects (so to speak) with something that is problematic for us: the well-sedimented tendency for white people to see people of color, particularly entertainers of color, as objects who exist purely for our viewing pleasure, like zoo animals. To answer Petrine Archer-Straw's question, what I need to decide is first whether Françoise shares, or merely envies, Xavière's problematic "gaze"; 149 and then, whether "Beauvoir," or at least the novel as a whole, shares in it, or merely describes it. There is, indisputably, "negrophilia" in this scene. Whose negrophilia is it?

146 Angela Carter, who retold their story from Jeanne's point of view in "Black Venus," summarized it in a 1985 interview: "He treated her, as they say, 'Quite well,' except that he appears not to have taken her in any degree seriously as a human being” (Kerryn Goldsworthy, "Angela Carter," 11).

147 “-Un corps noir et nu couché de tout son long devant un feu de bois ... était-ce cela que Xavière rêvait? Jusqu'où allait son rêve?" (L'invitée, 311, ellipsis in original).

148 See L'invitée, 376. Margaret Simons has drawn attention to a line from Beauvoir's student diary, where she is reflecting on the difference between herself and Merleau-Ponty, a fellow student: "those problems that he lives in his mind, I live them with my arms and my legs" (Beauvoir, Diary of a Philosophy Student, 2). Any reading of Beauvoir's letters and autobiography certainly bears out this claim.

149 The issue of "sexual tourism" with respect to the Bal Nègre and desire between women is very well discussed in Michel Lucey, "Simone de Beauvoir and Sexuality in the Third Person," using the methodology of literary pragmatics. As I wrote in chapter 2 above, the possibility of lesbian intersubjectivity (between Xavière and Françoise) is expressed in scenes like these (and there are others) where both women together look at other women, and assess them from a physical point of view. These involve both objectification and desire (obviously), but there's often, as here, a blurring or slippage between a competitive, comparing gaze, and desire tout court, that is between the desire to be and the desire to have what one is looking at. I suspect Beauvoir saw this as a stable feature of the condition of women: even Pierre's aggressively heterosexual sister Elisabeth indulges in it. 
I think a case can at least be made that Françoise takes a step, or a half-step, back from her own attraction to the "letting go" of the Bal Nègre and from the nexus of association that brings dark skin, and Xavière herself, closer to the animal kingdom than to civilization. Like Leiris in Africa, Françoise deplores her own ability to "let go," but in the end it is Françoise's consciousness, and consciousness tout court, that is to say, consciousness rather than the dark night of the Unconscious ("linfracassable noyau de nuit"), which must triumph, as a matter of life and death. If we want to talk about violence, it is the hyper-rational, over-civilized Françoise who suddenly becomes a killer. So the end of the book leaves me in a similar quandary as the end of Jirai cracher sur vos tombes: Wait, what? Where are my sympathies supposed to be here? What is this book trying to say?

The turning point, I think, comes when a friend, the dancer Paule Berger (who is a serious artist, as well as a woman with enviably fluid command of her body) invites the trio for an evening at the Spanish club: it reminds Françoise of trips she and Pierre used to take to Seville, and Paule notes with pleasure that there is no "faux pittoresque" - this is an authentic place where real Spanish people go. The musicians and especially the flamenco dancers are described in terms that recall the Arab dancer in the moorish café and the négresses of the Bal Nègre:

"These women are astonishing," said Françoise. "They have layers and layers of paint on their faces, and yet it doesn't make them look artificial, the face stays quite lively and animal."150

Xavière, as usual, is entranced: "Her cheeks were pink, she was no longer in control of her own face and her eyes followed the movements of the dancer, dazed with rapture." ${ }^{151}$ But when Françoise next looks at her, she has turned inward and is torturing herself, slowly and deliberately burning her hand with the glowing end of her own cigarette: "a bitter smile curled back her lips, an intimate solitary smile like the smile of a madwoman, the voluptuous tortured smile of a woman gripped by pleasure, one could hardly bear to look at her."152

150 “-Elles sont étonnantes, ces femmes, dit Françoise. Elles ont des couches de fard sur la peau et pourtant ça ne leur donne pas l'air artificiel, leur visage demeure tout vivant et animal" (L'invitée, 351).

151 "Ses pommettes étaient roses, elle ne contrôlait plus son visage et ses regards suivaient les mouvements de la danseuse avec un ravissement hébété" (L'invitée, 353).

152 "[U]n sourire aigu retroussait ses lèvres; c'était un sourire intime et solitaire comme un sourire de folle, un sourire voluptueux et torturé de femme en proie au plaisir, on pouvait à peine en soutenir la vue" (L'invitée, 354). 
This is Xavière's most "Nadja" moment. ${ }^{153}$ Pierre interprets the gesture as sacred: Françoise, however, has had enough. By the end of the chapter she will have decided, once and for all, that Xavière's "extase hystérique" reveals an "enemy presence," and that what she feels for Xavière henceforth will deserve the name of hate. ${ }^{154}$

But before Françoise reaches that point, the novel has had enough: the stage set falls apart and reality breaks through, in a long, very moving passage about the Fascist destruction of Spain.

A young woman stood up from a neighboring table and began to recite a Spanish poem in a harsh voice; a vast silence fell over the room and all eyes were fixed on her. Even without understanding the meaning of the words one was gripped to one's guts by this passionate tone of voice, this face distorted by pathos and ardor; the poem spoke of hatred and death, perhaps also of hope, and through its rising and falling tones of grief it was Spain, Spain torn to pieces, that was suddenly present to every heart. Gunfire and blood had driven the guitars, the songs, the gay shawls, and the fragrant flowers from her streets; the dancing-schools were in ashes, and bombs had burst the goatskins full of wine; in the gentle warmth of the evening, hunger stalked those streets, and fear. The flamenco, the intoxicating taste of the wine, were funereal echos of a dead past. ${ }^{155}$

Something is happening, and it's not about them. From this point on, the novel deserts fantasies of escape into Otherness for the morning-after bitterness of

153 There is even a reference to the beauty of ghosts (L'invitée, 360 ).

154 "[Cette] présence ennemie," L'invitée, 363 . In Françoise's final rage, which ends both the novel and Xavière's life, the myth of Xavière dies first: "the black pearl, the precious one, the spell-binder.Just a female [animal], she thought, passionately." [La perle noire, la précieuse, l'ensorceleuse, la généreuse. Une femelle, pensa-t-elle avec passion (L'invitée, 491).]

155 "À une table voisine, une jeune femme venait de se lever et elle commençait à déclamer d'une voix rauque un poème espagnol; un grand silence se fit et tous les regards se posèrent sur elle. Même si l'on ne comprenait pas le sens des mots, on était pris aux entrailles par cet accent passionné, par ce visage que défigurait une ardeur pathétique; le poème parlait de haine et de mort, peut-être aussi d'espoir, et à travers ses sursauts et ses plaintes, c'était l'Espagne déchirée qui se faisait soudain présente à tous les cœurs. Le feu et le sang avaient chassé des rues les guitares, les chansons, les châles éclatants, les fleurs de nard; les maisons de danse s'étaient effondrées et les bombes avaient crevé les outres gonflées de vin; dans la chaude douceur des soirs rôdaient la peur et la faim. Les chants flamencos, la saveur des vins dont on se grisait, ce n'était plus que l'évocation funèbre d'un passé défunt" (L'invitée, 362-63). 
adult life. Even Xavière feels it. Françoise tries to rescue the evening, sounding a false note of social good manners:

"We still have some time .... Paule was right, it's a good place."

Xavière let out a bizarre laugh.

"Don't you think we looked like American tourists visiting 'Paris at Night'? We sat down, off to the side, so as not to get dirty, we looked, without touching anything ..."

Pierre's face darkened.

"What, you would have liked us to snap our fingers and shout Olé?"156

(When Pierre was offered a wineskin to drink, and showed how to do it "properly," he choked and got wine all over his tie.) It is a good place, a "real" place, as Paule had promised; but they don't belong there.

A bit later, Françoise and Xavière return to the Moorish café, but it has lost its magic. "How sad it's become,' Xavière said."157 The danseuse is no longer beautiful.

"What big thighs she has," said Xavière with disgust, "she's gotten fat." "She was always fat," said Françoise.

"It's very possible," said Xavière. "It used to be so easy to dazzle me."158

Was this novel, then, sadly "of its time" in its images of people of color, and how it uses those images? Or is something more complex going on?

It does seem fair to say that both Beauvoir and Sartre in their early literary works made use of Blackness as an avant-garde and anti-establishment trope. So, in the early pages of La nausée, a nègre, dressed in yellow socks, a green hat,

156 “[N]ous avons encore du temps devant nous, c'est plaisant d'être ici. Elle se tournait vers Xavière: N'est-ce pas? Paule n'avait pas menti, c'est un bon endroit.

Xavière eut un rire bizarre.

- Vous ne trouvez pas qu'on a l'air de touristes américains en train de visiter 'Paris la Nuit.' Nous sommes installés un peu à l'écart, pour ne pas nous salir, et nous regardions, sans toucher à rien ...

Le visage de Pierre s'assombrit.

-Quoi! vous voudriez que nous fassions claquer nos doigts en criant: 'Ollé!' dit-il" (L'invitée, 361, ellipsis in original).

157 “-Comme c'est devenu triste, dit Xavière" (L'invitée, 422).

158 "-Comme elle a de grosses hanches, dit Xavière avec dégoût, elle a engraissé.

—Elle a toujours été grosse, dit Françoise.

-C'est bien possible, dit Xavière. Il en fallait si peu autrefois pour m'éblouir" (L'invitée, $425)$. 
and a raincoat, comes whistling around a streetcorner in the middle of the afternoon. Just then, a woman in a sky-blue coat is running backwards down the street, laughing, waving a handkerchief; right under an unlit street lamp, she crashes backwards into his arms. He almost seems like a refugee from an absurdist painting, an objective correlative for the narrator's state of mind, a sign that the perceptual world has gone slightly out out of whack (but only slightly). ${ }^{159}$ We've never seen these people before and we'll never see them again. The blues song "Some of These Days" will fill a similar gap at the end of La nausée: it is something from far, far outside that nonetheless, uncannily, penetrates the narrator to the core, in the way Leiris described the dancers of the Black Birds revue. Xavière certainly seems to participate in the same dynamic, as in an early scene when the two women are eating sandwiches in Xavière's room.

"Something very lucky just happened to me," said Xavière in a confiding tone.

"And what was that?" asked Françoise.

"The beautiful nègre dancer!" said Xavière. "He spoke to me."

"Be careful, or the blonde will scratch your eyes out," said Françoise.

"I passed him on the stairs, as I was going up with my tea and all my little packages." Xavière's eyes lit up. "He was so nice! he was wearing a light-coloured raincoat and his hat was pale grey, which goes so well with that dark skin. All the packages fell out of my hands. He picked them up and gave them back to me with a big smile and he said to me, 'Good evening, Mademoiselle, bon appetit."

"And what did you say back to him?"

"Nothing!" said Xavière, as if she'd heard something scandalous. "I ran away."

She smiled.

"He’s graceful like a cat, so unconscious, and so sly."160

159 “[T] out l'invraisemblable ... tout ce qui ne pourrait pas être cru dans les cafés, on ne le manque pas. Par exemple samedi, vers quatre heures de l'après-midi, sur le bout du trottoir en planches du chantier de la gare, une petite femme en bleu ciel courait à reculons, en riant, en agitant un mouchoir. En même temps, un Nègre avec un imperméable crème, des chaussures jaunes et un chapeau vert, tournait le coin de la rue et sifflait. La femme est venue le heurter, toujours à reculons, sous une lanterne qui est suspendue à la palissade et qu'on allume le soir. Il y avait donc là, en même temps, cette palissade qui sent si fort le bois mouillé, cette lanterne, cette petite bonne femme blonde dans les bras d'un Nègre, sous un ciel de feu" (Sartre, La nausée, 22).

160 "-Il m'est arrivé un grand bonheur tout à l'heure, dit Xavière d'un ton de confiance.

-Et quoi donc? dit Françoise.

—Le beau danseur nègre! dit Xavière. Il m’a adressé la parole. 
A better illustration of the failure of intersubjectivity Edward Hughes was warning about would be hard to find: Xavière has had a marvelous encounter; she hasn't had a human interaction, and seems barely able to conceive such a thing.

But there is more to this nègre than to La nausée's one-dimensional whistler: he speaks, though his speech is not "recognized." And we see more sides to him than Xavière does. It was Françoise who first mentioned him to Xavière in the early days of introducing her to the varied gens du quartier. (They were sitting with Pierre's sister Elizabeth in a place called the Prairie, which the older women frequented in their youth.)

"See that woman at the bar with the turned-up nose? She lives in my building. She slinks around the hallways for hours, in a sky-blue nightgown; I think she's trying to seduce the nègre who lives in the apartment above mine."

"She's not that pretty," said Xavière. Her eyes grew wide. "There's a brown-haired woman next to her who is really beautiful."161

The nègre doesn't have much of a speaking part in the novel, and he doesn't affect the plot, but he certainly (for lack of a better term) exists, for himself and for autrui. He lives in their building; he has friends, he has a girlfriend, maybe. At one point, Françoise sits down to work but has troubling concentrating:

- Prenez garde que la blonde ne vous arrache pas les yeux, dit Françoise.

- Je l'ai croisé dans l'escalier comme je remontais avec mon thé et tous mes petits paquets. Les yeux de Xavière s'illuminèrent. Qu'il était plaisant! Il avait un pardessus tout clair et un chapeau gris pâle, c'était si joli avec cette peau sombre. Mes paquets m'en sont tombés des mains. Il me les a ramassés avec un grand sourire et il m’a dit: 'Bonsoir, Mademoiselle, bon appétit.'

-Et qu'est ce que vous avez répondu? dit Françoise.

—Rien! dit Xavière d'un air scandalisé. Je me suis sauvée.

Elle sourit.

-Il est gracieux comme un chat, il a l'air aussi inconscient et aussi traître" (L'invitée, 169).

161 "Regardez au bar, la blonde au nez retroussé; elle habite dans mon hôtel; elle traîne pendant des heures dans les couloirs, en chemise de nuit bleu ciel; je crois que c'est pour aguicher le nègre qui habite au-dessus de ma tête.

—Elle n'est pas jolie, dit Xavière; ses yeux s'agrandirent. Il y a une femme brune à côté d'elle qui est bien belle" (L'invitée, 33-4). 
In the next room the nègre was giving the blonde hooker a tap-dancing lesson; a little Spanish woman who tended bar at the Topsy was with them, too. Françoise recognized their voices. ${ }^{162}$

On another occasion Françoise is sick in bed:

A door slammed on the landing and someone went down the corridor, slippers dragging; it must be the blonde hooker, who was just waking up; in the room above, the nègre's phonograph was softly playing "Solitude."163

This nègre is the subject of his own story, going on in another part of the building; he and his story are real in ways that don't depend on Françoise or Xavière. He's not a "symbol" of anything. (Perhaps he was based on a real person, like the intersexed refugee from Nazi Germany who also fascinates Xavière, and who shows up also in La force de l'âge.) In the end, how important is any of this? My answer has to be, it's actually not important at all, that's the point. A Black man lives in my apartment building, he's good-looking and kind of nice, and (unlike us) he has a phonograph. So what?

Now, obviously Sartre's thinking on race did not end with La nausée's whistling Negro. It would be possible to chart the shifts in his thinking about race by comparing the one-dimensional use of "local color" in his early fiction to the fullfledged anti-racism of La putain respectueuse: a melodrama, for sure, but a politically correct one. After a great deal of assistance from Richard Wright, that play's "nègre," though he still lacks a name, is certainly a man and not a myth. What I'm describing was in those years a common trajectory; and at the time of L'invitée, I think, Beauvoir was somewhere in the middle of it. If Linvitée cannot quite stage a passage from fascination to solidarity, at least it achieves the recognition of the racial other as an everyday human being, the recognition that is a necessary (though not a sufficient) ground for solidarity.

It's worth noting also that at least some of its earliest readers seem to have experienced L'invitée as a critique, rather than a celebration, of the avant-garde mystique it puts on display. To finish the passage I quoted earlier:

162 "Dans la chambre voisine le nègre donnait une leçon de claquettes à la putain blonde; il y avait avec eux une petite Espagnole qui était barmaid au Topsy, Françoise reconnaissait leurs voix" (L'invitée, 138).

163 "Une porte claqua sur le palier et quelqu'un traversa le couloir en traînant des savates, ça devait être la putain blonde qui se levait; dans la chambre du dessus, le phonographe du nègre jouait doucement: 'Solitude'" (L'invitée, 217). 
I anticipated that Adamov would be scornful. "So," I said to him, "have you seen it? A real novel with a beginning, a middle, and an end, do you utterly despise it?" He shook his head and looked at me gravely: "I wouldn't go that far. There's Xavière," he said. "There is Xavière." Because of Xavière, some of the habitués of the Café de Flore allowed for extenuating circumstances, but the great majority saw me in an unfavorable light; they complained to Olga, to Mouloudji: I had spoken in a very mediocre way of the Bal Nègre and its splendid animality. They did not find any of their myths in the novel, and the character of Françoise exasperated them. ${ }^{164}$

For the gens du Flore, as for Xavière herself, the novel's negrophilia (or whatever) does not go far enough; present-day readers may still feel it goes a bit too far. But the novel overall includes an awareness that there is something impossible, and also something vaguely sick, about making use of the Other in that way.

Within L'invitée these gens du Flore are associated with the "clan Péclard" that Gerbert has outgrown, ${ }^{165}$ and who are faintly suspicious of Pierre's experiments as a dramatist. ${ }^{166}$ Pierre's sister, Elizabeth, who incarnates artistic bad faith (and every other kind) describes herself as working in the surrealist tradition, but in a way that doesn't make much sense. ${ }^{167}$ To use Beauvoir's phrase from La force de l'âge, surrealism is the air the novel breathes. But both ethically and aesthetically speaking, it doesn't inhale.

164 “Je m'attendais au dédain d'Adamov. 'Alors, lui dis-je, vous avez vu? C'est un vrai roman avec un commencement, un milieu, une fin; ça vous déplaît bien fort?' Il hocha la tête, son regard s'alourdit: 'Pas tant que ça. Il y a Xavière, dit-il. Il y a Xavière.' À cause de Xavière, quelques habitués du Flore m’accordaient des circonstances atténuantes; mais la grande majorité me regardait d'un mauvais œil; ils se plaignirent à Olga, à Mouloudji: j'avais piètrement parlé du Bal nègre et de sa splendide animalité. Ils ne retrouvaient dans ce roman aucun de leurs mythes et le personnage de Françoise les exaspérait" (FA 637-38).

165 "[Gerbert] crossed the place Saint-Germain-des-Prés; [Pierre and Françoise] had arranged to meet him at the café de Flore; the spot amused them because they rarely went there, but as for him, he'd had it up to here with that whole enlightened elite." [Il traversa la place Saint-Germain-des-Prés; ils lui avaient donné rendez-vous au café de Flore; l'endroit les amusait parce qu'ils n'y venaient pas souvent, mais pour lui, il en avait pardessus la tête, de toute cette élite éclairée" (L'invitée, 317).]

166 See L'invitée, 112.

167 Pierre says she is right to give up realism in treating of war subjects. "Yes, you see the direction I'm working in now, she said. I'm trying to use the incoherence, the freedom, of the surrealists, but to remain in control." [Tu as vu, c'est dans ce sens-là que je travaille maintenant, dit-elle. J'essaye d'utiliser l'incohérence et la liberté des surréalistes, mais en les dirigeant" (L'invitée, 275).] 
As Doris Ruhe has discussed, Beauvoir left the drafting of literary manifestos to Sartre, and rarely even published books reviews. But L'invitée makes an implicit critique on the level of literary form. If Xavière is Nadja — and both Toril Moi and Susan Suleiman agree with the gens du Flore that she is ${ }^{168}$ - then L'invitée also explores what happens when the mysterious surrealist Other turns out after all to have une vie à elle and something to say. A surrealist "novel" is not really a novel as such: it never has more than one real character. Beauvoir would later explain, in her debate with Blanchot, her own sense that novels, at least good ones, operate dialectically, to provide the texture of the real. 169 She came to prefer L'invitée, and even more so Les mandarins, which stages an unresolvable political argument among many voices, to Le sang des autres, a "thesis novel" whose voice came too close to the didactic hectoring of the moral period essays with which she groups it. It would be a particular error, then, to take these café scenes, the image-repertory they make use of, the allusion to a common context, nexus, discourse, as "Beauvoir."

Insofar as L'invitée engages with race, it does so on the level of myth, not on the level of politics (or even ethics). But I think we must see it as reporting on the myths rather than sharing in or succumbing to them-much as Beauvoir will do in The Second Sex, where the question of "myth" is, obviously, extremely salient.

\section{Myths and Travels}

Thinking about the extremely diverse and heterogeneous material she discusses in The Second Sex under the heading of "mythes" reminds us that a myth is not just any old story that turns out not to be true: it is a culturally powerful

168 See Moi, "L'invitée: An Existentialist Melodrama," 123: "As the repressed unconscious, the mysterious $\mathrm{X}$ that always escapes a final, controlling interpretation, Xavière comes across as a traditional patriarchal representation of femininity in modernist garb: Xavière's closest fictional sister is surely André Breton's Nadja. Her power to stir and unsettle all fixed representations, to incarnate a certain revolutionary hysteria, may also awake associations from Freud's Dora to Marguerite Duras's Lol V. Stein. But where Breton and Durasin widely different ways, to be sure-valorize the transgressive, disordering power of their heroines, Beauvoir feels deeply threatened by it: not for her the delights of unconscious femininity or the jouissance of the disruptive sliding of the signifier." I would dissent only from the psychoanalyzing word "threatened" here: I think Beauvoir made this decision in full conscious lucidity.

169 This has been so well discussed by Ruhe ("Beauvoir, Blanchot, et Sartre"), Moi ("What Can Literature Do?"), Fallaize (The Novels of Simone de Beauvoir), and others that there is no reason to belabor it here. 
story that despite, or even because of, not being true has an enormous hold on people ("je sais très bien, mais quand même ..."). And it seems important that Beauvoir's take-down of Breton occurs at toward the end of her long section about "myths of woman." When second-wave American feminist criticism picked up on the methodology (so to speak) of The Second Sex, they (we) tended to speak of "images of women" in works of art by men. But there's a difference. If Beauvoir had just been looking for "negative images" of the female body in surrealist and post-surrealist literature, there are actually plenty of examples from Leiris's literary work that could have given Breton a run for his money. She does draw on his autobiographical L'âge d'homme for some fairly striking descriptions of the female body; in the course of discussing how Christian "puritanism" has afflicted men's view of sexuality, she quotes Leiris's description of his symptom: "I have a tendency to consider the feminine organ as a dirty thing or a wound, not less attractive though for that, but dangerous in itself, as everything that is bloody, viscous, and contaminated." 170 However, she makes an interesting distinction.

Myth must not be confused with the grasp of a meaning [signification]; meaning is immanent to the object; it is revealed to consciousness in a living experience, whereas a myth is a transcendent Idea that escapes any conscious awareness. When Michel Leiris in L'âge d'homme describes his vision of female organs, he shows us meanings and does not develop any myth. Wonderment at the sight of a woman's body or disgust for menstrual blood are apprehensions of a concrete reality. There is nothing mythical in the experience of uncovering the voluptuous qualities of womanly flesh, and one does not turn the experience into myth by trying to express these qualities through similes, as flowers or as pebbles. But to say that Woman is Flesh, to say that Flesh is Night and Death, or that she is the splendor of the Cosmos, is to leave earthly truth behind and fly off into an empty sky. After all, man is also flesh for woman, and woman is more than a fleshly object; and the flesh takes on singular meanings, for each person, in each encounter. ${ }^{171}$

170 "Michel Leiris écrit dans L'âge d'homme: 'J'ai couramment tendance à regarder l'organe féminin comme une chose sale ou comme une blessure, pas moins attirante pour cela, mais dangereuse en elle-même, comme tout ce qui est sanglant, muqueux, contaminé'” ( $D S$ 1:279). The other example Beauvoir gives is from Faulkner's Light in August.

171 "Il ne faut pas confondre le mythe avec la saisie d'une signification; la signification est immanente à l'objet; elle est révélée à la conscience dans une expérience vivante; tandis que le mythe est une Idée transcendante qui échappe à toute prise de conscience. Quand dans L'âge d'homme Michel Leiris décrit sa vision des organes féminins, il nous livre des 
I don't find this distinction easy to understand, to be honest. But the point seems to be that not every negative apprehension of the female body, and not every use of the female body as metaphor, is a problem for Beauvoir. Leiris in her example does those things, but as part of his attempt to chronicle and analyse his own singular subjective experience: we might say he doesn't theorize, or he doesn't totalize, his experiences. He remains a good phenomenologist; what he uncovers in himself is often as tough to take for the reader as it was and is for him (L'âge d'homme is called an "essai-martyr," remember). ${ }^{172}$ Perhaps Beauvoir's own engagement with images of women we find troubling can be understood in the same way.

Or perhaps the distinction between developing a myth and reporting on one is not, in the end, as clearcut as she (and we) would like such things to be.

Fall 2010. I am sitting on the floor in the middle of the night, surrounded by a chaos of books and papers relating to Michel Leiris. I am supposed to be packing for my sabbatical trip. Instead, I am watching King Vidor's 1929 film, Hallelujah. (It needs to go back to Netflix, like, yesterday.) The film seems to have been enormously important to Leiris and Beauvoir both, that is a point of

significations et n'élabore aucun mythe. Lémerveillement devant le corps féminin, le dégoût du sang menstruel sont des appréhensions d'une réalité concrète. Il n'y a rien de mythique dans l'expérience qui découvre les qualités voluptueuses de la chair féminine et on ne passe pas au mythe quand on tente de les exprimer par des comparaisons avec des fleurs ou des cailloux. Mais dire que la Femme, c'est la Chair, dire que la Chair est Nuit et Mort, ou qu'elle est la splendeur du Cosmos, c'est quitter la vérité de la terre et s'envoler vers un ciel vide. Car l'homme aussi est chair pour la femme; et celle-ci est autre qu'un objet charnel; et la chair revêt pour chacun et dans chaque expérience des significations singulières" ( $D S$ 1:398).

172 How Beauvoir could, after reading that intimate exploration of a man's difficulties in coming to sexual maturity, have concluded that male adolescence was easy, is one mystery I cannot fathom.

Leiris makes two other appearances in The Second Sex. In a discussion about the powers (beneficent and/or threatening) given to the Mother, she quotes in a footnote a long section of his disturbing poem "La mère," commenting on "why rebels attack the motherfigure so furiously; in scorning her, the appointed guardian of custom and morality, they refuse the pre-given values society seeks to impose." [[C]'est pourquoi aussi tous les révoltés s'acharnent sur la figure de la mère; en la bafouant, ils refusent le donné qu'on prétend leur imposer à travers la gardienne des mœurs et des lois ( $D S$ 1:286).] And in the section on "Formation," when explaining what is terrifying of a girl's first sexual experience, she reaches for his bull-fighting metaphor of the bed as a "terrain de vérité" literally a "place of truth," this refers to the part of the ring where either the bull or the matador will die (DS 2:158). 
connection between them: I'm looking for a neutral point to judge their response. But I can't make head or tail of what's been written about the film. Some commentators describe a stunningly beautiful, dignified evocation of African American life, others find an embarrassing collection of racist stereotypes.

So I watch it. And I still can't make up my mind. I watch the commentary that comes with it on the DVD: the scholars, who seem unusually ill at ease, can't seem to make up their minds whether the film is retrograde or revolutionary, either. (The film itself seems unsure whether it is a documentary or a melodrama.) Outdated ethnocentrism? Lost beauty? It is very compellingly both. (Could I prove that? How would one begin to go about proving such a thing?) What I can say is that it is definitely still worth watching.

There's a scene in Les mandarins where Paule rather pathetically asks Anne, as they are getting ready for a high-society party, whether she should wear her African necklace. Anne thinks, you know, probably not: the necklace represents the defiance/eroticism of a previous era, which Paule is vainly trying to recapture. ${ }^{173}$ Henri in that novel's opening pages is longing for the East, to feel the sun on his face as he used to do before the war ... and he, too, attempts to recapture the past by locating it east and south (Portugal), and going to Portugal with a different, younger woman, Nadine. But it doesn't work. Neither Henri nor Nadine can avoid noticing, first the abundance of food (compared with the wartime austerity of Paris) and then - worse - that amid this plenty most of the Portuguese, too, are starving. Henri's vacation time is swallowed up by the very sort of political conversation he had hoped to escape. ${ }^{174}$

The political commitment to which Henri returns at the end of that book is very much anti-colonial. In L'invitée the East and South are still, to some extent, barely distinguished, mysterious and alluring realms of desire; by the time of Les mandarins, the colonized world has become a political sphere about which Henri informs himself, with respect to which he takes on certain political responsibilities. So to my mind, as with Leiris, the question is, not whether the initial sources of Beauvoir's interest were pure, but what she made of them.

It would be fair to say that when she embarked for the United States, it was not the land of White but the land of Black that she contemplated seeing with the greatest fascination, as though she were about to take a trip to the bottom of the Unconscious.

173 Les mandarins, 2:80.

174 Les mandarins, 1:138-58. 
So for us America was first, a saraband of images, on a background of raucous voices and jagged rhythms: the trances and dances of Hallelujah, the buildings reared up against the sky, prisons in revolt, high smokestacks, strikes, long silky limbs, locomotives, planes, wild horses, rodeos. When we looked away from this bric-à-brac, we thought of America as the country where capitalist oppression was triumphing most detestably; we hated it for exploitation, unemployment, racism, lynchings. Nonetheless, beyond good and evil, life there had something giant and wild that fascinated us. ${ }^{175}$

Note, however, that Beauvoir retrospectively characterizes what she anticipated seeing as a "sarabande des images" and as "ce bric-à-brac." It seems like the trip to America - the real trip to the real United States, which Boris Vian by the way never took-operated as a kind of cure "dans le vrai," and was theoretically and politically productive. ${ }^{176}$

In L'Amérique au jour le jour 1947 Beauvoir records a long conversation she and Wright had, while they were eating barbecue in Harlem, where Wright was very critical of whites who "go to Blacks" in order to appreciate their supposedly greater musical abilities, their sensual power, and so on. Wright uses the language of psychology (projection, neurosis) to condemn even such wellmeaning "amis des noirs" as the jazz musician Mezz Mezzrow for missing the point about racial oppression.

Wright deplores, among many other things, the sort of attraction many whites in the North and especially in New York feel with regard to Blacks. They define them as the antithesis of American civilization: magnificently gifted in music and dance, rich in animal instincts and especially an extraordinary sexual potency, insouciant, unconscious, dreamers, poets, open to religious sentiments, undisciplined, child-like, such is the

175 "Ainsi l'Amérique, pour nous, c'était d'abord, sur un fond de voix rauques et de rythmes brisés, une sarabande d'images: les transes et danses des noirs d'Hallelujah, des buildings dressés contre le ciel, des prisons en révolte, des hauts fourneaux, des grèves, de longues jambes soyeuses, des locomotives, des avions, des chevaux sauvages, des rodéos. Quand nous nous détournions de ce bric-à-brac, nous pensions à l'Amérique comme au pays où triomphait le plus odieusement l'oppression capitaliste; nous détestions en elle l'exploitation, le chômage, le racisme, les lynchages. Néanmoins, par-delà le bien et le mal, la vie avait là-bas quelque chose de gigantesque et de déchaîné qui nous fascinait" (FA 162).

${ }_{176}$ The closing scene of La nausée, too, evokes New York in a way that would no longer be possible once Sartre had been there. 
conventional image of Blacks they are happy to hold. And they "go to Blacks" because they have projected onto them what they themselves wish to be and are not; but the most fascinated are those who feel themselves most profoundly deficient; so that these "nigger-lovers," as southerners would call them, are for the most part bitter, sick, neurotic, ravaged by inferiority complexes. That Mezzrow goes to live in Harlem and systematically prefers Blacks to whites stems from this attitude; Wright finds it harmful, because it hangs onto the gulf between Blacks and whites. The evident differences between the two castes come from differences in historical, economic, social, cultural situation, which could—at least theoretically—be abolished. But this is one of the truths which even the most well-meaning Americans do not want to hear. ${ }^{177}$

Wright's view here is quite close to Fanon's in the opening pages of Peau noire masques blancs: "To us, the man who adores the Negro is as 'sick' as the man who abominates him." ${ }^{178}$ It was a lesson she'd take fully on board.

177 "Tout en mangeant des côtes de porc et des frites, buvant de l'eau-car ces endroits modestes n'ont pas la licence qui permet de vendre des spiritueux — nous sommes naturellement ramenés à discuter encore de la question noire. Wright déplore entre autres le genre d'attirance que beaucoup de blancs dans le Nord et spécialement à New York éprouvent à l'égard de noirs. Ils les définissent comme l'antithèse de la civilisation américaine: magnifiquement doués pour la musique et la danse, riches d'instincts animaux et entre autres d'une extraordinaire puissance sensuelle, insouciants, étourdis, rêveurs, poètes, ouverts au sentiment religieux, indisciplinés, enfantins, telle est la conventionnelle image qu'ils se font volontiers des noirs. Et ils 'vont aux noirs' parce qu'ils ont projeté en eux ce qu'ils souhaiteraient être et ne sont pas; mais les plus fascinés sont ceux qui sentent en eux-mêmes les plus profondes déficiences; si bien que ces nigger-lovers, comme les appelleraient les gens du Sud, sont pour la plupart des aigris, des malades, des individus névrotiques, des faibles rongés de complexe d'infériorité. Que Mezzrow aille vivre à Harlem et préfère systématiquement les noirs aux blancs relève de cette attitude: Wright la trouve néfaste, parce qu'elle tend à maintenir l'existence d'un fossé entre les noirs et les blancs. Les différences évidentes entre les deux castes viennent de différences de situation historique, économique, sociale, culturelle qui pourraient—du moins théoriquementêtre abolies. Mais c'est là une des vérités dont les Américains blancs, même les plus bienveillants, n'aiment pas se laisser convaincre" ( $\left.A J 485^{-86}\right)$.

178 "Pour nous, celui qui adore les nègres est aussi 'malade' que celui qui les exècre" ( $P N M B$ 6; $B S W M$ 2). The passage continues, "Conversely, the Black man who wants to turn his race white is as miserable as he who preaches hatred for the whites. In the absolute, the Black is no more lovable than the Czech, and really, it's time to let the man go." [Inversement, le Noir qui veut blanchir sa race est aussi malheureux que celui qui prêche la haine du Blanc. Dans l'absolu, le Noir n'est pas plus aimable que le Tchèque, et véritablement il s'agit de lâcher l'homme ( $P N M B$ 6; BSWM 2, translation altered).] We should hear resonances of the nursery rhyme - "if he hollers, let him go" — which Chester Himes took as title for his novel. 
In short, two notions of authenticity were in play in the post-war period: an existentialist one, and one around race. My unsurprising conclusion is that these were both productively and problematically interwoven, and that it seems to have taken Beauvoir a certain amount of time to sort them out as she moved toward a position of solidarity with the international anti-colonial movement that included both Fanon and Wright.

\section{9}

Meanwhile, Back in New York...

What Les Temps Modernes valued about Richard Wright's analysis was however increasingly devalued back home. The first American writer of color to really be a best-seller, he quickly fell from critical favor in the United States, and for several decades his work, especially the writing he did after he emigrated to Europe, received little attention or was disparaged. Michel Fabre, Wright's French biographer, was surprised, when he began his research in the early 196os, that many of Wright's books, though readily available in French translation, had gone out of print in the United States, and that the American academics he met with in the course of his research were dismissive. ${ }^{179}$ The tendency to see Wright as a pathetic, superseded figure whose late work was ruined by going to Europe and encountering a philosophy he couldn't understand, while losing touch with his "roots" and his "material" (the "folk"), persisted for a long time, as both Gilroy and Simons note. ${ }^{180}$ In 1991 the Library of America brought out the "definitive" edition of his works, clearly intended to rehabilitate and honor Wright by restoring material cut by original publishers as too "daring"; the editor, Arnold Rampersad, also chose to include an early unpublished novel, Lawd Today, which is indeed stunningly good and shows Wright's connection to naturalist writers of the Chicago school (including one Nelson Algren). But the bias against Wright as a political thinker continued: almost nothing was included from his European period, none of the essays and travel writing from his internationalist political phase, and none of his writing about Africa. ${ }^{181}$ This presents a seriously skewed picture and (whatever one

\footnotetext{
179 Michel Fabre, The Unfinished Quest of Richard Wright. He discussed this surprise in the preface to the first (1973) edition, which appears in the second (1993) edition as xxi-xxii.

180 Perhaps this relates to a tendency to see existentialism as a set of faded and pathetic oncetrendy dogmas which "we," having had the benefit of post-structuralism, now see beyond. As must be clear by now, I don't agree with that judgment.

181 Gilroy discusses Rampersad as an advocate for the American Richard Wright and connects this to a particular idea of "authenticity," which Gilroy wants to call into question (The Black Atlantic, 153-57). According to Gilroy, Wright's "Blueprint for Negro Writing"
} 
thinks of Wright) it is surely irresponsible to pass over these omissions in silence. Louis Menand's New Yorker review of Rampersad's selection magnified and broadcast Rampersad's erasure of Wright's politics by describing Wright's development as "Nietzschean" and basically deploring the "protest" element of his work. ${ }^{182}$ I am trying not to say "It is no accident that" the Library of America edition does include his powerful indictment of the Communist party in American Hunger. ${ }^{183}$ (There's no clearer give-away of what used to be called vulgar Marxism than a sentence that starts, "It is no accident that," is there. And the Cold War is over. Isn't it?) But if Wright's non-fiction prose works, like The Color Curtain and Black Power, which combine "travel writing" with theory and political analysis, were until recently no better appreciated by American audiences than L'Amérique au jour le jour 1947 was, perhaps this was for some of the same reasons. Fortunately, more recent scholarly work has appeared that does take Wright and his ideas seriously, both politically and philosophically, and that sees him, and other writers about the Black experience in the United States, as part of Existentialism with a capital E. ${ }^{184}$

But wait a minute, you say: wasn't Richard Wright a terrible misogynist?

(1937) "only implies what would later become one of his favorite themes, namely that differences between the groups we know as races are associated with the repression of differences within those races" (154); "an elaborate body of philosophically-informed reflection on the character of western civilization and the place of racism within it ... [is] filtered through the mesh provided by his combination of fervent anti-communism and passionate anti-capitalism" (155).

182 Louis Menand, "The Hammer and The Nail."

183 Something similar might be said about the missing Red chapter from most people's understanding of Langston Hughes. Might there be more to the fact the best biography of Wright to date was written by a French man than the "Jerry Lewis problem"?

184 The silence Fabre complained of is over, and he deserves some of the credit; it was he, for instance, who organized the archive, and he discovered the manuscript of what became American Hunger and worked with Ellen Wright to get it into print. Among the excellent work now ongoing I'd single out the work of Abdul JanMohammed (particularly The Death-Bound-Subject: Richard Wright's Archaeology of the Dream), and two edited collections, James B. Haile III, Philosophical Meditations on Richard Wright and William E. Dow, Alice Mikal Craven, and Yoko Nakamura, Richard Wright in a Post-Racial Imaginary, for their attention to issues discussed here. (I was initially dubious about the latter anthology's term "post-racial." As used here, though, the muting of a relentlessly binary idea of race does not remove the critique of domination, but rather complicates it, and makes class and also geography more visible.) Also interesting is Alice Mikal Craven and William E. Dow, eds., Richard Wright: New Readings in the 21st Century. See also now Jane Anna Gordon and Cyrus Ernesto Zirakzadeh, eds., The Politics of Richard Wright: Perspectives on Resistance, and Lori Marso, Politics with Beauvoir: Freedom in the Encounter, 122-147, which includes extensive discussion of Wright's European and African travels, and persuasively puts his book 12 Million Black Voices in conversation with The Second Sex. 
The question of Wright's "misogyny" is not one I can fully discuss here, much less settle. How can we balance his support of Gwendolyn Brooks with his conspicuous lack of support for Zora Neale Hurston? Gilroy, who is a vocal member of the "not a misogynist" camp, notes that Wright began his speech at the first Présence Africaine congress by lamenting the absence of women from the event. ${ }^{185}$ Barbara Foley has discovered in Wright's papers an unpublished manuscript from the early 1940s; one draft, for which he did research with domestic workers, dealt with the difficult life of a woman trafficked from South to North; but Foley's description, while making it clear that this text (which explores fascism's appeal to the oppressed) does give voice to some feminist ideas, also makes it sound unlikely that publication of "Black Hope" would settle the "misogyny" debate one way or the other. ${ }^{186}$

But was Wright mistaken in preferring Brooks to Hurston, a complex figure whose contrarianism went so far as refusing to support Brown v. Board of Education? ${ }^{187}$ Hazel Carby, who first became well-known for a piece titled "White Woman Listen," thinks Wright had a point:

In returning to and recreating the moment of her childhood, Hurston privileges the nostalgic and freezes it in time. Richard Wright, in his review of Their Eyes Were Watching God, accused Hurston of recreating minstrelsy. Though this remark is dismissed out of hand by contemporary critics, what it does register is Wright's reaction to what appears to him to be an outmoded form of historical consciousness. Whereas Wright attempted to explode the discursive category of the Negro as being formed, historically, in the culture of minstrelsy, and as being the product of a society structured in dominance through concepts of race, Hurston wanted to preserve the concept of Negroness, to negotiate and rewrite its cultural meanings, and, finally, to reclaim an aesthetically purified version of blackness. The consequences for the creation of subaltern subject

185 Gilroy, The Black Atlantic, 176. Wright said, apparently, that "black men will not be free until their women are free," and called for an "effective utilization of negro womanhood in the world to help us mobilize and pool our forces," which is terrific, except for the possessive pronoun.

186 Barbara Foley, "A Dramatic Picture of Women from Feudalism to Fascism: Richard Wright's Black Hope." According to Foley's article, the Wright estate was opposed to the idea of publication at that time.

187 See Glenda R. Carpio and Werner Sollors, "The Newly Complicated Zora Neale Hurston," and Hazel Carby, "The Politics of Fiction, Anthropology, and the Folk: Zora Neale Hurston." 
positions in their works are dramatically different. The antagonism between them reveals Wright to be a modern, and leaves Hurston embedded in the politics of Negro identity. ${ }^{188}$

Perhaps what we're seeing isn't "misogyny" but a genuine difference of opinion. What's at stake between them isn't (or isn't just) gender politics, but (also) a disagreement about how to value and advance Black culture, comparable to the different views about négritude offered by Léopold Senghor on the one hand and by Fanon and Césaire on the other.

The Gwendolyn Brooks poem that appeared, thanks to Wright's mediation, in the very first issue of Présence Africaine turns out to be "The Ballad of Pearl May Lee," an angry mock-joyful poem in which a dark-skinned Black woman says she is glad that her husband is being lynched, for going along with a white woman who seduced him and then cried rape. ${ }^{189}$ (The refrain is, "You had it coming surely.") If there ever was a poem that showed why it was hasty to collapse the subject positions or "standpoints" of Black women and Black men, or of Black women and white women, this would be it; considering that Wright himself was married to a white woman, his support for this (stunning) poem and poet speaks strongly in favor of his awareness that the issues involved were complex, and that the claims involved were incommensurable and perhaps finally irreconcilable.

Wright would also have been very familiar with debates within the Communist Party of the United States on "the woman question." As with race issues, the CPUSA was for a time more progressive about women's issues than mainstream America; Kate Weigand has shown that the contribution of Old Left women to second-wave feminism was long understated, mainly due to McCarthyism. ${ }^{190}$ Barbara Foley's archival work has also discovered that Wright owned Mary Inman's “In Woman's Defense," an important analysis of women's domestic labor which synthesized feminism and Marxism; the Party leadership later attacked it (and Inman). Foley and Gilroy both point to one of the stories in Wright's Eight Men, in which a man cross-dresses to get work as a maid and discovers that the work is physically too hard for him (shades of The Salt of the Earth!) and that he is vulnerable to sexual harassment. None of this

\footnotetext{
188 Ibid., 79 .

189 The poem also appears in Brooks's A Street in Bronzeville and is reprinted in Blacks, the fullest available collection of her work, 6o-63.

190 See Kate Weigand, Red Feminism: American Communism and the Making of Women's Liberation.
} 
helps us know how to read the "existential" violence against women that is central to much of Wright's fiction. ${ }^{191}$ All I can do here is suggest that posing the question as "misogynist, yes or no" obscures more than it illuminates.

But how does it happen that "Richard Wright, Political Thinker" and "The American Richard Wright" seem to be two different people?

The urbanely condescending tone of Menand's appraisal of Wright struck me as depressingly familiar. Though he might deny this, Menand is in many ways the heir of the very people who most annoyed Beauvoir on her first visit to New York City: a loose group literary historians refer to as "The New York Intellectuals," who first gathered around the Partisan Review. ${ }^{192}$ Meeting them at a party, Beauvoir describes them as "the editorial team of a review that calls itself leftist and avant-garde, whose aggressive tone surprises me.... They hate Stalinism with a passion that reveals them as former Stalinists." ${ }^{193}$ In a letter to Sartre, she was even franker: "They would burn the world to ashes to keep their stupid rag alive."194 They first take her to task for Merleau-Ponty's article, "Le yogi et le prolétaire," which had just appeared in Les Temps Modernes:

Perhaps because we were drinking, we didn't weigh our words very carefully. My remarks were judged worthy of an agent of the Soviet Secret Police; but it would be easy to mistake these free spirits for American imperialists. Halfway through the conversation the tall, insolent young man declared, "After all, it wasn't the Russians who sent you food to live on; it's America who created the UN Relief Agency." If even these socalled leftist intellectuals are so proud of the tinned milk their government sends, how can we be surprised by the arrogance of the capitalist press, by the tone of condescension toward France I've observed pretty much everywhere, which is beginning to annoy me?195

191 See Jan-Mohammed, The Death-Bound-Subject, for a fuller discussion.

192 See Louis Menand, "Browbeaten: Dwight MacDonald's War on Midcult." I'm aware as I write this that the term "New York Intellectuals" may have little current resonance beyond the Upper West Side. But if you have seen Margarethe von Trotta's film about Hannah Arendt, you have met these people.

193 “[L]'équipe d'une revue qui se dit de gauche et d'avant-garde et dont l'agressivité me surprend.... Ils haïssent le stalinisme avec une passion qui me fait comprendre que ce sont d'anciens staliniens" (AJ59-60). See also 45, 59-60, and 78-81, about American literature.

194 "Ils incendierait le monde pour que leur mauvais torchon vive" (Lettres à Sartre, 296).

195 "Je pense que l'alcool aidant nous mesurons mal nos paroles; il paraît que mes propos sont dignes d'un agent du Guépéou: mais on prendrait facilement ces esprits libres pour des impérialistes américains. Le grand jeune homme insolent déclare au milieu de la conversation: 'Ce ne sont quand même pas les Russes qui vous envoient de quoi manger; c'est l'Amérique qui a crée l'UNRA.' Si même les intellectuels dits de gauche sont si fiers des 
In a long discussion toward the end of L'Amérique au jour le jour 1947, Beauvoir shows her detailed understanding of the different tendencies among this group - for instance, around the time of her visit, Dwight Macdonald and Mary McCarthy had broken off to found a journal called politics, which was a bit further left. Not all of the New York Intellectuals would become as conservative as Norman Podhoretz or Sidney Hook; the New York Review of Books, which the group would found in 1963 , was always recognizably more openminded than Commentary; their direct descendants include Susan Sontag as well as Norman Mailer. ${ }^{196}$ But Beauvoir's overall diagnosis of the dangers implicit in their "pessimistic individualism," as part of the "parti pris of inertia"197 in the face of McCarthyist sabre-rattling that she saw all across the United States, especially on college campuses, is borne out by a reading of the symposium "Our Country and Our Culture" organized by the Partisan Review in $195^{2}$. As it happens, "vulgar Marxist propaganda" claims that the CIA itself was behind many of their institutions, such as the Congress for Cultural Freedom and the journals Encounter, Perspectives USA, and Preuves, later turned out to be literally true. ${ }^{198}$

It is very difficult to explain why this group matters to anyone who doesn't already think so; in retrospect, their nasty internal quarrels seem unbelievably

boîtes de lait condensé que leur gouvernement nous dispense, comment s'étonner de l'arrogance de la presse capitaliste, de ce ton de condescendance que j'ai observé un peu partout à l'égard de la France et qui commence à m'exaspérer?" (AJ6o-1).

196 Some would see the New Yorker of the 1940s and 5os as part of this "group" and others would disagree. When Arendt's husband says in von Trotta's movie, "Hannah, das kannst du im New Yorker nicht sagen!" (Hannah, you can't say that in The New Yorker!), he's expressing a view that the mass-market magazine was somehow gentler and more "midcult" (Macdonald's word) than the others. But Hannah could, and Hannah did. The New Yorker also dedicated a whole issue to John Hersey's Hiroshima.

Despite their lack of unanimity on just about any question, and the sheer nastiness of some of their internal bickering, I can't help agreeing with Beauvoir that the group shares a particular subjectivity, or self-concept, or ethos: taking principled left positions about certain things makes it unnecessary to examine one's complicity with the dominant culture in other respects. Of course it's easier to spot this in someone else than in oneself. "And this is hell, nor are we out of it."

197 "Individualisme pessimiste," "parti pris de l'inertie" (AJ 474, 472). "Parti pris" can mean a bias, or a prejudice, but it is also used for someone who has taken a theoretical stand. Beauvoir here means both, I think: like the serious man, the Americans she's talking about have turned their inclination to passivity into a system of life.

198 The literature on the New York Intellectuals is vast, but see Alan Wald, The New York Intellectuals: The Rise and Decline of the Anti-Stalinist Left from the 1930s to the 1980s, and Frances Stonor Saunders, The Cultural Cold War: The CIA and the World of Arts and Letters. For a discussion of how Cold War categories continue to shape intellectual debates, see Michael Denning, Culture in the Age of Three Worlds. 
petty, and they can't possibly actually matter as much as they thought they did. But the reach of the Partisan Review was broad. ${ }^{199}$ In spite of the 196os, which most of them astringently deplored, somehow such "intellectual life" as there is in the United States outside universities still seems marked by the terms they set. For me, Menand's faintly genteel distaste for protest retains the ring of Lionel Trilling's The Liberal Imagination (1950), smug in its claim to articulate progressive values through the Great Tradition and yet equally proud of its distance from anything that looks like it might genuinely upset the applecart. Garcia gives a very clear account of how the New York Intellectuals used a language of psychological "maturity" and aesthetic "complexity" to explain first their own turn away from the radicalism of the 1930s and later their disdain for the unwashed youth movements of the 196os. For instance, despite their early support for James Baldwin - they particularly liked "Everybody's Protest Novel," his attack on Richard Wright - they largely missed the boat when it came to Civil Rights. ${ }^{200}$ Hannah Arendt's failure to see the forest for the trees in her piece on Little Rock, the frank racism of Saul Bellow's Mr. Sammler's Planet, Norman Mailer's ghastly "White Negro" essay, are symptomatic. ${ }^{201}$ Some of them joined in protesting the war in Vietnam (Mary McCarthy's hard-hitting reportage on what she saw there is still worth reading), but fighting racial injustice was not part of their agenda. Their influence on the "consensus" view that came to dominate the nascent field of American studies was especially profound. 202

I'm too much of a "Tenured Radical" (as their heirs would put it) to be a "New York Intellectual." Still—full disclosure here—it's hard for me to imagine

199 For instance, Stanley Cavell notes in his autobiography that "[t]he legacy, if I may call it that, of anti-Stalinist socialist aspirations living somehow with a commitment to high modernism, is one for which I am permanently grateful" (Little Did I Know: Excerpts from Memory, 231). The word "somehow" is characteristically apt.

200 They soured on Baldwin, too; by 1957, Commentary was accusing Baldwin of "an anachronistic attitude toward race" (Garcia, Psychology Comes to Harlem, 163).

201 An analysis of the parallels between Mailer's "White Negro" and Firestone's Dialectic of Sex might be illuminating. It was Bellow who famously asked, "Who is the Tolstoy of the Zulus?" See also Barber, "Phenomenology and the Ethical Basis of Pluralism." Barber makes an interesting argument that while the two different philosophical approaches taken by Beauvoir and Arendt "cashed out" differently in terms of their ability to read the immediate situation, both are ultimately necessary to a fully adequate solution of realworld problems. See also now Gines, Arendt and The Negro Question.

202 See Geraldine Murphy, "Romancing the Center: Cold War Politics and Classic American Literature," and Michael Denning, Culture in the Age of Three Worlds. 
life without the New Yorker and the New York Review of Books; and as time wears on it gets harder to extricate myself from that discourse of "maturity." Every time one finds oneself saying (internally) "such and such a group has a valid point, of course, but they go too far" or " $\mathrm{X}$ is right but does she have to say it like that?" or "by demanding Y before the time is ripe they are hurting their own cause..." Or: "existentialism had its impact, certainly, but it's not really philosophy, it's something people outgrow after their sophomore year, like Ayn Rand." Or: "Bernie Sanders, now that would really be something. But he's a throwback, he couldn't possibly win." And there's often more than a grain of truth in these thoughts, isn't there? ${ }^{203}$ But there's also a whiff of bad faith, a nagging sense that perhaps these, too, are self-fulfilling prophecies. I'll put my cards on the table: when Beauvoir speaks of the American "parti pris d'inertie," I think she really had their number, and ours as well. The insouciance about the coming of war with the USSR that she saw in American college students, that Sartre found in his discussion with a Ford Foundation official: "But you have no common border, where will you fight?" "Oh, we will fight them in Europe."204 In the end, they fought them in Asia. And I remember going into the bar on 9/11 and hearing Don Henley's "The End of the Innocence" and thinking well, you can call it innocence if you like...

Beauvoir says thousands and thousands of Americans don't fit the picture she is drawing, and she has plenty of negative things to say about French intellectual and public life. But I can't help be stung by some of what she says, myself. Is it is the sting of non-recognition or the sting of recognition? ${ }^{205}$ bell hooks once visited the campus where I work, and I wrote down something she said in her closing remarks to the students: "You tell me that you live in a free country, and then you say that you can't say what you really think because your friends in the fraternity and sorority won't like you any more."

203 "Possibly by the time you read this, the last statement will already have proven right," I wrote at this point, in the summer of 2016. 2017: well, yes, no kidding. 2019: or maybe not?

204 "Au cours d'un déjeuner, le directeur des Public relations de Ford avait évoqué avec bonne humeur la prochaine guerre contre l'URSS. 'Mais vous n'avez pas de frontière commune, où se battra-t-on?' avait demandé une journaliste du PC. 'En Europe,' répondit-il avec naturel" (FCh 1:55).

205 Patriotism surfaces embarrassingly at odd moments. Is any version of national character offensive? It is bound to give offense, certainly, but that is not my question. Is this something one should ethically or politically forbid oneself? But it's really hard, especially when you're traveling. (How stupid they think us. On the other hand, how right they are.) 
In any case, the fact that the New York Intellectuals were not able to find common ground with Les Temps Modernes, and vice versa, says a great deal, not just about the context of Wright's American reception, but also Beauvoir'sincluding the American reception of The Second Sex, and its repercussions for second-wave American feminism, which is my reason for dwelling on it here. ${ }^{206}$

Beauvoir's critique of the American paradox went far beyond that group. In New Mexico she tells us what the headlines say about what Truman is doing, and then notices how few people (other than some French people she happens to meet on the way) seem to be talking about it. She refers twice to a comment made to her by someone at the New York Times:

[T] he top manager leans back in his swivel chair; he looks down on me ironically, from the height of his own power and of American power generally. So France is amusing itself now with existentialism? Of course, he knows nothing about existentialism, his contempt is aimed at philosophy in general, and even more broadly at the sheer effrontery of an economically impoverished country claiming to think; isn't it laughable to go on thinking when one hasn't the advantage of running a major American newspaper, which anyhow renders thinking unnecessary? "Yes," says he, "in France you pose problems, but you don't solve them. Here, we don't pose them, we resolve them." The creaky armchair swivels back and forth....207

"In France, you pose problems; in America, we resolve them." For me this rhymes with a throwaway comment Paul de Man made in 1986, which stuck in my head: "in Europe, one is of course closer to political and ideological

206 I'll have some more examples when I come to discuss Beauvoir's writing about China below.

207 "[L]e grand manager se balance sur son fauteuil tournant; du haut de sa puissance propre et de la puissance américaine en général il me jette un regard ironique: ainsi la France s'amuse à l'Existentialisme? Bien entendu, il ne sait rien de l'Existentialisme, son mépris vise la philosophie en général et plus généralement encore l'outrecuidance d'un pays économiquement pauvre et qui prétend penser; n'est-ce pas dérisoire de vouloir penser quand on n'a pas l'avantage d'être une des têtes d'un grand journal américain, ce qui d'ailleurs dispense de penser? ... 'Oui, dit-il, en France vous posez des problèmes: mais vous ne les résolvez pas. Nous, nous ne les posons pas: nous les résolvons.' Le fauteuil tourne et craque" $(A J 63)$. Ellipsis in original. 
questions, while on the contrary, in the States, one is a lot closer to professional questions. So the ethics of the profession are very different." ${ }^{208}$

But the New York Intellectuals were right to see that they were a particular target, and they returned the favor, especially with Mary McCarthy's very nasty review, "Mlle. Gulliver en Amérique," which has been picked up in the Beauvoir scholarship, and largely uncritically. ${ }^{209}$

What Mary McCarthy truly hated about L'Amérique aujour le jour 1947 is that Beauvoir did what Americans since Daisy Miller had done to Europe: made the American reader feel like a Lilliputian by reversing the direction of the ethnographic gaze. Like Françoise in L'invitée, McCarthy felt "the look of the Other that steals my world," and made a valiant attempt to seize it back, through character assassination and mockery if not by actual murder. Accompanied by a mystifying ugly caricature of a seated woman who seems to be part robot machine and part ersatz Dogon statue, "Mlle. Gulliver en Amérique" proceeds in McCarthy's characteristic manner not by argument but by mockery and an appeal to what "everyone" knows, without overly concerning itself about what is meant by "everyone."

Peering down at himself, the American discovers that he has "no sense of nuance," that he is always in a good humor, that "in America the individual is nothing," that all Americans think their native town is the most beautiful town in the world, that an office girl cannot go to work

208 A comment that sounds rather chilling, now that we know what de Man did during the Second World War. (And we make excerpts, and assign handbooks, lest our student evaluations complain: “Too Long; Didn't Read.") Stephano Rosso, "An Interview with Paul de Man," 788.

209 McCarthy, "Mlle. Gulliver en Amérique." Elaine Marks reprinted McCarthy's attack in the 1987 Critical Essays on Simone de Beauvoir. See also Penelope Deutscher, Philosophy of Simone de Beauvoir: Ambiguity, Conversion, Resistance, 65-6, and Deirdre Bair, Simone de Beauvoir, 334-35, 386. Deutscher reproduces McCarthy's points without dissent; Bair at times sounds positively gleeful, and seems to have sought out further snide remarks from those she interviewed about Beauvoir's American visit. Her chronology of the visit is unreliable, and she dismisses the political side of L'Amérique au jour le jour 1947 entirely, as something Beauvoir added in afterwards to seduce a French audience, much less interesting than the unfashionableness of what the subject of her biography wore.

McCarthy's was not the only counterattack from the partisans of the mauvais torchon, either: William Barrett, who would become the most influential popularizer of existentialism in America (while explaining that Sartre was actually only a minor moment in its history, and removing all the political bite), had some choice words in his intellectual autobiography, The Truants. Probably the best-known result of this whole sorry map of misprision was Norman Mailer's use of "existentialism" to justify rape and murder in $\mathrm{An}$ American Dream. 
in the same dress two days running, that in hotels "illicit" couples are made to swear that they are married, that it almost never happens here that a professor is also a writer, that the majority of American novelists have never been to college, that the middle class has no hold on the country's economic life and very little influence on its political destiny, that the good American citizen is never sick, that racism and reaction grow more menacing every day, that "the appearance, even, of democracy is vanishing from day to day," and that the country is witnessing "the birth of fascism." 210

Each of these clauses is a malicious twist on a small observation Beauvoir makes, often in the context of a larger narrative of something she witnessed. McCarthy also flattens out the development of Beauvoir's views, ignoring what Robert Bernasconi has described as her "self-correcting method."211

Writing before the English translation appeared, McCarthy dismisses the well-evidenced discussion of segregation and is particularly outraged by Beauvoir's claim that the idea of America as a "classless society" was a "mystification."

She has preserved enough of Marxism to be warned that the spun-sugar façade is a device of "the Pullman class" to mask its exploitation and cruelty: While the soda fountains spout, Truman and Marshall prepare an anti-Communist crusade that brings back memories of the Nazis, and Congress plots the ruin of the trade unions.... ${ }^{212}$

Finally, McCarthy charges Beauvoir with entertaining a paranoid fantasy, "the petrifaction of a fear very common in Europe today - a fear of the future...."213

But McCarthy's defense of America reveals precisely the blind optimism Beauvoir diagnosed. McCarthy even goes so far as to defend the suburbs, which elsewhere in her writing appear as a blight and an abomination. ${ }^{214}$ She writes:

210 McCarthy, "Mlle. Gulliver en Amérique," 34.

211 Robert Bernasconi, "The Smell of Hatred in the Air: Simone de Beauvoir's Account of Anti-Black Racism in the United States."

212 Ibid., 36.

213 Ibid., 37 .

214 Indeed, her real view of the suburbs slips out later in "Mlle. Gulliver en Amérique": "the American problem ... is not one of inequity, as she would prefer to believe, but its opposite. The problem posed by the United States is, as Tocqueville saw, the problem of equality, its consequences, and what price shall be paid for it. How is wealth to be spread without the spread of uniformity? How create a cushion of plenty without stupefaction of the soul and the senses? It is a dilemma that glares from every picture window and whistles through every breezeway" (36-7). 
The society characterized by Mlle. de Beauvoir as "rigid," "frozen," "closed" is in the process of great change. The mansions are torn down and the realestate "development" takes their place: serried rows of ranch-type houses, painted in pastel colors, each with its picture window and its garden, each equipped with deep freeze, oil furnace, and automatic washer, spring up in the wilderness. Class barriers disappear or become porous; the factory worker is an economic aristocrat in comparison to the middle-class clerk; even segregation is diminishing; consumption replaces acquisition as an incentive. The America invoked by Mlle. de Beauvoir as a country of vast inequalities and dramatic contrasts is rapidly ceasing to exist. ${ }^{215}$

Now, the G.I. Bill that built the suburbs was a very good thing (I grew up in one of those little boxes myself), but Black people didn't have access to the G.I. Bill, and those new towns were deliberately segregated. The sharecroppers that Beauvoir saw, she saw. Her description of the censorship trial she attended, of a novel about homosexuality that had been targeted by the Society for the Suppression of Vice, she didn't make up (I checked). ${ }^{216}$ The poll tax and the literacy tests and the systematic intimidation that prevented southern Blacks from voting were real. Fifth Avenue existed (exists) and not everyone can afford to shop there (still can't). The menace of McCarthyism was real; the people Beauvoir met in Hollywood, who spoke to her of the blacklist, were not lying. The atom bomb, too, was not a science fiction fantasy. "Class barriers disappear ...." Well, precisely, and who "disappeared" them? Now, I don't enjoy thinking of myself as a member of "the Pullman class" either, but, well, ça n'empêche pas d'exister. Even Life Magazine knew that Myrdal was right! (But of course the New York Intellectuals looked down on Life Magazine as "midcult.")

L'Amérique au jour le jour 1947 fared better in the Journal of Negro History, where a detailed positive review by the distinguished scholar (and future US

215 The essay ends, "For Europeans of egalitarian sympathies, America is this dilemma, relentlessly marching towards them, a future which 'works,' and which for that very reason they have no wish to face. Hence the desire, so very evident in Mlle. de Beauvoir's impressions and in much journalism of the European Left, not to know what America is really like, to identify it with 'fascism' or 'reaction,' not to admit, in short, that it has realized, to a considerable extent, the economic and social goals of President Franklin D. Roosevelt and of progressive thought in general" (ibid., 37). That McCarthy would pick up and turn around, apparently without irony, Lincoln Steffens's famous (and in retrospect, embarrassing) line about the Soviet Union, "I have seen the future, and it works" shows how fully she-can I be about to say "brainwashed"?

216 The book in question was Calder Willingham's End as a Man, based on his experiences at the Citadel. 
ambassador) Mercer Cook concludes: "it is less ephemeral than its title would suggest. Few contemporary studies offer Americans a better opportunity to see ourselves as others see us." ${ }^{217}$ (He did feel that Beauvoir had understated the opposition to segregation among college students.)

All this is especially disappointing because Beauvoir and McCarthy had so much in common. To the generation of women who came of age in the 1950s and 196os, both stood for the rare combination of intellectual prowess and sexual freedom. Each had flourished personally and professionally as the only woman in a very male and fairly aggressive intellectual atmosphere; scholars of women's autobiography have often discussed them together, because they describe shuffling off the shackles of Catholic upbringing in very similar ways; both were seemingly fearless truth-tellers, including when they wrote about heterosexuality from the woman's point of view.

And yet the antipathy between them seems to have been immediate, visceral, and lasting, as Eugenia Zimmerman details (drawing on Carol Brightman's biography). ${ }^{218}$ Beauvoir refers to McCarthy as "that beautifully cold novelist who has already gone through three husbands and several lovers in the course of a cleverly laid out career,"219 and McCarthy, as Zimmerman says, "returned the compliment ... nearly thirty years after the 'Prettiest Existentialist' first visited New York. In 1980, six years before Beauvoir's death, McCarthy expressed herself thus: 'How dare she talk about injustice to women, and how as a woman she's been deprived when she has put herself on the map solely by attaching herself to Sartre, solely. Sartre et moi. He made her ... She's not utterly stupid ... she would be a good " $\mathrm{B}$ " student somewhere in the intellectual world...." 220

217 Mercer Cook, "Review of America Day By Day." Mercer Cook (1903-87), future US ambassador to Senegal and the Gambia, Professor of French and English, translator of Senghor, head of Romance Languages at Howard, received his teaching diploma from the Sorbonne in 1926. Cook also notes omissions from the translation, and takes mild issue with Wright's statement (quoted by Beauvoir) that Blacks are conscious of racism "every single moment." The same issue of The Journal of Negro History contains a positive review of Richard Wright's The Outsider.

218 See Eugenia Zimmerman, "Simone de Beauvoir, Mary McCarthy and The 'Woman' Intellectual," Carol Brightman, Writing Dangerously: Mary McCarthy and Her World, and Francis Kiernan, Seeing Mary Plain: A Life of Mary McCarthy. In an interesting article, Tina Chanter has discussed McCarthy's violent hatred of Beauvoir under the rubric of "abjection," which she sees as generally characteristic of later feminist responses to Beauvoir ("Abjection and Ambiguity: Simone de Beauvoir's Legacy").

219 Brightman, Writing Dangerously, 346.

220 Ibid., 342; Brightman's italics. McCarthy didn't like Sartre any better, though, and Zimmerman quotes John Gerassi to the effect that Sartre "carefully avoided [McCarthy] because, he said, she was an 'arrogant imperialist witch." Zimmerman comments further: "Mary McCarthy was part of the cultural furniture of a New York adolescence in the 1950s. 
Writing to Sartre after she met McCarthy, Beauvoir called McCarthy "typique," and of course no one likes to be "typical."221

Brightman's diagnosis that "McCarthy's 'deep ambivalence' for the 'new America' is project[ed] onto Simone de Beauvoir" is an apt one: McCarthy's review of Beauvoir tells us more about her own confusions than about Beauvoir's book. ${ }^{222}$ Like Macdonald and others of the group, she held an inconsistentnot to say incoherent-view of American mass culture. They liked to think of New York as a branch of Europe; visits from actual Europeans showed them they weren't as different as they believed from the Babbitts they mocked. To expose the complicity of New York Intellectuals with American cold warriors was to challenge their sense of themselves as cosmopolitan: if Beauvoir was right, McCarthy's whole stance in the world, the story she has been telling herself, was a lie.

The thing is, I like Mary McCarthy. She was whip-smart, and a very good writer, and nothing about that extraordinarily aggressive group cowed her. ${ }^{223}$ Stories from The Company She Keeps (1942) broke open a whole host of taboos about sex; when The Group appeared in 1963 (the same year as The Feminine Mystique) it was, I've argued elsewhere, a contribution to the feminist arguments McCarthy herself wasn't quite willing to make. ${ }^{224}$ Like Doris Lessing, McCarthy laid out all the data, but balked at drawing the conclusion. ${ }^{225}$

McCarthy was a good friend to Hannah Arendt when Arendt needed one, and she was, herself, intellectually up to the job of translating Simone Weil's "The Iliad, or the Poem of Force" and editing Arendt's The Life of the Mind for posthumous publication. She was famous for her wicked tongue- " $[\mathrm{t}]$ orn animals were removed at sunrise from that smile," as an Esquire profile had it—and

Simone de Beauvoir offered-or appeared to offer-that same generation of bookish young women the image of a life in which conventional and iconoclastic choices could be integrated and reconciled: love and work, the emotional and the intellectual, a man and a career" (Zimmerman, "The 'Woman' Intellectual," 113).

221 Beauvoir, Lettres à Sartre, 301.

222 Brightman, Writing Dangerously, 338.

223 Delmore Schwartz, for instance, used to refer to her writings as "Tidings from the Whore." From Elizabeth Hardwick's introduction to McCarthy's Intellectual Memoirs (128): "An evening at the Rahvs' was to enter a ring of bullies, each one bullying the other." A line from one of Robert Lowell's poems- “How we wish we were friends with half our friends!" nails the overlay of personal and literary politics rather well ("Ulysses," in Selected Poems, 225).

224 See Altman, "Beyond Trashiness."

225 What Beauvoir noticed at Vassar-drawing McCarthy's ire-is quite close to what McCarthy would later satirize about her alma mater in The Group. (Perhaps Vassar really was like that. See also Muriel Rukeyser, "More of a Corpse Than a Woman.") 
many of the people she bit royally deserved it. She was no friend to feminists, as Zimmerman explains: "McCarthy not only denounced Beauvoir per se, she also denounced feminism for its 'self-pity, shrillness and greed'; 'feminism is bad for women ... [I]t induces a very bad emotional state."'226 Neither, for that matter, was Arendt, who is known to have remarked that "Women's Liberation just does not say hello to me at all," and later, "What will we lose if we win?"227

McCarthy tends to disavow her own early radicalism as the skittishness of a boy-crazy misfit, presenting herself retrospectively as a kind of accidental Trotskyite. "It was not difficult, after all, to be the prettiest girl at a party for the sharecroppers." 228 At the time she met Beauvoir, the splinter group formed with Dwight Macdonald, Nicola Chiaramonte, and a few others were attempting more or less what Les Temps Modernes stood for, to be a non-Communist voice on the left. But if there wasn't much space for that in Paris, there was even less in the United States. Anna Bogic tells us:

In the Nation, Patrick Mullahy wrote that The Second Sex "is in many ways a superb book, brilliantly written with a broad scope and keen psychological insight"; however he warned that "because of certain political leanings Mme. de Beauvoir has to be read with critical caution."229

226 Brightman, Writing Dangerously, xviii, 343.

227 Elizabeth Young-Bruehl, Hannah Arendt: For Love of the World, 513. Bair (332) reports Arendt as having told William Phillips (according to the latter) that he would have gotten on better with Beauvoir if he had flirted with her, as opposed to attempting a discussion. But a turning point, as marked in the McCarthy/Arendt correspondence, occurs when Robert Lowell leaves Elizabeth Hardwick, who had stuck with him for many decades despite his serious manic-depressive episodes, and ... other difficulties. McCarthy wrote, "I feel very sorry for Cal and troubled about him, and yet this final piece of arrogance makes me almost angry. Women's lib" (Carol Brightman, Between Friends: The Correspondence of Hannah Arendt and Mary McCarthy, 273).

Lori Marso calls Arendt and Beauvoir "unrecognized allies" (41) in a highly illuminating comparison of Beauvoir's 1946 account of Robert Brasillach's treason trial, "Oeil pour œil” (An Eye for an Eye) to Arendt's Eichmann in Jerusalem (Politics with Beauvoir, 41-65). On the level of political theory, she is convincing; but the reasons why the two didn't "recognize" one another as "on the same side," either personally or politically, still seem important.

228 Mary McCarthy, The Company She Keeps, 112. See also Hardwick's introduction to McCarthy's Intellectual Memoirs, 66. There is something so arch, so knowing about McCarthy's tone, so much the opposite of the "earnestness" of the angry young man- "he's fair and he's true and he's boring as hell," in the words of Billy Joel. (And he is all those things.) And yet when an arch and knowing skeptic is actually roused to anger, as McCarthy was by Vietnam and Watergate, it's a powerful weapon.

Bogic, “Uncovering Hidden Actors: The 'Making' of The Second Sex," 175. 
Another prominent New York Intellectual was Elizabeth Hardwick, whose very strange review of The Second Sex in the Partisan Review could stand in for the initial American response. ${ }^{230}$ This reviewer hid her awareness that Beauvoir's book was, in the main, astute, in so much mockery and scolding that her piece reads like a bitter attack. Here's how it starts:

Vassal, slave, inferior, other, thing, victim, dependent, parasite, prisoneroh, bitter, raped, child-swollen flesh doomed to immanence! Sisyphean goddess of the dust-pile! Demeter, Xantippe, Ninon de Lenclos, Marie Bashkirtsev, and "a friend of mine...." Cave to café, boudoir to microscope, from the knitting needles to the short story, this potency of pages, this foreshortened and exaggerated mysterious and too clear relief, this eloquent lament and governessy warning, this poem and doctoral thesis-I suppose there is bound to be a little laughter in the wings at the mere thought of this madly sensible and brilliantly confused tome on women by Simone de Beauvoir, The Second Sex..$^{231}$

Hardwick's review mainly chronicles her own bewilderment and defensiveness: that same arch and knowing New York Intellectual tone is in full cry, but I find her overall argument as difficult to parse as she found The Second Sex. ${ }^{232}$ Much later, after she'd produced a feminist novel and Seduction and Betrayal (1974), one of the first significant books of feminist criticism to appear in the United States, Hardwick was asked, "would you still stand on that?" and replied, “no. No, I wouldn't. It's a wonderful, remarkable book. Nothing that has come since on the matter of women compares to it."233 Such a décalage between first and later reading is a pretty common experience-it was, in fact, mine. But Hardwick's original piece from the 1950s, like McCarthy's, continues to be anthologized and cited.

The question I have is, why did Hardwick find this book opaque and confused, when Lorraine Hansberry found it brilliantly clear and comprehensive?

Hansberry herself is unsparing in explaining why there had not been more uptake of the book: she refers to the "American myth of the already liberated woman of all classes," and gives short shrift to those who provide gossip about

230 For a fuller discussion, see Judith Coffin, "Historicizing The Second Sex," and Jo-Ann Pilardi, "The Changing Critical Fortunes of The Second Sex."

231 Elizabeth Hardwick, "The Subjection of Women," 321.

232 "I take up the bewildering inclusiveness of this book, because there is hardly a thing I would want to say contrary to her thesis that Simone de Beauvoir has not said herself" (ibid., 322).

233 Elizabeth Hardwick, "The Art of Fiction No. 87." 
the writer instead of analysis. ${ }^{234}$ "Women who can't read such a long work reflect their historical experience of utter intellectual impoverishment as a class ..."; they can't understand it "any more than I should imagine a slave prior to the civil war could have understood intellectually the nature of his bondage.... The overwhelming majority of American women (like the overwhelming majority of American men) do not read books." ${ }^{235}$ This is true even of intellectuals: "We are a people, as oft noted elsewhere, who have grown accustomed to thought reduced on the tabloid sheet to far below its least common denominator."236 She does, however, praise the women of the left. "That so much of the fight against 'male supremacy' in the American communist movement can be so negatively described is not the fault of the women."237

But Hansberry's understanding that The Second Sex was a political book was rare. As Rosie Germain has shown, ${ }^{238}$ The Second Sex was received in the United States primarily as a work of social science-indeed as a work of "sexology"239 Partly this was because Blanche Knopf had it marketed that way (as she wrote to Parshley, existentialism was a "dead duck" from a commercial point of view). ${ }^{240}$ But also, by 1953, when The Second Sex was discussed in Time magazine and other widely read outlets, "women's 'fulfilment' was already, and would continue to be, a popular topic of debate."241 But "fulfillment" and its antithesis, frustration, were being discussed in a way that entirely left out "feminism," which Germain sees to have been a truly dead duck. ${ }^{242}$

234 Hansberry, "Simone de Beauvoir and The Second Sex: An American Commentary," 129, 128.

235 Ibid., 129, 132.

236 Ibid., 133 .

237 Ibid., 132.

238 Rosie Germain, "Reading The Second Sex in the 1950s."

239 Ibid., 1048-1052.

240 Ibid., 1044. See also Anna Bogic, "Why Philosophy Went Missing: Understanding the English Version of The Second Sex," 160.

241 Germain, 1045. As Germain shows, "[t]he reception of The Second Sex ... fits awkwardly into the historiography of the 5os. Much of this historiography has focused on the question of whether this should be seen as a culturally 'conservative' or 'progressive' decade" (1046). Perhaps my analysis can contribute to an understanding that that is, in fact, the wrong question. For a debunking of the idea of supposedly dead time "between the waves," see also Joanne Meyerowitz, Not June Cleaver: Women and Gender in Postwar America, 1945-196o, Elaine Tyler May, Homeward Bound:American Families in the Cold War Era, and Wini Breines, Young, White and Miserable: Growing Up Female in the Fifties.

242 Germain notes that while British readers read exactly the same book (Parshley's translation), there was no comparable popular interest in social science, no vogue for sexologymost British public intellectuals were economists, who did not review the book, and British publisher Jonathan Cape "had, in striking contrast to Knopf, actually requested that 
It was this term, "fulfillment," that would carry over so powerfully into The Feminine Mystique, written by a woman who had trained as a psychologist during the heyday of functionalist social science. Friedan built a feminism within the comfort zone of middle-class femininity, much as Elizabeth Cady Stanton had done a century earlier. The differences between Beauvoir and Friedan were well-cataloged as early as 1980 by Sandra Dijkstra, who described Friedan as "a translator who could boil down its ideas, and its theory, into less radical, more readable journalese," making both problems and solutions more individualistic, thus more palatable. ${ }^{243}$ Friedan did not admit Beauvoir's influence on her work until 1975, and then rather grudgingly; a meeting between them was a dialogue of the deaf, since Beauvoir wanted to abolish the family and Friedan wanted to save it, through basically reformist solutions that involved thinking about things differently. In Dijkstra's words, Friedan "eliminated the radical core"; Beauvoir's response was that she intended "to sap this regime, rather than play its game."244

Friedan describes her trip to Paris as a pilgrimage to consult a movement "Goddess," seeking advice because the American movement had lost its way. (Some of this is quite bizarre, to be honest.) "In the last two years in America," she tells Beauvoir,

some of de Beauvoir's references to sexual intimacy be cut" ("Reading The Second Sex in the 1950s," 1061). It was reviewed mainly by literary writers and was received as a feminist text, for instance in the suffrage journal Time and Tide, which was still publishing.

Germain also shows that, while "The Second Sex was ... to some extent, a transatlantic work from inception, particularly so when seen in the context of social science," American reviewers, proudly invested in American ideal of "modernity," were quick to attribute the parts of The Second Sex they didn't like to national differences (1043). She quotes among others psychiatrist Clara Thompson: "If [Beauvoir's] picture is true of present day France, then France is about fifty years behind us" (1054). Beauvoir's portrait of American women as smugly certain that they are already emancipated seems to be borne out. (The label of "modernity" was also a pretty good way to sell kitchen appliances.) Ironically, Judith Coffin ("Historicizing The Second Sex") found that the negative reviews in France tended to complain that The Second Sex was too American!

243 Sandra Dijkstra, "Simone de Beauvoir and Betty Friedan: The Politics of Omission." See Betty Friedan, "Sex, Society and The Female Dilemma."

244 Dijkstra, "The Politics of Omission," 298. In Tout compte fait, Beauvoir would call The Feminine Mystique an "excellente livre" (an excellent book), but would deplore the lack of radicalism in the National Organization of Women, calling it "soon irrelevant" (bientôt dépassé) (618). She describes the American feminist scene with an accuracy that shows her to be well informed, and details her points of agreement and disagreement with various groups and writers. 
there has been a diffusion of energy in an internal ideological dispute. Women began to realize their potential power with the passage of the Equal Rights Amendment right before the ' 72 elections and the Supreme Court's decision on abortion. At that point, forces on the far right began a well-financed campaign to prevent ratification of ERA in the States and to overturn the abortion decision. From testimony at the Watergate hearings, we suspect that agents provocateurs were also at work within the Women's Movement, fomenting disruption and extremism, fanning the divisive note of sexual politics-"down with men, childbearing and motherhood!" The attempt to make a political ideology out of sexual preferences, out of lesbianism, has diverted energies from the political mainstream and hindered the political momentum of the Women's Movement. 245

Beauvoir replied, "well, of that, I'm not sure," and things went rapidly downhill from there. Friedan asked about work, Beauvoir answered that the women in the Lipp factory ... but that wasn't what Friedan meant by work. Beauvoir refused to endorse the idea of "wages for housework," and so on. In the end, the pilgrim, disappointed at not getting the answers she wanted, turned on the goddess as cold, overly dependent on Sartre, etc: "And then I recognized the authoritarian overtones of that supposedly Maoist party line I've heard before from sophomoric, self-styled radical feminists in America...."246

Since Dijkstra wrote, it has been asserted that Betty Friedan under-reported the radical leftist background of her own thinking and practice. Daniel Horowitz's book, Betty Friedan and the Making of The Feminine Mystique, ${ }^{247}$ is unsatisfactory in a number of ways: I'm not sure he can be exonerated from the charge of red-baiting, though that may not have been his intention. However, if, as his archival work does appear to show, Friedan deliberately minimized class analysis, and sanitized her own history by failing to mention her communist-related activities, in order to reach a broader audience of women, she would hardly have been the only one. ${ }^{248}$ This actually strengthens my view of the importance of Cold War contexts in the separate development of American and European feminisms - and provides evidence of their persistence. Whatever Friedan's intention or reasoning was, it seems obvious that if The Feminine Mystique had been more "radical" it would not have reached the

245 Friedan, "Sex, Society and the Female Dilemma," 14.

246 Betty Friedan, "No Gods, No Goddesses," 17.

247 Daniel Horowitz, Betty Friedan and The Making of The Feminine Mystique.

248 See Weigand, Red Feminism. 
broad audience it did. And again, this is a self-fulfilling and self-perpetuating prophecy: but that doesn't make it an inaccurate one.

Certainly Beauvoir's contribution to feminist theory does not reduce to an intervention in Cold War politics. But I am arguing that the reception of her work can't be well understood apart from that frame, which (to put it schematically) acted on The Second Sex like a screen, or a strainer, to the point that when Spelman looked into the bowl there was nothing to see.

However, when American readers (hostile, friendly, or passive-aggressive) understood The Second Sex as a work of psychology, they were not wrong, exactly.

In one of the infrequent passages in Les mandarins where Anne refers to the book she is working on, she describes it as an attempt to reconcile Marx and Freud. It would be over-reaching to say that the book Anne is quietly writing turns out to be The Second Sex; for one thing, Anne is not primarily interested in understanding women. A practicing psychoanalyst who works with Holocaust survivors, many of them children, she is looking for a way to help heal trauma that would not require repudiating the real horrors of the war, a way to honor the victims of war without sacrificing one's own future to survivor guilt. This will require working politically toward a better world; a "private solution" will not be enough, indeed the real pain of these others demands more than a "private solution." To "cure" is, as she sees it, a mutilation; yet to understand the intimate injuries that result from collective injustices, to look for "techniques" to heal them, strikes her as an honorable task. ${ }^{249}$ We do not hear much more about Anne's book: indeed, when Scriassine asks her whether she writes, her response is to laugh and say, "God, no!"250 But those two projects-work on the self, work on the world-in tension yet indissoluble, like the "I" and the "we," animate Beauvoir's political thinking, from the Liberation onwards. This was something important she had in common with Richard Wright. It was also something they both had in common with Frantz Fanon. All three shared the view that oppression creates psychologically and morally defective

249 See Les mandarins 1:73, 91-3. As Beauvoir says in her memoirs, it is a mistake to take Anne as a stand-in for the author; she put as much or more of herself into Henri. "He resembles me at least as much as Anne does, and perhaps more." [Il me ressemble autant qu'Anne au moins, et peut-être davantage ( $F C h$ 1:367).] But it is also too simple to accept the separation Beauvoir makes in those retrospective pages between Henri-the-writer-and activist and Anne-the-"être relatif."

250 "Ils écrivent tous, n'est-ce pas?

-Tous.

—Vous, vous n'écrivez pas?

Je dis en riant: 'Grand Dieu non!'” (Les mandarins, 1:49). 
forms of subjectivity, which are artifacts of situation rather than intrinsic defects (though the results may look the same); oppression must thus be fought simultaneously on several fronts, and with a complex, sometimes contradictory, set of instruments. ${ }^{251}$

\section{Reading Beauvoir with Fanon}

One quick way of saying what The Second Sex "is about" is that it attempts to demystify and liquidate the notions of femininity that cause women to be treated as "Other" by culture, by men, and by themselves. That urgent task of demystification is a major parallel with Frantz Fanon's first book, Peau noire masques blancs, which appeared only three years later, and which is a powerful analysis of the psychological and cultural effects of racism. I first began thinking about this when I noticed that Fanon has a chapter called, "Lexpérience vécue du noir" (The Lived Experience of the Black), which recalls the title of volume 2 of The Second Sex. ${ }^{252}$ That's a small point in itself, but there are many other signs that the project of inquiry was similar. In the words of Toril Moi (probably the first to have commented on the resemblance), "where Beauvoir... construct[s] a highly complex theory of female alienation under patriarchy, Fanon mobilizes the same thinkers to theorize Black alienation in a racist society."253 Both Beauvoir and Fanon offer strongly Hegelian accounts of the subject's struggle for recognition in the face of a hostile, "othering" gaze. Both make serious use of psychoanalysis while remaining alert to the biases that can

251 Again, see now Lori Marso, Politics with Beauvoir (94, 97-121) for an extended comparison with Fanon. Marso engages (as I do not) with affect theory and with political theories of violence, and she concentrates most fully on Les damnés de la terre where I have emphasized Peau noire masques blancs, but I am substantially in agreement with her conclusions.

252 The origin of the French phrase is with Merleau-Ponty. It was unhelpfully translated by Charles Lam Markmann as "The Fact of Blackness," in a parallel to Parshley's mistranslations, and with parallel unhelpful effects on Anglophone Fanon scholarship. In both cases, what is lost is not simply the indebtedness to Merleau-Ponty but the intentionally subjective nature of the accounts given: this is the lived reality of an embodied consciousness, told from the inside out. David Macey also criticizes the way in which the American translation of Peau noire masques blancs in 1967 dislocates Fanon from a Francophone context and, through mistranslation, transforms him into the archetypal Negro from the American deep South (Macey, "Adieu Foulard, Adieu Madras," 17). And Nigel Gibson points out that Markmann obliterated the distinction Fanon makes between "Noir" and "nègre" (Rethinking Fanon: The Continuing Dialogue). The English versions in my book are based on Markmann's, but I have altered them, in some cases significantly, so the responsibility for any errors should properly be mine.

253 Moi, Making of an Intellectual Woman, 204. 
infect it, to the way it can work as a tool of social coercion; both books are centrally concerned with sexuality as a social and cultural force, and both have some forthright and uncomfortable things to say about the bourgeois European fantasy-world. Both draw examples and arguments indiscriminately from a range of disciplines and discourses, importantly including literary texts as well as personal narrative, though in Beauvoir's case the "I" is more often veiled. ${ }^{254}$ Both deploy a range of methodological tools and rhetorical strategies, which they are nonetheless willing to criticize. Max Silverman writes about Fanon that "[d]iscourses of liberation such as psychoanalysis, the Hegelian dialectic and phenomenology are adopted as useful tools for prising open the nature and extent of white oppression but are also exposed as false universalisms when confronted by the specificities of 'the lived experience of the black man." 255 If we substitute "women" for "the black man," that sentence fits Beauvoir. Fanon presents himself as a psychoanalyst - sort of - and Beauvoir presents herself as a philosopher-sort of - but both in fact draw on all sorts of evidence for their positions, and are no respecters of disciplinary purity. ${ }^{256}$

Rather obviously, both Beauvoir and Fanon had serious intellectual engagements with Sartrean existentialism, and both importantly dissented from and struggled with aspects of his thinking, though Fanon marked his struggle with Sartre explicitly in his text and Beauvoir chose not to. Each also helped move Sartre himself past some impasses at key points in his intellectual and political development. Both also had important intellectual engagements with the phenomenology of Merleau-Ponty, whose lectures Fanon attended in Lyon while studying for his medical degree. ${ }^{257}$

Both Fanon and Beauvoir are extremely critical of members of the oppressed group they belong to whom they see as complicit with their oppression—-both

254 Both Beauvoir and Fanon were partly writing to understand who they were by understanding their place in the world, but neither makes this explicit: both essays open (as indeed did Woolf's A Room of One's Own) by stating that the writer is not angry, that the time for anger is past. In all three cases this opening move to conciliate or reassure the reader is revealed to be a lie, but not in a manipulative fashion: it is as if the writer discovered her or his own anger through the process of writing the book.

255 Max Silverman, "Introduction," in Frantz Fanon's Black Skin, White Masks: New Interdisciplinary Essays, 3 .

256 See David Macey, "The Recall of the Real: Frantz Fanon and Psychoanalysis." Lewis Gordon notes that it is "not written in a way that one could readily identify what kind of work it is," and cites Jane Anna Gordon, who calls this way of writing "creolized" (Lewis Gordon, What Fanon Said: A Philosophical Introduction to His Life and Thought, 73). Gordon sees "methodological fetishism and disciplinary decadence" as having impeded a clear understanding of Fanon's work (ibid., 74).

257 Ibid., 13. 
texts foreground criticism of complicity and of inadequate self-justification, including through sarcasm and mockery. And both call, in very explicit terms, for the subjects of history to reinvent themselves, as Beauvoir's "independent woman" - "the free woman is just being born"—or the fully decolonized "new man" of whom Fanon says, "il faut faire peau neuve." ${ }^{58}$ This may be why both were and continue to be inspiring, energizing books for all sorts of readers, even though the picture they paint is a bleak one, and even though neither is what you'd call an easy read.

Writing in 1994, Moi rightly noted that the influence of Beauvoir on Fanon had been underacknowledged — beginning, it must be said, by Fanon himself.

Fanon himself makes absolutely no reference to The Second Sex. Nor does he seem even remotely interested in the question of women's liberation. Writing his essay as a medical student in Lyons, Fanon was influenced by existentialism, and-judging by his footnotes-clearly an assiduous reader of Les Temps Modernes. In 1948 and 1949 the existentialist journal published many excerpts from The Second Sex, yet Fanon fails to mention any of them. Nor does he refer to the full-length book, although he could hardly have been unaware of its publication and the outraged response it provoked in France in 1949 and 1950. Unfortunately, Fanon's explicit invocation of Sartre and his total neglect of Beauvoir exemplify the usual response of male intellectuals to existentialism [and] ... it would seem that present-day colonial and post-colonial critics have done nothing to change this unhappy state of affairs. ${ }^{259}$

Fortunately, the last point is no longer true. Among others, Lewis Gordon's 2015 book What Fanon Said forthrightly explores Beauvoir's "presence at the level of ideas but exclusion at that of citation" which he calls "a form of epistemic sexism" and finds he "cannot excuse." ${ }^{260}$ Gordon begins by noting

258 Literally, "make a new skin," usually translated by "turn over a new leaf" (Fanon, Les damnés de la terre, 305).

259 Moi, Making of an Intellectual Woman, 204.

26o Gordon, What Fanon Said, 32. Perhaps another parallel is that despite all the books on Fanon already in existence, a book with that title was still badly needed. Gordon's first chapter is devoted to the ways Fanon has been reduced to his biography, or read as a tissue of influences, which flow in one direction: why is Fanon seen as Sartrean when Sartre is not seen as Senghorian or Wrightian? And Gordon's discussion of how Peau noire masques blancs has been read through various disciplinary agendas leads him to an impatience much like my own about The Second Sex: could people please just read the book? See also Henry Louis Gates: "Frantz Fanon, not to put too fine a point on it, is a Rorschach blot with legs" (“Critical Fanonism," 252). 
the insight, which Fanon erroneously attributes to Nietzsche, that (in Fanon's paraphrasing) "Man's misery (le Malheur) is that he was once a child."261 The actual source was Simone de Beauvoir's The Ethics of Ambiguity (1947), a text that, along with The Second Sex (1949), as Matthieu Renault informs us, reveals affinities between Beauvoir and Fanon ... Although at first an observation on the human condition, Beauvoir subsequently brought it to bear on specific modes of embodiment, identities, and the longing human beings may have for times before such ways of being were realized. Her observation in The Second Sex of not being born but instead becoming a woman is premised on this insight and clearly prefigures Fanon's thesis of the black as a white construction, that blacks are made or constructed. As Beauvoir scholarship reveals Jean-Paul Sartre's indebtedness to her for crucial concepts such as the Look and discussions of concrete relations with others in Being and Nothingness, it is clear that Fanon, too, is influenced by her thought on at least the philosophical anthropology of human development, the limitations of Hegelian dialectics of recognition, and the importance of psychoanalysis in his inaugural work. ${ }^{262}$

Amey Victoria Adkins has argued similarly that "a close reading of Fanon's groundbreaking analysis in Black Skin, White Masks reveals a pattern of analysis uncannily similar to Beauvoir's The Second Sex."263 She takes Fanon to task for his "erasure" and "silencing" of his debt to Beauvoir, connecting this to his "use of the universal masculine" and negative portrayals of women. ${ }^{264} \mathrm{Her}$ comparison starts from an eloquent reading of Fanon's famous confrontation with the white child: "Look! A Negro!"- "the shattering shared experience of blackness and black being in a white world" which catalyses a "crucial, crucifying perspectival shift.” She compares this to Beauvoir's equally harrowing

But of course we are all reading the same books, really. Maybe the distinction I've been trying to draw is between a clever reading, which seizes on some arcane and little-noticed aspect of a familiar text as an occasion for display of the critic's own brilliance, political acumen, or whatever, versus a sound reading, which foregrounds an attempt to account for the thought of the textual other in a full and responsible way.

$261 \quad$ РNмB 8. Beauvoir herself attributes the idea, not to Nietzsche, but to Descartes.

262 Gordon, What Fanon Said, 31. The article Gordon references (Matthieu Renault, "Le genre de la race: Fanon lecteur de Beauvoir") is truly excellent: only my determination to keep issues about "readings of Hegel" from taking over my project prevents me from engaging with it further here. Renault confirms that Fanon owned (at least) the first volume of The Second Sex, and annotated it.

263 Amey Victoria Adkins, "Black/Feminist Futures: Reading Beauvoir in Black Skin, White Masks," 698.

264 Ibid., 698, 700 . 
analysis of what it is to be "taken to be a woman," interpellated at birth (now, even before birth) by the announcement, "it's a girl!" and indoctrinated, from one's earliest moments, into the shame of being "seen" that results in a similarly crippling self-alienation. ${ }^{265}$

To bring these two insights together is a powerful move. But what stays with me is not so much the question of who the insight originates with, or belongs to, as the power of the insight itself. The texts resonate and live because their description of this moment of being "Other" describes an experience that very many women, and very many people of color, have actually had - and that is a truth about the world we live in that no writer, no person, "owns." Here's an understated version, called "Incident," published in 1925, from Harlem Renaissance poet Countee Cullen:

Once riding in old Baltimore,

Heart-filled, head-filled with glee,

I saw a Baltimorean

Keep looking straight at me.

Now I was eight and very small,

And he was no whit bigger,

And so I smiled, but he poked out

His tongue, and called me, 'Nigger.'

I saw the whole of Baltimore

From May until December;

Of all the things that happened there

That's all that I remember.

265 The example Adkins gives in illustration comes from Beauvoir's "Formation" section; as she observes, it is one among (very) many. "A man, sniggering, made a comment about my fat calves. The next day, my mother made me wear stockings and lengthen my skirt, but I will never forget the shock I suddenly felt in seeing myself seen.' The little girl feels that her body is escaping her, that it is no longer the clear expression of her individuality; it becomes foreign to her; and at the same moment, she is grasped by others as a thing: on the street, eyes follow her, her body is subject to comments; she would like to become invisible; she is afraid of becoming flesh and afraid to show her flesh." ["Un homme a fait en ricanant une réflexion sur mes gros mollets. Le lendemain, maman m’a fait porter des bas et allonger ma jupe: mais je n'oublierai jamais le choc ressenti soudain à me voir vue." La fillette sent que son corps lui échappe, il n'est plus la claire expression de son individualité; il lui devient étranger; et, au même moment, elle est saisie par autrui comme une chose: dans la rue, on la suit des yeux, on commente son anatomie; elle voudrait se rendre invisible; elle a peur de devenir chair et peur de montrer sa chair ( $D S$ 2:65, quoted in Adkins, "Black/Feminist Futures," 703-4).] 
Examples (for people of color, and for women of all races) might be multiplied almost indefinitely, drop by drop, until they become a seething sea of pain and outrage. ${ }^{266}$ Some such encounters are immediately deadly (see also under, Baltimore), some are damaging in more insidious ways.... Did Fanon read Countee Cullen? He could have. Did Countee Cullen read Hegel? In a way, who cares?267 The next time I am in my office with a first-year student to whom that exact thing has happened that very day, shall I act like Mariah in the Jamaica Kincaid story and say to her, "oh, here's a book that analyses what just happened to you"? (And which book shall I offer?) And will I be surprised if the student looks at the book, and looks back at me as though I am, literally, crazy?

Sorry. The politics of citation is important, and not just for those with careers to make: writers who are not given credit for their ideas fall out of view, and their thinking is lost to us; intellectual history then seems whiter and maler than it actually was, which can be unnecessarily daunting to those not white and male who seek to enter it; and then there's the question of scholarly ethics. ${ }^{268}$ But if the task is actually to engage with the world, and not just texts, we need to keep before our eyes that the politics of citation is not the only politics that there is. When I ask myself why scholars (including myself) have been more concerned with protecting Beauvoir's intellectual property rights than she ever was herself, I remember that an over-obsessiveness about whether people cite one's own work is the mark of the Serious Man (and we've all met him, if only as "reviewer number two"). Perhaps Beauvoir thought of her intellectual and political work less as a product, and more as a project, which would mean an endeavor that is valuable only insofar as it is shared. ${ }^{269}$ That could be a good idea to try.

266 See Coates, Between the World and Me; see Baldwin, No Name in the Street; see ... the newspaper ...

267 He easily could have: he went to Harvard ... his father-in-law was a prominent American Hegelian named W. E. B. DuBois... But he certainly hadn't read Hegel before the age of eight.

268 Nobody's footnotes are perfect, though. Adkins's discussion of Richard Wright doesn't credit Margaret Simons' work, and her citation of Buck-Morss's Hegel and Haiti is misleading: that book, wonderful as it is, does not mention Beauvoir on page 20, or anywhere else. And I'm sure I have not eliminated all such errors from this book, either.

Maybe there's a bigger picture, though. I suggested in chapter 1 that the most powerful influences on Beauvoir's thought were the ones she cites least: perhaps that is also true of influences on Fanon? Perhaps it is true more generally? Suleiman ("Breton ou la poésie") makes a similar point about Beauvoir's influence on feminist literary criticism, including her own.

269 Beauvoir's history with Les Temps Modernes makes clear that she cared less about getting her name on the masthead than about making sure the work of speaking truth to power actually got done. One could contrast this with what she had to say about the Partisan 
Gordon's discussion of Fanon's relationship to Beauvoir makes a lot of sense to me. While noting that the catalogue of Fanon's library shows he owned two of Beauvoir's books, ${ }^{270}$ Gordon also underlines the importance of Richard Wright to both Beauvoir and Sartre, and the importance of Wright and Sartre to both Beauvoir and Fanon.

This circle of thought reveals an evolving community of ideas in which each influences the other, through which to draw on the resources of one is to evoke the other. There is, in other words, a fundamental relationality of ideas through which speaking of race in terms of gender reveals a symbiosis of each. Acknowledging Beauvoir means, in other words, also evoking Wright, and reading through Fanon should, then, bring forth Beauvoir and the many exemplars of existential critical work on oppression. ${ }^{271}$

Whether a certain idea passed from Wright to Beauvoir to Fanon, or from Wright to Fanon directly, and what role was played in all of that by Sartre's ideas about Jews, matters less than the ideas themselves. ${ }^{272}$ And worrying about who "invented" the social construction of the oppressed consciousness seems liable to distract us from the force of that insight in all their work: we are free to change. Why haven't we? Are we going to? How? If not now, when?

Why I started down this road is that reading Fanon and Beauvoir together brought some things about each of them into clearer view. ${ }^{273}$ One has to do with the history and uses of psychoanalysis: like Beauvoir, Fanon brings to bear

Review group's approach to their mauvais torchon. There's also the rule of thumb that one can get a great deal done provided one does not care about getting credit for it.

270 Gordon doesn't say which two: Fanon's reference ( $P N M B$ 148, BSWM 141) to Beauvoir walking with Wright in New York City (and being harassed by a white passerby) tells us he read L'Amérique au jour le jour 1947, at least, though he gives no footnote. Large sections of that book, and of The Second Sex, were serialized in Les Temps Modernes.

271 Gordon, What Fanon Said, 33.

272 An exemplary reading along these lines is Annabelle Golay, "Féminisme et postcolonialisme: Beauvoir, Fanon, et la guerre d'Algérie." Golay situates the face-to-face encounter between the two in Rome in 1961, as recounted by Beauvoir in La force des choses, in the light of carefully contextualized readings of Fanon's late texts about the veil and Beauvoir's writing about the case of Djamila Boupacha. I'll engage with this further in chapter 5 .

273 And I suppose I also hoped to show that if the methods and insights that were useful to her were also useful to such a person as Fanon, she cannot be as bankrupt from the point of view of race and class analysis as some commentators believe. I can spot the excluded middle in that reasoning, really. But it is curious that the routine denunciation of Beauvoir as "Hegelian" is not matched by comparable criticisms of Fanon: that the latter starts from, and then revises, the "master-slave" trope is taken as a matter of course. 
certain strands of psychoanalytic thinking, certain psychoanalytically-based arguments, that are unpopular today. Like Beauvoir, he does so in order to use psychoanalytic tools of description and analysis, while refusing the teleology that would keep every problem on an individual level, as the unfolding of an individual story.

The task Fanon set himself was, as I said, one of demystification:

White civilization and European culture have imposed on the Black an existential deviation. We shall demonstrate elsewhere that often what people call the Black soul is a white construction. ${ }^{274}$

We here indict both those who have been swindled and those who swindled them ... [There are] a certain number of realities to whose liquidation we wish here to contribute. ${ }^{275}$

Unlike many of his day, he does not plan to do this by making a case for the value of Black culture or the full humanity of people of color.

Oh yes, as we see, by appealing to humanity, to a sense of human dignity, to love, to charity, it would be easy for us to prove, or to win the admission, that the Black is the equal of the white. But our goal is quite different: to help the Black man to free himself of the arsenal of complexes that has sprouted up from the colonial situation. ${ }^{276}$

But as Gwen Bergner cogently puts it, "[t]he difficulty is to recognize the psychic damage caused by racism without representing oppressed minority subject positions as essentially compromised."277 Fanon thus describes his project

274 "La civilisation blanche, la culture européenne ont imposé au Noir une déviation existentielle. Nous montrerons ailleurs que souvent ce qu'on appelle l'âme noire est une construction du Blanc" (PNMB $11 ; B S W M$ 6, translation altered).

275 "Nous faisons ici le procès des mystifiés et des mystificateurs" ... "un certain nombre de réalités à la liquidation desquelles nous voulons ici contribuer" (PNMB 25; BSWM 19-20, translation altered).

276 "Oui, comme on le voit, en faisant appel à l'humanité, au sentiment de la dignité, à l'amour, à la charité, il nous serait facile de prouver ou de faire admettre que le Noir est l'égal du Blanc. Mais notre but est tout autre: c'est aider le Noir à se libérer de l'arsenal complexuel qui a germé au sein de la situation coloniale" (PNMB 24; BSWM 19, translation altered).

277 Gwen Bergner, "Politics and Pathologies: On the Subject of Race in Psychoanalysis," 223. Fanon is clear in his disdain for the sort of psychoanalysis that concludes by proving to man "that he is nothing"; the problem will have to be proposed carefully, and differently (PNMB 17-18, BSWM 12). 
both as a "procès" (a case at law, an indictment) and as a "sociodiagnostique." Psychology does not unfold in a vacuum.

Before the trial opens, we must insist on a few points. The analysis we undertake is psychological. It remains nonetheless evident that for us the true disalienation of the Black implies an abrupt bringing-to-consciousness of social and economic realities. If there is an inferiority complex, it is the outcome of a double process:

-first, economic;

- subsequently by interiorization or, to say it better, epidermalization, of this inferiority.

Reacting against the constitutionalist school of the late nineteenth century, Freud, through psychoanalysis, insisted that the individual factor be taken into account. He substituted an ontogenetic perspective for the phylogenetic theory. As we shall see, the Black man's alienation is not an individual question. As well as phylogeny and ontogeny, there is sociogeny. ${ }^{278}$

Fanon's terms- "sociogénie," "sociodiagnostic" —seem reasonable descriptors also for the project of The Second Sex, with its ultimate refusal to choose between (a modified version of) Marx and (a modified version of) Freud.

The concept of a Black "inferiority complex," which Fanon uses as a jumping off point, is drawn from the work of "Professor Westerman"279 and especially from Octave Mannoni; his chapter 4, "Du prétendu complexe de dépendance du colonisé" (On the So-Called Dependency Complex of Colonized Peoples) is an epic takedown of Mannoni's study of Madagascar, Psychologie de la colonisation. Where Mannoni thought he saw a Black "inferiority complex"

278 "Avant d'ouvrir le procès, nous tenons à dire certaines choses. L'analyse que nous entreprenons est psychologique. Il demeure toutefois évident que pour nous la véritable désaliénation du Noir implique une prise de conscience abrupte des réalités économiques et sociales. S'il y a complexe d'infériorité, c'est à la suite d'un double processus:

-économique d'abord;

- par intériorisation ou, mieux, épidermisation de cette infériorité, ensuite.

Réagissant contre la tendance constitutionnaliste de la fin du XIX $x^{\mathrm{e}}$ siècle, Freud, par la psychanalyse, demanda qu'on tînt compte du facteur individuel. À une thèse phylogénétique, il substituait la perspective ontogénétique. On verra que l'aliénation du Noir n'est pas une question individuelle. À côté de la phylogénie et de l'ontogénie, il y a sociogénie" ( $P N M B$ 8; BSWM 4, translation altered). 
that supposedly predated colonialism, Fanon saw the psychic effects of the colonial situation itself: "[i]t is the racist who creates his inferior." 280

[W]hy does [Mannoni] try to make the inferiority complex something that existed before colonization? We recognize here the explanatory mechanism that, in psychiatry, would yield: there are latent forms of psychosis that manifest following a trauma. Or, in surgery: the appearance of varicose veins in a certain individual does not arise from his being compelled to spend ten hours a day standing up, but really from a constitutional weakness in the walls of his veins; his working conditions are only a facilitating factor. And the insurance compensation expert to whom the case is submitted will find the responsibility of the employer extremely limited. ${ }^{281}$

Fanon makes short work of Mannoni's apologetics, and his claim that French colonialism was somehow "less racist" than other countries; he reanalyses Mannoni's data (including the dreams of children) in the light of the real massacres that conditioned the fear Mannoni described.

What must be done is to restore this dream to its proper time, and this time is the period during which eighty thousand natives were killedthat is to say, one of every fifty persons in the population; and to its proper place ...282

The Senegalese soldier's rifle is not a penis but in truth a model 1969 Lebel rifle. ${ }^{283}$

280 "[C]'est le raciste qui crée l'infériorisé" (PNMB 75, BSWM 69).

281 "[P]ourquoi veut-il faire du complexe d'infériorité quelque chose de préexistant à la colonisation? Nous reconnaissons là le mécanisme d'explication qui, en psychiatrie, donnerait: il y a des formes latentes de la psychose qui deviennent manifestes à la suite d'un traumatisme. Et en chirurgie: l'apparition de varices chez un individu ne provient pas de l'obligation pour lui de rester dix heures debout, mais bien d'une fragilité constitutionnelle de la paroi veineuse; le mode de travail n'est qu'une condition favorisante, et le surexpert requis décrète très limitée la responsabilité de l'employeur" (PNMB 68-9; BSWM 62-3, translation altered).

282 "Il s'agit de replacer ce rêve en son temps, et ce temps c'est la période pendant laquelle quatre-vingt mille indigènes ont été tués, c'est-à-dire un habitant sur cinquante; et dans son lieu" (PNMB 84, BSWM 70).

283 "Le fusil du tirailleur sénégalais n'est pas un pénis, mais véritablement un fusil Lebel 1916" (РNMB 86; BSWM 79, translation altered.) 
Fanon then juxtaposes to Mannoni's dream accounts a long and devastating excerpt from a trial document, detailing torture at Tananarive. (Note his use, like Beauvoir's, of long quotations from original material; summary cannot do justice to the effect this is meant to have, and does have, on the reader. No, we will not be permitted to look away from this, from the real.) ${ }^{284}$

I see Fanon's de-Freudianized Freud as a darker version of Beauvoir's insistence that what little girls "envy" is not the penis, but the whole sphere of human activity that is denied to them because they don't have one. Like her, he rejects psychoanalytic "explanations" when real explanations will do. Just as it's useless to wonder why a woman "imagines" that birds are attacking her when birds really are attacking her, why women fear rape when the threat of rape is all around them, one need not wonder why a Black man would dream of becoming white in a culture that ceaselessly affirms to him that white culture is superior and that he can achieve nothing. The purchase of this on today's problems should be clear: it makes no more sense to blame students of color for their lack of "resilience" than to blame their elders for their high blood pressure. ${ }^{285}$ The same is true for the trauma of rape, and of the constant threat of rape that hangs in the air, and of the existential hatred directed at non-ideal female bodies (which is to say, at female bodies tout court). ${ }^{286}$ Nonetheless, the damage done is manifest, and it is urgent not to pretend it away, but to seek or invent a therapeutic, one component of which must somehow involve an activist awareness that goes beyond the individual. ${ }^{287}$

Another parallel to Beauvoir: Fanon's appropriation of psychoanalysis is eclectic, and some of the authorities he cites are not household names. People tend to notice his occasional mentions of Lacan. But the Lacan cited by both Beauvoir and Fanon was not yet Lacan with a capital L: both the power plays by which he and his followers would come to dominate the institutions

284 See Nigel Gibson, “Losing Sight of the Real: Recasting Merleau-Ponty in Fanon's Critique of Mannoni."

285 And yet both are done, explicitly or implicitly, a tradition going back to Moynihan and well beyond.

286 See Fiona Vera-Gray, Men's Intrusion, Women's Embodiment. And of course some people experience both simultaneously and synergistically, as Tamara Beauboeuf-Lafontant has shown.

287 "What emerges then is the need for a combined action, on the individual and on the group. As a psychoanalyst, I should help my patient to conscientize his unconscious, to stop seeking a hallucinatory lactification, but rather to take action toward changing the social structures." [Ce qui apparaitt alors, c'est la nécessité d'une action couplée sur l'individu et sur le groupe. En tant que psychanalyste, je dois aider mon client à conscientiser son inconscient, à ne plus tenter une lactification hallucinatoire, mais bien à agir dans le sens d'un changement des structures sociales ( $P N M B$ 80; BSWM 74 , translation altered).] 
of French psychoanalysis, and the uptake by Americans that would make him the darling of (Anglo-American) "French theory," lay in the future. ${ }^{288}$ Lacan appears in both their texts as one among many authorities, and not the most interesting. Rather, we encounter names no one knows today, but whose work is indeed more appropriate, or at least more productive and open for appropriation. In Fanon's text, one is the Swiss Charles Odier:

Man's tragedy, Nietzsche said, is that he was once a child. None the less, we cannot afford to forget that, as Charles Odier has shown us, the neurotic's fate remains in his own hands. ${ }^{289}$

Another is Germaine Guex, whose work he cites copiously in the analysis of the neurotic Jean Veneuse (the hero of a novel by René Maran), which constitutes the second part of his chapter "L'homme de couleur et la blanche" (The Man of Color and the White Woman). ${ }^{290}$

Who was Germaine Guex?

Germaine Guex was a Swiss psychoanalyst who rose briefly to prominence with a $195^{\circ}$ book called La névrose d'abandon, later reissued as Le syndrome d'abandon. She wrote it in isolation, during the war; she was married to Odier, and worked as a research assistant to Jean Piaget. The book describes a neurosis that differs from, has been absent from, classical Freudian accounts because it does not derive from the repression that arises from the Oedipus complex; rather, it stems from a pre-Oedipal lived "vécu" involving abandonment (real or imagined), a "vécu" which has not been worked through (and thus continues to recur), but has also not been repressed. The memories are thus consciously available to the patient, not just as memories, but as if they were happening now, with disastrous consequences for the patient's conduct of his or her present life. ${ }^{291}$

288 See Élisabeth Roudinesco, Histoire de la psychanalyse en France, and David Macey, Lacan in Contexts.

289 "Le malheur de l'homme, disait Nietzsche, est d'avoir été enfant. Toutefois, nous ne saurions oublier, comme le laisse entendre Charles Odier, que le destin du névrosé demeure entre ses mains" (PNMB 8; BSWM 4).

290 Another way Fanon follows Beauvoir is in his seamless uptake of literary example as if it were "clinical evidence" - though of course Freud did this too.

291 'We will use the term 'abandonnique' to refer to the neurotic who sees everything and everyone, beginning with himself, from the point of view of the abandonment he experienced, or dreads." [Abandonnique signifiera le névrosé qui envisage tout et tous, à commencer par lui-même, du point de vue de l'abandon vécu ou redouté (Germaine Guex, $L e$ syndrome d'abandon, 19).] 
Guex seems to have been concerned less with theoretical innovation than with compassionate and effective treatment for those whom a more conventional treatment had failed to help; there is some similarity between her ideas and those of Donald Winnicott, Jeanne Lampl de Groot, perhaps Melanie Klein; but (apart from her use by Fanon) the book was, from the point of view of intellectual history, a dead end. ${ }^{292}$ However, when the book came out it was a bestseller; it would appear that many people recognized themselves in this portrait, including many who had already undergone a traditional psychoanalysis, even become analysts themselves, but were still unhappy. I am tempted to compare it to Alice Miller's book, The Drama of the Gifted Child, which was similarly popular with a lay audience, and which also calls for a more compassionate psychoanalytic practice, as from one human being to another. ${ }^{293}$ Perhaps one reason Guex's book had so little lasting impact was that Jacques Lacan disliked it very much. He commented to a seminar in 1958:

The tremendous popularity of the "névrose d'abandon" has been not so much due to the young analysts as to certain sick people, who use it to prop up their neurotic-delusional claims. ${ }^{294}$

Part of what was a lightbulb for some and a professional red flag for others was Guex's view that there was no point in seeking the source of neurosis in unconscious repression of experiences - the patient was aware of them already: indeed, ceaselessly ruminating on his childhood abandonment is a key symptom, along with a complete "lack of self-esteem," crippling anxiety, "a sharp sense of catastrophe," and an affective "avidity" and "aggression" that stem from a

292 Or almost: Reiner Stach mobilizes Guex's description of the "abandonnique" quite convincingly in his recent biography, Kafka: The Early Years (71-4).

293 While ordinary readers found both books helpful in understanding their own histories and conditions, neither book was written to be "used" in that way: they are addressed very much to the practitioner.

294 "Le grand succès de la névrose d'abandon n'est pas tellement auprès des jeunes analystes que chez certains malades qui y trouvent un support pour leur revendication névroticodélirante" (Lacan, "Interventions sur l'exposé de J. Favez-Boutonnier: Abandon et névrose, Société Française de Psychanalyse," 3). René Henny, writing the introduction to the 1973 edition, was almost as hostile: "How many patients have been led to psychotherapy by a naïve reading of this book? And, indeed, it does not leave one unmoved." [Combien de patients n'ont-ils pas été conduits à la consultation psychothérapique par la lecture naïve de ce livre? Il ne laisse en effet pas indifférent" (9).] He notes that it was a "great success in the bookstores, which is probably why the publishers have insisted on a new edition in spite of the author's reticence." [[U]n succès de librairie, d'où probablement l'insistance de l'éditeur à une nouvelle édition, en contrepoint de la réticence de l'auteur (9).] 
chronic state of fear. ${ }^{295}$ The patient's inability to trust anyone results in conduct that alienates others, "proving" that he was right all along. Therefore the neurosis must be treated, as she puts it, "dans le vrai" (in the real), by careful attention to "le vécu," what is lived: a classically abstinent analysis, where the doctor shows no emotional connection with the patient, will be counterproductive. As she says, the task is delicate, and if following Fanon one adds politics to this it becomes even more delicate: not to deny the real roots of historical and ongoing trauma (what really happened, really did happen) but yet to move forward, without imposing a new set of ideological mystifications ... not to dismiss the manifestations of trauma as (individual) "neurosis" and yet, to find a way forward for those who are in pain ... to undertake the urgent work of repair without promising a cure that it is not in the power of therapists or teachers to give ... to find a way that does not require not listening to what people actually say, or assuming that one knows them better than they know themselves. (David Macey cites Fanon's later mentor François Tosquelles: “Useless to offer psychotherapy to a dead man, it's too late. Useless also to interpret his oral fixation to someone who is hungry, or his castration complex to a man with a wooden leg."296) This is very much related to the problem Anne Dubreuilh

295 "[N]on-valorisation de soi," "un sens aigu de la catastrophe," "état chronique de peur" (Guex, Le syndrome d'abandon, 47). "Affective non-valorization always leads the abandonnique to an extremely painful and obsessive feeling of exclusion, of being at home nowhere and unwanted everywhere, affectively speaking. The need to belong, a primary deep need of every human being, has remained unsatisfied since infancy, because the subject did not feel strongly connected to someone, a mother or father whose love was lacking, nor really integrated to the family milieu. Since then, the subject has generally stood apart from any real affective tie or milieu, believing himself excluded by others, but in truth excluding himself, whether from a feeling of unworthiness, or on account of his many fears. Mistrust, aggressiveness, and passivity combine with lack of self-esteem to impose on the abandonnique a severely restricted reserve." [La non-valorisation affective amène toujours l'abandonnique à un sentiment extrêmement pénible et obsédant d'exclusion, de n'avoir nulle part sa place, d'être de trop partout, affectivement parlant. Le besoin d'appartenance, besoin primaire et profond chez tout être humain, est demeuré insatisfait dès l'enfance, du fait que le sujet ne s'est pas senti fortement lié à tel être, mère ou père, dont l'amour lui à fait défaut, ni réellement intégré au milieu familial. Dès lors, le sujet est généralement resté en dehors de tout lien ou de tout milieu réellement affectif, se croyant exclu par les autres, mais en fait s'excluant lui-même, tant par sentiment d'indignité, que sous l'effet de peurs multiples. Méfiance, agressivité et passivité se joignent à la non-valorisation pour interdire à l'abandonnique de sortir d'un quant-à-soi sévèrement protégé (ibid., 45).]

296 "Inutile de faire de la psychothérapie à un mort, c'est trop tard. Inutile aussi d'interpréter son oralité à quelqu'un qui a faim, ou son complexe de castration à l'homme qui a une jambe de bois" (Macey, “Adieu Foulard," 25.) 
confronts in her therapeutic practice at the start of Les mandarins, and it emerged from the same experiences of wartime displacements, dislocations, real-world tragedies.

I think it must be the insistence on "le vécu," on addressing the neurotic's problems in the here and now, that appealed to Fanon in Guex's work; she herself is not concerned in the least with racial politics, or any other kind, ${ }^{297}$ but Fanon seems to have found the combination of Guex and Maran useful for thinking through his own subject position and that of the Black man in a white world more generally. ${ }^{298}$ Guex believes in what she calls a "constitutional" factor in neurosis, which leads her to caution against blaming parents. (This seems to be a big reason why the mainstream of psychoanalysis set her work aside. $)^{299}$ But Fanon found it a productive view.

There can be no argument: in the domain of psychoanalysis as in that of philosophy, the organic, or constitutional, is a myth only for him who can go beyond it [celui qui la dépasse]. If from a heuristic point of view one must totally deny the existence of the organic constitution, the fact remains, and we can do nothing about it, that some individuals insist on belonging to pre-established categories. Or, no, actually we can do something about it. 300

297 Some of Guex's descriptive analyses are reminiscent of Beauvoir's, as when she remarks that apparent devotion to someone else may become a form of tyranny, or when she says that "one could write a whole book about the relationship between mistresses and their maid." [Il y aurait une volume à écrire sur les relations des maîtresses de maison avec leur bonne (Guex, Le syndrome d'abandon, 55).] But according to Guex the névrose d'abandon affects women and men alike, in quite similar ways.

298 Insofar as I can tell, Guex and Odier's work seems refreshingly free of Lacan's smug normative assumptions about the inevitability of heterosexuality and a specific content for "femininity" that remains tied to woman's maternal function (and I use the word "function" advisedly). See Judith Butler, "Lacan, Rivière, and the Strategies of Masquerade" ("Lacanian theory must be understood as a kind of slave morality," 76), and Eribon, Réflexions sur la question gay. But there is no indication that Fanon cared about any of that.

299 Lacan phrased his substantive objection as follows: "It is dangerous to foreground the real distinction - this critique of object relations implies the notion of a missing object for a being who lives in the symbolic and the real." [À mettre au premier plan la distinction réelle - cette critique de la relation à l'objet implique la notion de manque d'objet chez un être qui vit dans le symbolique et le réel—cela est dangereux.] Anglo-American practitioners like D. W. Winnicott and Melanie Klein would also do that, but their work led toward, rather than away from, the policing of maternal affect and behavior still visible today in the school of "attachment parenting." It's hard not to think this has something to do with the continuing visibility of their names when Guex has faded into oblivion.

300 "Il faut en convenir: sur le plan de la psychanalyse comme sur celui de la philosophie, la constitution n'est mythe que pour celui qui la dépasse. Si d'un point de vue heuristique on 
We referred earlier to Jacques Lacan; it was not at random. In his thesis, presented in 1932, he made a violent critique of the idea of organic constitution. Obviously, we are departing from his conclusions, but our dissent will be understood when one recalls that for the idea of the constitutional as it was understood by the French school we are substituting that of structure, "embracing unconscious psychic life, as we are able to know it in part, especially in the form of repression and inhibition, insofar as these elements take an active part in the organization peculiar to each psychic individuality." [He's quoting Guex's definition here.] ... The neurotic structure of an individual is simply the elaboration, the formation, the eruption within the ego, of conflictual clusters arising in part out of the environment and in part out of the purely personal way in which that individual reacts to these influences. ${ }^{301}$

I must admit it is not entirely clear to me why a political psychoanalysis would want to hang on to the idea of a pre-given (individual) "constitution," and I am not entirely sure whether Markmann is right to interpret the term "constitution" as referring to an underlying organic substrate. But either way, the idea of "structure" here seems to be doing similar work to Beauvoir's idea of "situation," which includes both the body and the individual's social history. Fanon concludes that Veneuse/Maran's problems are not reducible to questions of race, whatever Veneuse himself may think. And thus his "fate" (as he sees it) is not in fact fateful or inevitable.

Where does this analysis lead us? To nothing short of proving to Jean Veneuse that in fact he is not like the rest. Making people ashamed of their existence, said Jean-Paul Sartre. Yes: teaching them to become aware of

doit dénier toute existence à la constitution, il demeure, nous n'y pouvons rien, que des individus s'efforcent d'entrer dans des cadres préétablis. Ou du moins, si: nous y pouvons quelque chose" (РNMB, 64-5; BSWM 58 , translation altered).

301 "Nous parlions tout à l'heure de Jacques Lacan: ce n'était pas un hasard. En 1932, il a, dans sa thèse, fait une critique violente de la notion de constitution. Apparemment, nous nous écartons de ses conclusions, mais l'on comprendra notre dissidence quand on se rappellera qu'à la notion de constitution au sens où l'entendait l'école française, nous substituons celle de structure, 'englobant la vie psychique inconsciente telle que nous pouvons partiellement la connaître, en particulier sous la forme de refoulé et de refoulant, en tant que ces éléments participent activement à l'organisation propre de chaque individualité psychique.' ... La structure névrotique d'un individu sera justement l'élaboration, la formation, l'éclosion dans le moi de nœuds conflictuels provenant d'une part du milieu, d'autre part de la façon toute personnelle dont cet individu réagit à ces influences" (PNMB 65; $B S W M 5^{8-9}$, translation altered). 
the potentials they have forbidden themselves, of the passivity they have displayed in just those situations where what is needed is to act like a splinter aimed at the heart of the world, to interrupt, when necessary, the heartbeat of the world, to shift the ruling system when it must be shifted, but in any case, and most assuredly, to stand up to the world. ${ }^{302}$

Another solution is possible, as we shall see. It implies a restructuring of the world. ${ }^{303}$

How to bring this about, Fanon does not (yet) say. But in the meantime, "those who recognize themselves will have taken a step forward." ${ }^{304}$

There is one important limit to the parallel I have been drawing between Beauvoir and Fanon: the solution Fanon later advocated, of violent collective struggle for liberation, is not available to women as a group acting on our own behalf. We may be glad about this, or we may be sorry, but this is, as Beauvoir saw and said in The Second Sex, the place where analogies between the oppression of women and all the other oppressions she puts it in parallel with break down. ${ }^{305}$ So we are left with the problem of how to structure a healthy self in an unhealthy world. I can't answer this question, either, but Gordon reads Fanon as saying that "the basic problem ... is to restore the humanity of each degraded person."306

302 “Àquoi tend cette analyse? À rien de moins qu'à démontrer à Jean Veneuse qu'effectivement il n'est pas pareil aux autres. Faire honte aux gens de leur existence, disait Jean-Paul Sartre. Oui: les amener à prendre conscience des possibilités qu'ils se sont interdites, de la passivité dont ils ont fait montre dans des situations où justement il fallait, telle une écharde, s'agripper au cœur du monde, forcer s'il le fallait le rythme du cœur du monde, déplacer s'il le fallait le système de commande, mais en tout cas, mais certainement, faire face au monde" (РNMB 63; BSWM 57, translation altered, emphasis in original).

303 "Nous verrons qu'une autre solution est possible. Elle implique une restructuration du monde" (PNMB 66; BSWM 6o, translation altered).

$304 \quad P N M B, 10 ; B S W M$ 5. "Ceux qui s'y reconnaîtront auront, je crois, avancé d'un pas."

305 Some of the reasons she gives for this might (at least in theory) be overcome by subsequent historical developments. That the "apprenticeship" girls receive conditions them to regard their bodies as passive rather than active instruments, that they are educated to be the victims rather than the agents of violence, perhaps might be addressed by providing different sorts of training; women's participation in athletics may already have made some difference here (see Vera-Gray, Men's Intrusion, Women's Embodiment). The necessity of heterosexual intercourse to perpetuate the race is no longer as fully a feature of "the real" as it was in 1949. But the argument I've been calling "intersectional" - that women's interests (real and perceived) often lie in greater solidarity with the men of their group, rather than with women as a transnational, transracial, transeconomic class for itself-seems likely to stand. This is a structural feature of the human world, not a mystification that can be overcome by thinking about it differently.

306 Gordon, What Fanon Said, 45. 
But wait a minute, you say: wasn't Frantz Fanon a terrible misogynist?

As with Wright, views (vehemently) differ. Amey Victoria Adkins is among those who think so. She connects Fanon's failure to acknowledge Beauvoir's intellectual contribution to what she calls "the categorically negative assessment of women in Black Skin, White Masks": his "acerbic rendering" of Mayotte Capécia's novel and her life in his chapter 2, "La femme de couleur et le Blanc" (The Woman of Color and the White Man), and in general the way he treats the bodies of women, white and Black, in describing the development of Black male subjectivity under conditions of racism. ${ }^{307}$

Many, many scholars have taken up this question, and a full consideration is impossible here. ${ }^{308}$ But putting Fanon into parallel with Beauvoir, as Adkins suggests we do, can help us see that these two chapters in Peau noire masques blancs - "La femme de couleur et le Blanc" and "L'homme de couleur et la Blanche"-are meant to be phenomenological accounts, and accounts of neurosis, of the way relations between men and women and between Blacks and whites are deformed and twisted by racism, and by the tendency for the colonized to accept the values of the colonizer. Considering that the book is an attack on racism, a surprisingly large number of pages are consumed in unflattering portraits of people of color, both female and male; many readers also had trouble seeing The Second Sex as a feminist book because so many of the women portrayed there are frankly so horrible. But that is precisely the point: for Beauvoir, as I wrote above, the harmed person could not be good; for Fanon-perhaps for both of them?- the harmed person could not be well.

Fanon denounces Mayotte Capécia for her complicity with whites in a way that strikingly recalls Wright's unhappiness with Zora Neale Hurston. And T. Denean Sharpley-Whiting makes a point similar to what Hazel Carby said about Hurston: we should ask why Capécia's (otherwise unacclaimed) novel Je suis martiniquaise was awarded the Grand Prix littéraire des Antilles in 1949 by a jury composed of thirteen white Frenchmen, and why Euro-American "lit crit feminists" (as she describes them) have leapt to her defense. ${ }^{309}$

307 Adkins, "Black/Feminist Futures," 701, 699.

308 See Gwen Bergner, Taboo Subjects: Race, Sex, and Psychoanalysis, T. Denean SharpleyWhiting, Frantz Fanon: Conflicts and Feminisms, and Françoise Vergès, "Chains of Madness, Chains of Colonialism: Fanon and Freedom."

309 Sharpley-Whiting, Frantz Fanon, 36. 
To reconstruct Capécia's story as an example of Black feminism in practice because she is a Black woman and was taken to task by Fanon is, to say the least, a dangerous feminist politics. One has to ask equally what is invigorating about Capécia's representations and for whom are they invigorating? $?^{310}$

Sharpley-Whiting suggests that "many Euro-American lit crit feminists have not read Capécia's novels, but only one another's writing on Fanon and Capécia."311 I am not sure whether this is fair, but it is certainly the case that Fanon's "attack" on Capécia, like Wright's "attack" on Hurston, have passed into, and been passed around in, the secondary literature almost as a decontextualized "topos" with little or no connection to what either writer actually said. (Perhaps this is a parallel to what I called above the "Spelman moment" in feminist reception of Beauvoir.)

Mayotte's story is only one of the strands in "La femme de couleur et le Blanc." Fanon is equally scathing about Nini, the heroine of a novel by Aboulaye Sadji, a male Senegalese writer. He also weaves in real-world examples from everyday life in Martinique, and in Paris, such as a young woman student of color (she will one day be a teacher in the Antilles), who finds Césaire's activism distasteful and could not imagine marrying a "nègre." 312 The issue for Fanon is not so much that Capécia's and Sadji's heroines, and their real-life counterparts, are women, but that they are sell-outs, that the social sickness of colonialism has had its way with them. This is visible in Mayotte's desire to be white, in her desire to marry a white man in order to "magically whiten" herself. Mayotte's story-or at least, the story she tells in her books-enables Fanon to explain lucidly how "métissage" in Martinique is not one phenomenon but two, depending on whether it is the father or the mother who is white. ${ }^{313}$

Gordon remarks, "it is unclear to me how Fanon is expected to have written on the two main accounts of women of color, Capécia's and A. Sadji's, without the criticisms he has offered as part of his ongoing argument." ${ }^{314}$ And he continues:

310 Ibid., 49. Fanon: "the enthusiastic reception that greeted this book in certain circles forces us to analyze it." [L'accueil enthousiaste qui a été réservé à cet ouvrage dans certains milieux nous fait un devoir de l'analyser ( $P N M B$ 34, BSWM 29).]

311 Sharpley-Whiting, Frantz Fanon, 19.

$312 \quad$ PNMB 38, BSWM 33.

313 PNMB 37, BSWM 32.

314 Gordon, What Fanon Said, 29. 
Fanon announced that he was examining pathological cases, those of the phobic and the failure.... I do not see Black (especially Martinican) men faring especially well who return to the Antilles to be "deified," deluded foragers of civilization in a pair of "white breasts," pathetic slaves in search of whiteness through, if not white women, at least mulattas who condescendingly offer a bit of whiteness, and so on. ${ }^{315}$

Gordon's defense of Fanon on Capécia is plausible to me-Fanon is describing a case of bad faith, of pathological narcissism. This is not the only possible reading of Je suis martiniquaise, but it is a credible one.

"One day a woman named Mayotte Capécia, obeying a motivation whose elements are difficult to detect, sat down to write two hundred and two pagesher life-in which the most ridiculous ideas proliferated at random." ${ }^{316}$ Fanon's is certainly a negative review (though perhaps not unusually nasty, by French standards). However, having read the book, I do not find Fanon's description unfair:Je suis martiniquaise is a simple, straightforward narrative of what the main character (who is given the same name as the author) experienced, and how she felt about it at the time, with no reflection of any sort, and it is indeed "difficult to detect" why it was written or what its author may have been, as the students put it, "trying to say." What Capécia does say, in an entirely straightforward manner, is that Black men and women are ugly, that white men and women are superior objects of desire, that she wants to be whiter and marry a white man, and that she can't. Reading it made Fanon angry. It might make us sad instead, as Sharpley-Whiting suggests. ${ }^{317}$ But he doesn't misrepresent it. Similarly, in Capécia's La négresse blanche, it is clear that the heroine fears and is disgusted by Blackness, in herself and others. One can think of some twentieth-century texts by Black women that riff on the received trope of the "tragic mulatto" in fascinating and productive ways-Nella Larsen's Quicksand, for example. But Capécia simply recites that old story, without comment or complexity.

Fanon's reading of Capécia is certainly no further off the mark than his reading of René Maran, whose novel is mined in "L'homme de couleur et la Blanche"

\footnotetext{
315 Ibid., 30.

316 "Un jour, une femme du nom de Mayotte Capécia, obéissant à un motif dont nous apercevons mal les tenants, a écrit deux cent deux pages—sa vie—où se multipliaient à loisir les propositions les plus absurdes" (PNMB 34, BSWM 29).

317 Sharpley-Whiting, Frantz Fanon, 41.
} 
for the portrait of a perfectly neurotic man, unable to love. ${ }^{318}$ Moreover, literary criticism as such was not Fanon's aim. He also wasn't interested in proving that writers of color were good writers; in fact, the project of showing whites the excellence of Black achievements seemed to him a flawed project in itself. If the criticism is that Peau noire masques blancs is largely an investigation of colonized masculinity, well, yes it is. ${ }^{319}$ But the story it tells is not a happy one. The late section called "The Negro and Recognition" (Le Nègre et la reconnaissance) shows us men who are constantly comparing themselves to others, preoccupied with "autovalorisation," putting others down. The point of the section is to disprove Alfred Adler's "inferiority complex" theory by showing that this behavior is not related to an individual ego "goal," but is socially conditioned. Still, it's an unflattering portrait, and it's easy to see why Fanon says

318 See Sharpley-Whiting: "Fanon spreads his critical analysis of blackphobia rather evenly among male and female colonized subjects" (ibid., 11). "What 'sympathetic' tenor rings out in Fanon's observation that 'Jean Veneuse ... is a beggar. He looks for appeasement, for permission, in the white man's eyes'; or 'Un homme pareil aux autres is a sham, an attempt to make the relations between two races dependent on an organic unhealthiness'; and better still, in embarking upon uncovering Veneuse's complex neurosis, Fanon offers: 'Veneuse is the lamb to be slaughtered. Let us make the effort'?" (ibid., 48, quoting $P N M B$ 76, $80,66)$.

I might add that one feature of Veneuse's illness Fanon denounces is that he asks permission of a white male friend before approaching a white woman, who has shown considerable agency already in expressing her interest in him. Does this not at least sketch a proto-feminist critique of the exchange of women between men?

319 See Traci West, "Extending Black Feminist Sisterhood in the Face of Violence: Fanon, White Women, and Veiled Muslim Women." I agree with those who have written that the passages about the breasts of the white woman as source of the Black man's ego-salvation, which may owe something to Beauvoir's description of what men seek when they see woman as the Absolute Other, are hard to take, as is his depiction of the white woman who half incites the rape she fears. But whether they are hard (for me) to take is beside the point: making me (or anybody) comfortable is not Fanon's aim. As for the white woman who "cries rape," this is a topos common to a great deal of anti-racist writing, from Chester Himes's If He Hollers Let Him Go to Gwendolyn Brooks's “The Ballad of Pearl Mae Lee," and the primal scene of a rape accusation is clearly central to the psychology of Black masculinity in the twentieth century, at least as it is expressed in literature. (I am thinking of the scene in Ellison's Invisible Man [141-42] where the protagonist, newly arrived in the North, finds himself standing in the subway, and holds desperately on to his lapels to avoid inadvertently touching any of the white women he sees around him.) Two early Alice Walker essay/stories, "Coming Apart" and "Advancing Luna-and Ida B Wells," explore this dynamic beautifully: the narrator of "Advancing Luna" may partly be responding to Fanon and Wright when she says to herself, enraged, "Who know what the Black woman thinks of rape? Who has asked her? Who cares?" (93). Sharpley-Whiting: "We are here speaking of white women whose psychosexualities have been corroded, abnormalized, which in turn incite the cultural mythology of the Black male rapist, the sexually voracious Black brute" (Frantz Fanon, 13). 
several times that many of his compatriots would not recognize themselves. But he also says that those who did recognize themselves would have taken a step forward. ${ }^{320}$ I find myself thinking of Alice Schwarzer's comment that Beauvoir "gave women an explanation, but never an excuse."321

Fanon's phenomenological account of inter-racial relationships is not meant to imply that the behavior he describes is universal or inevitable, still less that he endorses the "male" version he describes in "L'homme de couleur et la Blanche."

Just as there was a touch of fraud in trying to deduce from the behavior of Nini and Mayotte Capécia a general law of the behavior of the Black woman with the white man, there would be, we maintain, a breach of objectivity in expanding the attitude of Veneuse to the man of color as such. ${ }^{322}$

This feels very similar to what Beauvoir was doing in her discussion of "myths," and it has been misunderstood in parallel ways. The ultimate goal is demystification, to stop believing lies, lying to oneself, lying to others. But to get there, Fanon, like Beauvoir, passes through an exploration of how powerful these myths are and how they are powerful. It's not an argument that they are inevitable, much less that they are desirable. To say that a desire is not desirable is not to stop desiring it. But it's a step. ${ }^{323}$

I wrote above about readers of Beauvoir experiencing a shock of recognition, and sometimes a shock of non-recognition. But suppose sometimes those shocks are simultaneous, or nearly? "I am not that ... I do not want to be that ... I am that ... I do not want to be that any more." In early 1970s consciousnessraising groups, this last stage was called, "starting to stop." ${ }^{324}$

\footnotetext{
$320 \quad P N M B$ 10, BSWM 5.

321 "Notre propos étant la désaliénation des noirs" ( $P N M B$ 30, BSWM 25).

322 "De même qu'il y avait une tentative de mystification à vouloir inférer du comportement de Nini et de Mayotte Capécia une loi générale du comportement de la Noire vis-à-vis du Blanc, il y aurait, affirmons-nous, manquement à l'objectivité dans l'extension de l'attitude de Veneuse à l'homme de couleur en tant que tel" ( $P N M B$ 65; BSWM 59, translation altered).

323 Sandra Bartky's early essays (reprinted in Femininity and Domination) work this through in ways I find illuminating.

324 Where Fanon says, "notre propos est la désaliénation des Noirs," could one describe Beauvoir's "propos" as "la désalienation des femmes"? She does not say so. In fact, she never says what her political project is, I think because she was discovering it along the way. The parallel I am describing here is between his intention and her effect.
} 
But there is another possibility: I am not that; thank God I am not like those women; yes, she really has their number; thank God there are other ways than that to be a woman. And in that respect both books are written from (and for) the subject position of the évolué, the colonized subject who has a greater understanding of the colonial situation than most of his brothers and sisters (so to speak); his or her first impulse will be to escape, and Fanon devotes a great deal of derisive energy to showing that this is impossible. (His mockery of the Martiniquais who returns from France with his nose in the air has its counterpart in Suzanne Césaire's contempt for the "vanilla" poets who stand in need of surrealist cure: in "Malaise d'une civilisation" she compared the évolué who is bent on assimilating to a "hysteric who does not know he is merely imitating a sickness, but the doctor does know.") ${ }^{325}$ The évolués first task as a political being must be to awaken his compatriots to a consciousness of the degradation in which they live but which they themselves do not "speak," even in their hearts. He or she begins by distinguishing him/herself from the character to which most of those who share his oppression have been reduced by their situation, including their intellectual and moral condition, and there is an inevitable moment of alienation for him or her, partly because his or her "evolution" has been enabled by his or her own colonization, through education directed from and by the metropole. Then too, he must resist racist assumptions that Blacks who are more "similar" to whites (either because they are educated, because they are more light-skinned, or both) are somehow more "evolved" in the sense of biologically superior: it is for this reason that Fanon sometimes puts "évolué" in quotation marks. (But sometimes he does not.)

White civilization and European culture have imposed on the Black an existential deviation. We shall demonstrate elsewhere that what people call the Black Soul is a white construction.

The évolué Black, slave of the spontaneous and cosmic Negro myth, feels at a given stage that his race no longer understands him.

Or that he no longer understands it. ${ }^{326}$

325 Suzanne Césaire, "Malaise d'une civilisation," 122.

326 "La civilisation blanche, la culture européenne ont imposé au Noir une déviation existentielle. Nous montrerons ailleurs que souvent ce qu'on appelle l'âme noire est une construction du Blanc.

Le Noir évolué, esclave du mythe nègre, spontané, cosmique, sent à un moment donné que sa race ne le comprend plus.

Ou qu'il ne la comprend plus" ( $P N M B 11 ; B S W M 7$, translation altered). 
And yet, if escape is impossible, nostalgia is worse. One cannot go backwards. The passage continues:

Then he congratulates himself on this, and enlarging the difference, the incomprehension, the disharmony, he finds in them the meaning of his real humanity. Or more rarely he wants to belong to his people. And it is with rage on his lips and vertigo in his heart that he buries himself in the vast Black abyss. We shall see that this attitude, so absolute and beautiful, renounces the present and the future in the name of a mystical past. ${ }^{327}$

Throughout Peau noire masques blancs, Fanon carries on a debate with other Black intellectuals (the most prominent being the poet Léopold Senghor), who were advocating a sort of Afrocentric celebration of Blackness, a re-valorization of what white culture had devalued, leaning on cultural difference as a springboard to liberation, under the banner of "négritude." I think Max Silverman is right to say that "Fanon's position oscillates between intellectual critique and emotional empathy," but ultimately, he is just not with them. ${ }^{328}$ For one thing, he is very aware of cultural differences between groups that would all be considered "Black," and of racist tensions between, for example, the Antillais and the Sénégalais - tensions for which the white colonizers are ultimately responsible, and which they exploit shamelessly, but which are nonetheless real. ${ }^{329}$ While his desire for solidarity across national boundaries comes

327 "Alors il s'en félicite et, développant cette différence, cette incompréhension, cette désharmonie, il y trouve le sens de sa véritable humanité. Ou plus rarement il veut être à son peuple. Et c'est la rage aux lèvres, le vertige au cœur, qu'il s'enfonce dans le grand trou noir. Nous verrons que cette attitude si absolument belle rejette l'actualité et le futur au nom d'un passé mystique" ( $P N M B$ 11; BSWM 7, translation altered).

328 Silverman, New Interdisciplinary Essays, 3.

329 "One has had friends - and unfortunately one still does—who were born in Dahomey or the Congo but pretend to be natives of the Antilles; one has known, and one still knows, Antilleans who become annoyed when they are suspected of being Senegalese. This is because the Antillean is more 'civilized' than the Black African, in other words he is closer to the White; and this difference prevails not only in the street and on the boulevards but also in public service, in the army. Any Antillean who performed his military service in a regiment of sharpshooters is familiar with this disturbing situation: on one side he has the European, whether born in his own country or in France, and on the other he has the Senegalese marksmen. A day comes back to me when, in the midst of combat, it was a question of wiping out a nest of machine-guns. Three times the Senegalese were launched on attack, three times they were forced back. Then one of them asked, why don't the toubabs go? At such times, one ends up unsure which one is, toubab or indigène."

(Markmann has a translator's note about toubab: "Literally, this dialect word means European; by extension it was applied to any officer.") 
through in the text (and would become clearer in his later writing, and the commitments of his life), it is not a solidarity based on a clear, real, unambiguous identity.

This strikes me as yet another parallel to Beauvoir. Fanon is struggling here with Sartre's view that what Sartre calls an "anti-racist racism" will be a necessary stage of self-affirmation in moving toward an ultimately post-racialist future. Toril Moi describes him as brilliantly "manag[ing] at once to signal his distance from and endorsement of Sartre's positions," which perhaps entails an acceptance of the need for what would later be called "strategic essentialism." 330 Moi sees it as a "the deepest political flaw in The Second Sex" that Beauvoir did not make the corresponding move of affirming an "antisexist sexism,"331 but I can't quite agree: for one thing, Beauvoir's refusal to do so is what enables what I've been calling her intersectionality.

Fanon saw the négritude movement as invoking a concept of Blackness that was not just inaccurately monolithic, but too static, too closed, too unwilling to admit the dimensions of time and change: in short, insufficiently existentialist. He is scathing about what he later labels "folklore,"332 and about what he sees as pathetic attempts to convince Europeans that Africans, too, have a significant though "different" culture. In the case of Mannoni, he is clear that the idea of a Malagasy "culture" is a dangerous mystification:

After having locked up the Malagasy in his customs, after having carried out a unilateral analysis of his way of seeing the world, after having described the Malagasy within a closed circle, after having noted that the Malagasy maintains relationships of dependency with his ancestors-eminently tribal characteristics-M. Mannoni, in defiance of all objectivity, then

[Nous avons connu, et malheureusement nous connaissons encore, des camarades originaires du Dahomey ou du Congo qui se disent Antillais; nous avons connu et nous connaissons encore des Antillais qui se vexent quand on les soupçonne d'être Sénégalais. C'est que l'Antillais est plus "évolué" que le Noir d'Afrique; entendez qu'il est plus près du Blanc; et cette différence existe non seulement dans la rue et sur les boulevards, mais aussi dans les administrations, dans l'armée. Tout Antillais ayant fait son service militaire dans un régiment de tirailleurs connaît cette bouleversante situation: d'un côté les Européens, vieilles colonies ou originaires, de l'autre les tirailleurs. Il nous souvient de certain jour où, en pleine action, la question se trouva posée d'anéantir un nid de mitrailleuses. Par trois fois les Sénégalais furent lancés, par trois fois ils furent rejetés. Alors, l'un des leurs demanda pourquoi les toubabs n'y allaient pas. Dans ces moments-là, on arrive à ne plus savoir qui l'on est, toubab ou indigène ( $P N M B 20 ; B S W M$ 15, translation altered).] Moi, Simone de Beauvoir: The Making of an Intellectual Woman, 206.

331 Ibid., 211.

332 See "Sur la culture nationale" in Les damnés de la terre (195-224). 
applies his conclusions to the understanding between two groups-deliberately ignoring the fact that, since Galliéni, the Malagasy has ceased to exist. ${ }^{333}$

(This is more or less Leiris's critique of colonialist anthropology, most fully laid out in the 1950 lecture I discussed earlier, but already sketched in the essays Fanon cites in Peau noire masques blancs.) Fanon is equally critical, though, of Black writers like Alioune Diop who were advancing the idea of an alternative African metaphysics:

What use are reflections on Bantu ontology when one reads elsewhere: "When 75,00o Black miners went on strike in 1946, the state police forced them back to work by firing on them with rifles and charging with fixed bayonets. Twenty-five were killed and thousands were wounded."334

We know that Bantu society no longer exists. And there is nothing ontological about segregation. Enough of this rubbish. ${ }^{335}$

In a 1956 talk, he would describe the "zombification of culture": an effort to "freeze time" that was equally misguided whether undertaken as a strategy of colonization or a strategy of resistance. And his analysis that a woman wearing a veil can mean many different things, not just either "feudal" dependency or resistance to colonialism, his (unfortunately prescient) awareness of the limitations of Algerian nationalism, is rooted in this same dynamism of the évolué, who understands culture itself as dynamic. ${ }^{336}$

333 "Après avoir enfermé le Malgache dans ses coutumes, après avoir réalisé une analyse unilatérale de sa vision du monde, après avoir décrit le Malgache en cercle fermé, après avoir dit que le Malgache entretient des relations de dépendance avec les ancêtres, caractéristiques hautement tribales, l'auteur, au mépris de toute objectivité, applique ses conclusions à une compréhension bilatérale-ignorant volontairement que depuis Galliéni le Malgache n'existe plus" ( $P N M B$ 76; BSWM 69-70, translation altered). A note by Markmann explains that Galliéni, "the hero of the Marne," was appointed resident-general of Madagascar when it became a French colony in 1896, and later became governor-general. Markmann quotes the Encyclopedia Britannica: Galliéni "completed the subjugation of the island."

334 "Que signifient les méditations sur l'ontologie bantoue, quand on lit par ailleurs: 'Lorsque soixante-quinze mille mineurs noirs se sont mis en grève en 1946, la police d'État les a contraints à coups de fusil et à coups de baïonnette à reprendre le travail. Il y a eu vingtcinq morts, des milliers de blessés"' (PNMB 148-49, BSWM 142).

335 “[N]ous savons que la société bantoue n'existe plus. Et la ségrégation n’a rien d'ontologique. Assez de ce scandale" (PNMB 150, BSWM 143).

336 Fanon, "Racisme et culture"; "Mésaventures de la conscience nationale"; "L'Algérie se dévoile." 
In a situation where structural inequalities manifest themselves as social and cultural hegemonies, attempts to free oneself by understanding one's oppression often, maybe always? take place against the background of others who share the oppression but do not seem to have the same drive to understand and fight it. This is an important component of Richard Wright's Black Boy, of the Aimé Césaire poem from which Peau noire masques blancs draws so much of its energy and imagery, of the essays by Suzanne Césaire and others in Tropiques and Légitime défense. Wright finds Hurston's approach misguided; later, Baldwin will feel the same about Wright...

I see the same dynamic in Mémoires d'une jeune fille rangée and The Second Sex - the issue is not explicitly posed in The Second Sex, where Beauvoir is, as I have said, really not concerned with "identity" as such at all: but there is the same struggle to free the idea of "women" from what women and girls are told, often by women, they must or should be like, and from the reality of what many women around one are like. It is interesting that when Beauvoir did come to speak as a feminist, she was asked about this question of "we," and she described a kind of split subject- "when I say we I mean we feminists, not we women."337

The legacy of this structure for feminism has been something of a poisoned chalice, really. One consequence has been generational warfare; another has been a struggle around the term "feminist," both struggles to possess it (as in the sex wars, or the des femmes debacle), and struggles to disavow or/and relabel it ("power feminism," "womanism," etc.). None of these struggles have "succeeded," exactly, in the sense that no new label has "won" and feminism is owned by no one. But it does not seem entirely right, either, to describe these as unfortunate, divisive "splits in the movement." From the point of view of dialectics, the splits in the movement are the movement.

337 “A. S.—Avant l'existence du Mouvement, vous disiez 'elles' en parlant des femmes. Maintenant vous dites 'nous.' S. B. - Pour moi, cela ne signifie pas 'nous les femmes,' mais nous les féministes" (Schwarzer, Simone de Beauvoir aujourd'hui, 124). 